\title{
AVALIAÇÃO DO pH E LIBERAÇÃO DE CÁLCIO, NA UTILIZAÇÃO INTRACANAL DE PASTAS À BASE DE HIDRÓXIDO DE CÁlCIO, EM FUNÇÃO DO TEMPO E DE DIFERENTES VEÍCULOS. (ESTUDO REALIZADO EM DENTES HUMANOS E BOVINOS)
}

\section{CARLOS HENRIQUE RIBEIRO CAMARGO}

Tese apresentada à Faculdade de Odontologia de Bauru, da Universidade de São Paulo, como parte dos requisitos para obtenção do título de Doutor em Odontologia, área de Endodontia.

(Edição Revisada) 
Camargo, Carlos Henrique Ribeiro

Avaliação do pH e liberação de cálcio, na utilização intracanal de pastas à base de hidróxido de cálcio, em função do tempo e de diferentes veículos, estudo em dentes humanos e bovinos) / Carlos Henrique Ribeiro Camargo. Bauru 2002.

128p. il. ; 30cm.

Tese. (Doutotorado) - Faculdade de Odontologia de Bauru. USP.

Orientador: Norberti Bernardineli 
CARLOS HENRIQUE RIBEIRO CAMARGO

\begin{tabular}{|c|c|}
\hline $\begin{array}{l}18 \text { de janeiro de } 1972 \\
\text { Assis - SP }\end{array}$ & Nascimento \\
\hline 1990-1993 & $\begin{array}{l}\text { Curso de Odontologia - Faculdade de } \\
\text { Odontologia "Júlio de Mesquita Filho" } \\
\text { UNESP - São José dos Campos - SP }\end{array}$ \\
\hline 1995-1998 & $\begin{array}{l}\text { Curso de Pós-Graduação em } \\
\text { Odontologia (Área de Concentração } \\
\text { em Odontologia Restauradora), ao } \\
\text { nível de Mestrado, na Faculdade de } \\
\text { Odontologia "Júlio de Mesquita Filho" } \\
\text { UNESP - São José dos Campos - SP }\end{array}$ \\
\hline 1996 & $\begin{array}{l}\text { Professor Auxiliar de Ensino na } \\
\text { Disciplina de Endodontia da Faculdade } \\
\text { de Odontologia "Júlio de Mesquita } \\
\text { Filho" } \\
\text { UNESP - São José dos Campos - SP }\end{array}$ \\
\hline $2000-2002$ & $\begin{array}{l}\text { Curso de Pós-Graduação em } \\
\text { Endodontia, ao nível de Doutorado, na } \\
\text { Faculdade de Odontologia de Bauru - } \\
\text { Universidade de São Paulo, USP - } \\
\text { Campus de Bauru-SP }\end{array}$ \\
\hline Associações & $\begin{array}{l}\text { APCD - Associação Paulista dos } \\
\text { Cirurgiões Dentistas. } \\
\text { SBPqO - Sociedade Brasileira de } \\
\text { Pesquisas Odontológicas. }\end{array}$ \\
\hline
\end{tabular}




\section{DEDICATÓRIA}

\section{Dedico esse trabalho a Deus!}

Por sua infinita misericórdia e por compreender nossas limitações;

Por nos iluminar nos momentos de maior dificuldade;

Dando-nos acima de tudo a capacidade de termos fé, esperança e amor.

Bem-aventurados os pobres em espírito, pois deles é o Reino dos céus. Bem-aventurados os que choram, pois serão consolados.

Bem-aventurados os humildes, pois eles receberão a Terra por herança. Bem-aventurados os que tem fome e sede de justiça, Pois serão satisfeitos. Bem-aventurados os misericordiosos, Pois obterão misericórdia. Bem-aventurados os puros de coração, Pois verão a Deus.

Bem-aventurados os pacificadores, Pois serão chamados filhos de Deus. Bem-aventurados os perseguidos por causa da justiça, Pois deles é o reino dos céus. 


\section{AGRADECIMENTOS}

Agradeço em primeiro lugar a meus pais:

JOSUÉ E MARIA CAROLINA

Por me ensinarem a amar

Por me darem apoio incondicional nas realizações dos meus anseios.

Por fim por me mostrarem que é possível viver dignamente. 
Ao meu Orientador:

Professor Associado Norberti Bernardineli,

pela orientação e confiança na execução deste trabalho.

Meu Obrigado! 
À grande amiga e colega de Disciplina,

Professora Adjunta Marcia Carneiro Valera,

pela confiança em mim depositada,

pelo incentivo em todos os momentos

e pelo grande exemplo de dedicação ao ensino e a pesquisa.

Minha Eterna Gratidão! 
À Professora Titular Maria Amélia Máximo de Araújo, pelo exemplo de dedicação a Universidade e nunca posso me esquecer de seu empenho para o início de minha carreira Universitária.

Ao Professor Doutor Jaime Freitas Ribeiro, meu orientador de mestrado e incentivador no início de minha carreira.

Ao Professor Alberto Consolaro, pelo exemplo de dedicação à arte de ensinar.

A todos os Professores da Disciplina de Endodontia de Bauru, Professor Titular Clóvis Monteiro Bramante, Professor Doutor Ivaldo Gomes de Moraes, Professor Doutor Roberto Brandão Garcia, Professor Associado Norberti Bernardineli e ao Professor Titular Alceu Bebert; pela calorosa acolhida, pela compreensão e pelos preciosos ensinamentos e exemplo de dedicação à vida acadêmica.

Aos colegas do curso de Doutorado: Carlos Herrero, Christian, Fabiana, Flaviana, Luciana, Patrícia, Sérgio e Vânia. Em especial ao amigo Sérgio T. Maeda que foi o grande companheiro nessa trajetória.

Aos funcionários da Disciplina de Endodontia da FOB, Dona Neide, Edimauro, Suely e Patrícia, pelo carinho e atenção.

Aos meus colegas de Disciplina: Alberto Siqueira e Silva, Ana Paula Martins Gomes e Márcia Carneiro Valera, pela compreensão nos meus períodos de ausência e pelo incentivo na conquista desse objetivo. 
Aos Docentes do Departamento de Odontologia Restauradora da UnespSJCampos: Clóvis Pagani, João Cândido de Carvalho, José Roberto Rodrigues, Maria Filomena R. L. Huhtala, Regina Célia Santos Pinto Silva, Rosehelene Marotta Araújo, Sérgio Eduardo de Paiva Gonçalves; pela amizade e companheirismo. Em especial ao amigo e Chefe de Departamento: Professor Doutor José Roberto Rodrigues pela grande ajuda na correção do trabalho.

Aos funcionários do Departamento de Odontologia Restauradora da Unesp-SJCampos: Dona Lurdes, Liliane, Luis, Michele, Rosângelas e Valdir.

A todos os meus amigos que me incentivaram nesse período em especial ao amigo Emmanuel B. Garakis que me serve de exemplo como cristão.

À amiga e Professora da Disciplina de Bioquímica da Unesp-SJCampos: Maria Nadir pela grande ajuda na execução da parte bioquímica deste trabalho.

À minha namorada, Samira Esteves Afonso pela grande ajuda nessa pesquisa.

Aos Professores Marco Antônio e Ivan Balducci pela realização da análise estatística.

A todos que direta ou indiretamente contribuíram para execução deste trabalho 


\section{SUMÁRIO}

\section{RESUMO}

1. INTRODUÇÃ

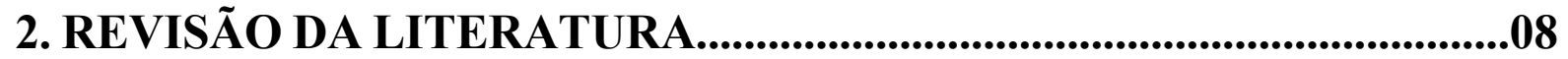

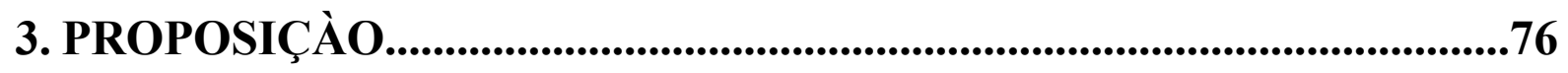

4. MATERIAL E MÉTODOS...................................................................77

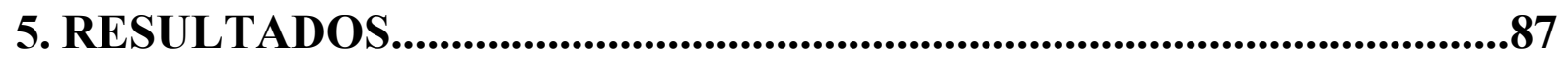

6. DISCUSSÃO

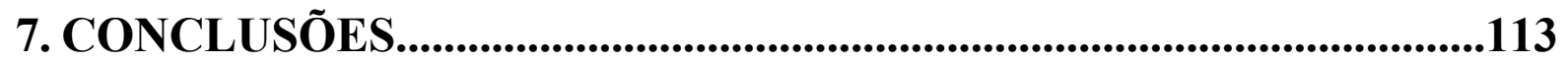

8. REFERÊNCIAS BIBLIOGRÁFICAS..............................................114

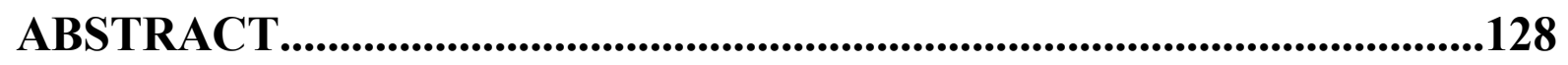




\section{RESUMO}

O propósito deste trabalho foi o de avaliar "in vitro" as alterações do $\mathrm{pH}$ e liberação de íons cálcio, após a utilização intracanal, de pastas de hidróxido de cálcio com diferentes veículos. Nesse estudo foram utilizados 92 dentes, unirradiculados humanos e bovinos, após a remoção das coroas, realizou-se o preparo biomecânico $1 \mathrm{~mm}$ aquém do forame com irrigação de hipoclorito de sódio 2,5\%, seguido de irrigação final com EDTA. No terço médio de cada espécime, na face vestibular, foi realizado um preparo com $4 \mathrm{~mm}$ de comprimento $\mathrm{X} 2 \mathrm{~mm}$ de largura e $1 \mathrm{~mm}$ de profundidade. As raízes foram divididas em dois grupos: 46 humanas e 46 bovinas. Cada grupo foi subdividido em 4 subgrupos de acordo com o veículo a ser utilizado, subgrupo 1: detergente; subgrupo 2: solução salina; subgrupo 3 : polietilenoglicol $400 \quad+$ paramonoclorofenol canforado (Calen PMCC) e subgrupo 4: polietilenoglicol $400+$ paramonoclorofenol furacinado (PMCF). A raízes foram impermeabilizadas externamente, exceto na área da cavidade. Cada espécime foi imerso individualmente em frascos contendo $4 \mathrm{ml}$ de solução salina fisiológica e, mantidos à $37^{\circ} \mathrm{C}$. As mensurações de $\mathrm{pH}$ e liberação de cálcio foram feitas aos 7 e 14 dias. As raízes humanas e bovinas permitiram um comportamento semelhante para a análise de $\mathrm{pH}$ e da liberação de cálcio. O Calen PMCC foi estatisticamente superior em todas as análises, seguido pelo PMCF e solução salina, que se equivaleram e por último o detergente foi estatisticamente inferior aos demais grupos. O período de 14 dias se mostrou mais adequado, mostrando aumento na liberação iônica. 


\section{INTRODUÇÃO}

Com a evolução dos recursos aplicados à terapia endodôntica e a necessidade de racionalização do tratamento, devido à premissa de tempo, condicionada aos dias atuais; observamos o surgimento de novas técnicas de instrumentação automatizada, obturações utilizando guta-percha termoplastificada, além do grande número de pesquisas avaliando a ação de lasers na limpeza e redução do número de microrganismos no sistema de canais radiculares; facilitando as manobras técnicas. Porém, mesmo com todo o progresso científico e tecnológico alcançado pela Endodontia, nos dias atuais, com o intuito de eliminar etapas agilizando o tratamento, na presença de infecção no sistema de canais radiculares, a fase de desinfecção desse sistema é imprescindível para a eliminação de microrganismos nas áreas em que a terapia convencional não tem acesso (canais laterais e secundários, delta apical, massa dentinária e crateras de reabsorção).

Para a fase de desinfecção, dentre os diferentes medicamentos propostos, $o$ hidróxido de cálcio, com outros materiais adicionados a ele ou não, é o medicamento mais utilizado atualmente. O hidróxido de cálcio é um pó branco inodoro de peso molecular 74,08, que apresenta baixa solubilidade em água $\left(1,2 \mathrm{~g} / 1\right.$ a $\left.25^{\circ} \mathrm{C}\right)$, o que é favorável clinicamente, permitindo uma ação mais prolongada. Quimicamente é classificado como uma base forte. Sua ação está 
relacionada à liberação dos íons cálcio e hidroxila, sendo que a associação do hidróxido de cálcio a um veículo apropriado origina uma pasta alcalina. Esse material foi introduzido na Endodontia em 1920 por HERMANN (citado por FAVA; SAUNDERS ${ }^{25}$, 1999), que desenvolveu a pasta Calxyl à base deste produto que tem sido considerado, há muito tempo, como medicamento de escolha para o tratamento de canais radiculares com mortificação pulpar, devido as suas excelentes propriedades antimicrobianas, com elevado $\mathrm{pH}$ (BARBOSA et $a l^{3}, 1997$; BARBOSA et $a l^{4}, 1994$; BAUMGARTNER; FALKER ${ }^{6}, 1991$; ESTRELA et $a l^{20}, 2001$; ESTRELA et $a l^{21}, 1999 ;$ ESTRELA et $a l^{22}, 1999$; ESTRELA et $a l^{23}, 1998 ;$ HAN et $a l^{38}, 2001$; LEONARDO et $a l^{54}, 2000$; SIQUEIRA; LOPES ${ }^{77}$, 1999; SIQUEIRA et $a l^{78}, 1998$; SJÖGREN et $a l^{79}$, 1991; STUART et $a l^{80}$, 1991; SUNDQVIST et $a l^{81}$, 1989), ação contra lipopolissacarídeos (BUCK et $a l^{8}$, 2001; SAFAVI; NICHOLS ${ }^{68}, 1994$; SAFAVI; NICHOLS ${ }^{69}, 1993$ ), absorção de $\mathrm{CO}_{2}$ (KONTAKIOTIS et at ${ }^{49}, 1995$; FUSS et $a l^{28}, 1996$; MIÑANA et $a l^{58}, 2001$ ), além da ação antinflamatória e indutora de reparação (DSTOMAT et $a l^{17}$, 2000; FAVA et $a l^{24}$, 2000; FAVA et $a l^{25}, 1999 ;$ FOREMAN; BARNES ${ }^{26}, 1990 ;$ HAMMARSTRÖM et $a l^{39}, 1986$; HOLLAND et $a t^{43}, 1998 ;$ HOLLAND et $a t^{44}, 1999$; HOLLAND et $a t^{45} 2001$; NELSON FILHO et $a l^{60}, 1999$; TROPE et $\left.a l^{87}, 1999\right)$.

As indicações do hidróxido de cálcio dentro da Odontologia Restauradora e Endodontia são inúmeras: forramento de cavidades profundas; capeamento 
indireto e direto da polpa; pulpotomia; medicação intracanal em biopulpectomias e necropulpectomias; apicificação; neutralização da agressão de agentes clareadores (FUSS et $\left.a l^{29}, 1989 ; \mathrm{KEHOE}^{48}, 1987\right)$; prevenção e controle de reabsorções radiculares externas e internas (TRONSTAD et al ${ }^{86}$, 1981); reparo de perfurações (TROPE et $a l^{87}$, 1999); tratamento dos traumatismos dentários como fraturas, luxações, intrusões e avulsões (TRONSTAD et $a l^{86}, 1981$ ); contenção de hemorragia (FAVA et $a l^{24}, 2000$ ); controle de exsudações persistentes (McCORMICK et al $t^{57}$, 1983); dissolução de matéria orgânica (GORDON; ALEXANDER ${ }^{33}$, 1985; HASSELGREN et a ${ }^{40}$, 1988; MARION et $a l^{56}, 1991$; WAKABAYASHI et $\left.a l^{91}, 1995\right)$; prevenção de contaminação coronária durante o tratamento endodôntico (SIQUEIRA et $a l^{78}$, 1998); além ser incorporado a cimentos endodônticos (ÇALT; SERPER ${ }^{11}, 1999$; ESBERARD et al ${ }^{19}$, 1996; GORDON; ALEXANDER ${ }^{32}$, 1986; TAGGER et $a l^{82}, 1988$ ); cimentos para forramento de cavidades (LEONARDO et al $l^{55}, 1992$ ) e cones de guta-percha (SCHÄFER; BEHAISSI ${ }^{70}$, 2000). Porém, não apresenta a mesma capacidade de dissociação iônica nestas duas últimas indicações (ÇALT; SERPER ${ }^{11}, \quad 1999 ; \quad$ ESBERARD et $a l^{19}$, 1996; GORDON; ALEXANDER $^{32}$, 1986; SCHÄFER; BEHAISSI ${ }^{70}, 2000$; TAGGER et al ${ }^{82}$, 1988).

Para ser usado como pasta necessita de um veículo, podendo ainda ser associado a outras substâncias para melhorar suas propriedades físico-químicas 
como: radiopacidade, escoamento e consistência. O veículo determina a velocidade de dissociação do hidróxido de cálcio em íons cálcio e hidroxila, determinando a capacidade de solubilização e reabsorção da pasta nos tecidos apicais, velocidade de liberação dos íons e não possuir efeito adverso na indução de deposição de tecido duro (FAVA; SAUNDERS ${ }^{25}$, 1999). Em geral são utilizados três tipos de veículos: aquosos, viscosos e oleosos. Os veículos aquosos são solúveis em água, promovem dissociação rápida dos íons cálcio e hidroxila, possuem alto grau de solubilidade em contato com os tecidos apicais e fluidos teciduais, sendo reabsorvidos por macrófagos (FAVA; SAUNDERS ${ }^{25}$, 1999). Têm menor tempo de ação, necessitando de trocas mais freqüentes. Como exemplos temos a água, solução salina, solução de ringer, suspensão aquosa de metilcelulose ou carboximetilcelulose e solução de detergente aniônico, solução anestésica e outros. Estes veículos são mais indicados quando há necessidade de modificações rápidas do $\mathrm{pH}$, nos casos de traumatismos dentários, urgências em endodontia, e outros (FAVA; SAUNDERS ${ }^{25}$, 1999). Os veículos viscosos são solúveis em água, liberam mais lentamente os íons cálcio e hidroxila, possuindo uma atividade mais duradoura necessitando menor número de trocas, isso provavelmente devido ao maior peso molecular desses veículos, que minimiza a dispersão do hidróxido de cálcio, atuando de 2 a 4 meses (FAVA; SAUNDERS ${ }^{25}$, 1999). Como exemplos podemos citar a glicerina, propilenoglicol, polietilenoglicol e outros. Estes veículos estão 
indicados quando há necessidade de uma liberação lenta dos íons, e possibilitando um menor número de trocas, como nos casos de lesões extensas, apicificação, e outros. Os veículos oleosos não são solúveis em água, promovendo baixa solubilidade e difusão nos tecidos, tendo seu uso clínico comprometido. Como exemplos tem-se o óleo de oliva, óleo de silicone, cânfora, metacresilacetato e alguns ácidos gordurosos, tipo ácido oléico, linoléico e isosteárico e outros (FAVA; SAUNDERS ${ }^{25}$, 1999).

A alteração do pH da dentina, pela difusão dos íons hidroxila pelos túbulos dentinários, tem sido motivo de muitos estudos, que tentam verificar a passagem dos íons cálcio e hidroxila pelos túbulos dentinários, alcalinizando a massa dentinária. Verificando também as reações entre a dentina e as pastas de hidróxido de cálcio, como a possível inativação do $\mathrm{pH}$ do hidróxido de cálcio pelos fluidos dentinários, influenciando a tensão superficial das pastas de hidróxido de cálcio, a sua capacidade de dissolução e outras propriedades (ALAÇAM et $a l^{1}, 1998 ;$ ANTHONY et $a l^{2}, 1982$; BELTES et al ${ }^{7}, 1997$; ÇALT et $a l^{12}$, 1999; CÁRDENAS et $a l^{13}, 2001$; DEADORF et $a l^{15}$, 1994; ESBERARD et $a l^{18}, 1996$; FOSTER et $a l^{27}, 1993$; FUSS et $a l^{28}, 1996$; FUSS et al ${ }^{29}, 1989$; GOMES et $a l^{31}$, 1996; GUIGAND et $a l^{35}, 1997$; GUIGNES et $a l^{36}, 1996$; HAAPASALO et $a l^{37}, 2000 ;$ HOSOYA et $a l^{46}, 2001 ; \mathrm{KEHOE}^{48}, 1987$; LARSEN; BINDSLEV ${ }^{52}$, 2000; LEONARDO et a l $^{53}$, 1993; LEONARDO et $a l^{55}, 1992$; MINAMA $e t a l^{58}, 2001$; MURRAY et $a l^{59}, 2000$; NERWICH et $a l^{61}$, 
1993; ÖZCELIK et $a l^{63}$, 2000; PASHLEY et al ${ }^{64}$, 1978; SAFAVI; NAKAYAMA $^{67}, 2000 ;$ SIMON et $a l^{74}, 1995$; TRONSTAD et al ${ }^{86}, 1981$; VONGSAVAN et al ${ }^{88}$, 2000; WANG; HUME $\left.{ }^{90}, 1988\right)$.

A difusão do hidróxido de cálcio também é influenciada pelo diâmetro dos túbulos dentinários, que podem estar diminuídos no indivíduo senil, ou por um processo de envelhecimento precoce da polpa (CARRIGAN et al ${ }^{14}, 1984$; GARBEROGLIO; BRANNSTRON ${ }^{30}, 1976$; TIDMARSH; ARROWSMITH ${ }^{84}$, 1989) como também pelo tipo de tratamento das paredes dentinárias e a presença de smear layer.

A necessidade e a eficiência do uso de agentes quelantes tem sido questionada e, diversos materiais e técnicas têm surgido como alternativas para a remoção da smear layer. Porém sua remoção é considerada imprescindível para uma boa desinfecção dos canais radiculares (YOSHIDA et a $\ell^{93}$, 1995; FOSTER et $\left.a l^{27}, 1993\right)$ e, para melhorar a difusão dos medicamentos pelos túbulos dentinários (BARKHORDAR et al, 1997 ; FOSTER et al ${ }^{27}, 1993$; KOULAOUZIDOU et $a l^{50}, 1999$; O'CONNEL et $a l^{62}, 2000$; SEN et $a l^{72}, 1995$; TAKEDA et $a l^{83}, 1999$; TIMPAWAT et $\left.a l^{85}, 2001\right)$.

O tempo de permanência dos curativos à base de hidróxido de cálcio no interior dos canais, também é motivo para estudo, pois alguns autores acreditam que são necessários no mínimo 14 dias para que os íons cálcio e hidroxila tenham uma penetração na massa dentinária e cheguem próximo à superfície 
radicular (CÁRDENAS et $a l^{13}, 2001$; ESBERARD et $a l^{18}$, 1996; GOMES et $a l^{31}, 1996$; HOSOYA et $a l^{46}, 2001$; NERWICH et $a l^{61}, 1993$; SIMON et $a l^{74}$, 1995; TRONSTAD et $\left.a l^{86}, 1981\right)$. Outros autores acreditam que cinco a sete dias já são suficientes para que o medicamento exerça sua função (BELTES et $a l^{7}$, 1997; TROPE et al $\left.{ }^{87}, 1999\right)$.

A verificação do efeito de diferentes veículos na difusão do hidróxido de cálcio, pela massa dentinária e sistema de canais radiculares e o estabelecimento de protocolos para o tempo de permanência do medicamento no interior do canal radicular, são de extrema importância para o uso clínico desses materiais. Isto levou-nos a avaliar a difusão de pastas de hidróxido de cálcio, com diferentes veículos, por meio das alterações no pH radicular externo e liberação de cálcio, em dentes humanos e bovinos. Para justificar esta proposta, realizou-se uma revisão da literatura relacionada ao assunto. 


\section{REVISÃO DA LITERATURA}

Para melhor compreensão do assunto a revisão da literatura foi dividida em tópicos:

\subsection{Anatomia dos túbulos dentinários.}

O conhecimento da anatomia radicular é de extrema necessidade para compreensão do mecanismo de permeabilidade dentinária e conseqüente ação do hidróxido de cálcio.

GARBEROGLIO; BRANNSTROM ${ }^{30}$ (1976) verificaram por microscopia eletrônica de varredura que dentes humanos, apresentavam próximo à polpa, 45.000 túbulos dentinários $/ \mathrm{mm}^{2}$ com diâmetro de 2,5 $\mu \mathrm{m}$; na metade da distância

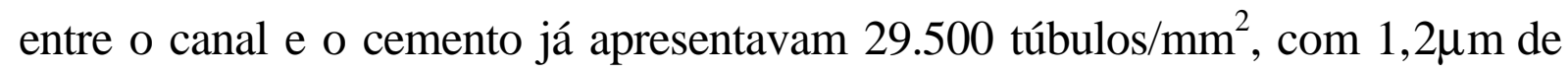
diâmetro e na periferia da dentina o número de túbulos foi de 20.000 túbulos $/ \mathrm{mm}^{2}$, e $0,9 \mu \mathrm{m}$ de diâmetro, mostrando a diminuição do número e do calibre dos túbulos na luz do canal até as proximidades do cemento. 
Em 1984 CARRIGAN et $a l^{14}$ realizaram uma avaliação dos túbulos dentinários humanos em microscopia eletrônica de varredura, de acordo com a idade dos pacientes e localização dos túbulos. Os dados observados nesse trabalho mostram que nos indivíduos de 20 a 34 anos a média do número de túbulos nos três terços foi de 242.775 túbulos $/ \mathrm{mm}^{2}$, dos 35 aos 44 foi de 230.300 túbulos $/ \mathrm{mm}^{2}$, dos 45 aos 54 foi de 195.750 túbulos $/ \mathrm{mm}^{2}$, dos 55 aos 79 foi de 185,900 túbulos $/ \mathrm{mm}^{2}$ e acima dos 80 anos foi de 149.025 túbulos $/ \mathrm{mm}^{2}$. Evidenciando uma redução no número médio de túbulos por milímetro quadrado com o passar do tempo. De acordo com as áreas da dentina, os resultados foram: terço apical 49.140 túbulos $/ \mathrm{mm}^{2}$, terço médio 234,060 túbulos $/ \mathrm{mm}^{2}$ e terço cervical 254.340 túbulos $/ \mathrm{mm}^{2}$. Neste trabalho, pôde-se verificar que com o aumento da idade, e na direção cervical-apical, o número e o calibre dos túbulos dentinários diminuem.

TIDMARSH; ARROWSMITH ${ }^{84}$ (1989), observaram as características dos túbulos dentinários da região apical de dentes humanos, por microscopia eletrônica de varredura. Os dentes foram divididos em 2 grupos:

$\checkmark$ Grupo 1 - dentes de indivíduos com idade desconhecida

$\checkmark$ Grupo 2 - dentes de indivíduos com idade conhecida

Os ápices foram removidos a distância de 2 e $4 \mathrm{~mm}$ em ângulos de 45 e $60^{\circ}$ e as raízes seccionadas longitudinalmente. A análise em microscopia de varredura mostrou que: no grupo 1 o número e a orientação dos túbulos variou de acordo 
com o nível e o ângulo de secção; no grupo 2 na proximidade do canal radicular o número de túbulos foi em média 28000 túbulos $/ \mathrm{mm}^{2}$; a 1⁄2 distância entre o canal e a superfície radicular foi de 18000 túbulos $/ \mathrm{mm}^{2}$ e na junção dentinacemento 13000 túbulos $/ \mathrm{mm}^{2}$. Evidenciando uma diminuição no calibre dos túbulos, da luz do canal em direção ao cemento. Com o aumento da idade também foi possível verificar a diminuição do número e do calibre dos túbulos.

\subsection{Permeabilidade dentinária e difusão de íons cálcio e hidroxila.}

Diversos trabalhos inter-relacionam as reações entre os materiais, tratamento da dentina e seus efeitos sobre a permeabilidade dentinária.

Em 1978, PASHEY et at ${ }^{64}$ pesquisaram a influência do grau de oclusão dos túbulos dentinários na permeabilidade da dentina humana in vitro, utilizando ${ }^{131} \mathrm{I}$ - Albumin e $3 \mathrm{H}_{2} \mathrm{O}$, após formação de smear layer, com uso de brocas, lixa, oxalato; e após a remoção da smear layer com ataque ácido. O que se pode observar foi uma diminuição significativa da permeabilidade quando da obliteração dos túbulos dentinários.

TRONSTAD et $a l^{86}$ (1981), em um trabalho clássico da literatura, verificaram as alterações de $\mathrm{pH}$ nos tecidos dentários de macacos, que tiveram seus canais radiculares preenchidos com hidróxido de cálcio. Doze dentes foram preparados e suas coroas foram seladas, outros 15 dentes foram extraídos, 
mantidos secos sobre a bancada por $1 \mathrm{~h}$ e reimplantados sem colocação de contenção. Após 4 semanas ambos os dentes receberam preparos biomecânicos e os canais foram preenchidos com hidróxido de cálcio associado à solução de Ringer. Depois de quatro semanas os animais foram sacrificados e as maxilas e mandíbulas congeladas. Os espécimes foram embebidos em metilcelulose e cortados em micrótomo; 27 dentes foram cortados perpendicularmente ao longo eixo do dente e 5 dentes paralelamente. Indicadores de $\mathrm{pH}$ foram colocados sobre a superfície do dente cortado e a alteração de cor das fitas indicadoras registrava a mudança do $\mathrm{pH}$. $\mathrm{O} \mathrm{pH}$ foi medido em quatro áreas da raiz, seccionadas no sentido transversal, denominadas $1,2,3$ e 4 do cemento em direção ao canal. $\mathrm{Na}$ área do canal o pH estava entre 10 e 12,2; nas áreas 3 e 4 o pH estava entre 8 e 11,1; nas áreas 1 e 2 o pH estava entre 7,4 e 9,6. Não houve diferença entre os dentes reimplantados e não reimplantados, e também não houve diferença entre os dentes com ápice completo e incompleto.

ANTHONY et $a l^{2}$ (1982), prepararam os canais de dentes unirradiculados e realizaram cavidades externas em cada dente, após isso foram colocadas pastas de hidróxido de cálcio no interior dos canais e as porções apical e cervical impermeabilizadas. Os dentes foram colocados em $10 \mathrm{ml}$ de água destilada e o $\mathrm{pH}$ verificado em diferentes períodos, comparando três veículos para o hidróxido de cálcio em pó: a cresatina que teve um comportamento ruim pela reação do hidróxido de cálcio e o metacrilacetado, formando ácido acético, 
reduzindo o $\mathrm{pH}$; o paramonoclorofenol canforado produziu altos valores de $\mathrm{pH}$. Esse aumento foi provavelmente devido ao paramonoclorofenol que quando adicionado ao hidróxido de cálcio, pode produzir um sal fraco chamado pclorofenolato de cálcio, que em solução aquosa liga-se aos íons hidrogênio que retornam ao paramonoclorofenol, provocando excesso de íons hidroxila aumentando o $\mathrm{pH}$ e; por último a solução salina que foi pouco inferior ao PMCC. Nenhum dos grupos produziu um $\mathrm{pH}$ maior que 9,6. Os autores salientam que um ambiente ácido gera um acúmulo de AMP cíclico no citoplasma do osteoclasto, que afeta a mitocôndria, aumentando a concentração de íons cálcio dentro da célula. Esse aumento estimula a liberação de enzimas lisossomais que se difundem para o fluido ósseo gerando um aumento de natureza ácida nesse fluido, devido a um acúmulo de ácido lático e a adição de hidrolases ácidas. Além do que um ambiente alcalino pode favorecer a formação de complexos, cálcio-fósforo, ao invés de quebrá-los e, esses complexos podem servir de nichos para futuras calcificações.

McCORMICK et $a l^{57}$ (1983), avaliaram qual o $\mathrm{pH}$ tecidual durante o desenvolvimento de lesões periapicais em cachorros. Os autores ressaltam que na inflamação aguda o pH é ligeiramente ácido, resultado da glicólise anaeróbica com formação de ácido lático e queda do $\mathrm{pH}$, a estase sanguínea contribui para o aumento na concentração de $\mathrm{CO}_{2}$, aumentando a acidose tecidual, favorecida pela chegada dos PMN Neutrófilos, que atuam nesse 
ambiente liberando enzimas lisossomais proteolíticas, promovendo necrose por liquefação com formação de conteúdo purulento. $\mathrm{Na}$ inflamação crônica o pH quase não se altera, devido ao aumento da vascularização local. Foram utilizados nesse trabalho 6 beagles de 5 meses de idade. Os dentes foram abertos e depois de feito a odontometria o $\mathrm{pH}$ foi medido no interior dos canais com um microeletrodo colocado imediatamente abaixo do comprimento de trabalho, estabelecido $1 \mathrm{~mm}$ aquém do ápice radiográfico. Soluções de Streptococcus faecalis foram injetadas no interior dos canais e os dentes selados com lâminas de guta-percha e amálgama. Após uma semana os dentes foram reabertos e o pH novamente medido, os canais foram preparados, secos com cones de papel e duas pastas colocadas no interior dos mesmos. Metade dos canais receberam pasta ácida à base de: metilcelulose, água estéril e ácido hidroclorídrico ( $\mathrm{pH} 3)$, a outra metade recebeu uma pasta básica à base de: metilcelulose, água estéril e hidróxido de sódio ( $\mathrm{pH}$ 11). Os resultados iniciais foram $\mathrm{pH}$ de 7,1 a 7,2 (tecido normal), após a injeção de microrganismos (inflamação aguda pH 6,4), e após a aplicação das pastas não houve diferença (inflamação crônica) o pH ficou em torno de 7,0 .

$\mathrm{KEHOE}^{48}$ em (1987), verificou a reversão do $\mathrm{pH}$ em dentes tratados endodonticamente após clareamento in vitro. Vinte incisivos foram tratados endodonticamente e clareados pela técnica mediata (peróxido de hidrogênio $30 \%$ + perborato de sódio). $\mathrm{O} \mathrm{pH}$ foi mensurado antes, durante e após o 
clareamento $1,5 \mathrm{~mm}$ abaixo da junção amelo cementária. Os dentes foram divididos em 2 grupos, em cada grupo 5 dentes tiveram seu cemento removido. No grupo 1 foi utilizado um microeletrodo para verificar o $\mathrm{pH}$, no grupo 2 foi utilizado papel indicador. Vinte e quatro horas após a aplicação da pasta clareadora o $\mathrm{pH}$ foi de aproximadamente $6,52 \mathrm{e}, 48 \mathrm{~h}$ depois 6,73 para o grupo 1 (com cemento) e 6,49 (sem cemento) e, no grupo 2: 6,7 (com cemento) e 6,6 (sem cemento). No sexto dia após o clareamento foi colocado hidróxido de cálcio em veículo aquoso e o $\mathrm{pH}$ foi aumentando gradualmente; no décimo quinto dia o pH estava: 7,30 para o grupo 1 (com cemento) e 8,11 (sem cemento) e, no grupo 2: 7,5 (com cemento) e 8,1 (sem cemento). Houve uma acidificação da dentina e do cemento após o clareamento que foi revertida com o uso do hidróxido de cálcio.

WANG; HUME $^{90}$ (1988), pesquisaram a difusão de íons hidrogênio e hidroxila, de várias origens, através da dentina. Foram utilizados terceiros molares humanos de indivíduos de 18 a 24 anos. Cada dente foi incorporado a uma câmara dual (uma parte coronária e uma parte apical; preparo cavitário e câmara pulpar respectivamente), com um preparo coronário separando as duas câmaras, com aproximadamente $2 \mathrm{~mm}$ espessura de dentina. A coroa foi selada com cera pegajosa para separar as duas câmaras. Um pHmetro foi adaptado a câmara pulpar, que continha solução salina, e os materiais colocados na cavidade coronária foram: 
$\checkmark$ Cimento de Oxido de Zinco e Eugenol;

$\checkmark$ Cimento de Fosfato de Zinco;

$\checkmark$ Pó de Hidróxido de Cálcio;

$\checkmark$ Dycal 0,8mm de espessura;

$\checkmark$ Dycal 2mm de espessura.

O efeito tampão da dentina não permitiu a passagem mais profunda de íons hidrogênio dos compostos ácidos testados, porém ácidos fracos podem se difundir pela dentina sem se dissociar escapando do efeito tampão. A capacidade tampão da dentina para substâncias alcalinas parece ser mais limitada.

FUSS et $a l^{29}$ (1989), avaliaram a permeabilidade dos túbulos dentinários ao hidróxido de cálcio e um agente clareador. Trinta dentes foram divididos em 3 grupos:

$\checkmark$ Grupo 1 - Amosan (peróxido de hidrogênio a 30\%) pH 9,2

$\checkmark$ Grupo 2 - Hidróxido de cálcio + água destilada pH 12,8

$\checkmark$ Grupo 3 - Bolinha de algodão seca

Os dentes foram selados com parafina com exceção da área cervical, e colocados em frascos individuais contendo $40 \mathrm{ml}$ de água destilada. $\mathrm{O} \mathrm{pH}$ foi mensurado após 1h, 3 e 7 dias com renovação do meio. $\mathrm{O}$ pH do grupo 1 aumentou indicando que o agente clareador infiltrou até a área cervical, podendo este agente iniciar uma inflamação no periodonto lateral, dando origem a uma 
reabsorção cervical externa. No entanto, o pH dos outros dois grupos não se alterou, mostrando que o hidróxido de cálcio não foi capaz de alcalinizar o meio. FOREMAN; BARNES ${ }^{26}$ (1990), realizaram uma revisão de literatura sobre o hidróxido de cálcio, considerando supostas atuações: Ação bioquímica na indução da mineralização, atuando sobre o colágeno, entre a dentina e o osso. Este processo provavelmente resulta da justaposição de grupos carregados sobre macromoléculas adjacentes, as quais aumentam os centros epitáticos, que requerem um sítio nucleado, podendo processar a formação de hidroxiapatita e ativando enzimas do grupo da fosfatase alcalina, como: Pirofosfatase cálcio dependente, Adenosina cálcio ATPase e outras. Devido ao seu elevado pH próximo ao 12 , o hidróxido de cálcio também pode neutralizar o ácido lático secretado pelos osteoclastos, diminuindo assim a reabsorção óssea. Também é proposta sua ação antinflamatória pela capacidade de sorpção dos exsudatos e formação de ponte de proteinato de cálcio, diminuindo a saída de líquidos dos vasos sangüíneos para o interstício.

LEONARDO et $a t^{55}$ (1992), mediram as variações de pH e liberação de íons cálcio em produtos à base de hidróxido de cálcio, em diferentes intervalos de tempo. Os produtos testados foram:

$\checkmark$ hidróxido de cálcio + água destilada (Caal);

$\checkmark$ hidróxido de cálcio + polietilenoglicol (Calen);

$\checkmark$ hidróxido de cálcio + polietilenoglicol + PMCC (Calen PMCC); 
$\checkmark$ hidróxido de cálcio + água estéril (Calasept);

$\checkmark$ e os cimentos obturadores CRCS e Sealapex.

As pastas foram espatuladas com 1,5g do material para $6 \mathrm{ml}$ de água destilada, armazenadas em frascos vedados e mantidas a $36,5^{\circ} \mathrm{C} . \mathrm{O} \mathrm{pH}$ foi medido em 1,3 , 24, 48, 72h, 30 e 60 dias, com 5 amostras para cada material, em cada intervalo de tempo. Para a análise de liberação de íons cálcio as pastas foram preparadas da mesma maneira que para a análise de $\mathrm{pH}$ e, as soluções foram pipetadas e analisadas por espectrofotometria nos intervalos de 5min, 72h, 7, 30 e 60 dias. Três amostras foram utilizadas para cada material, em cada intervalo de tempo. O hidróxido de cálcio p.a e o Calasept, tiveram valores estáveis do início ao fim do experimento, o Calen e o Calen PMCC tiveram discreto aumento de $\mathrm{pH}$ até ás primeiras $24 \mathrm{~h}$, se estabilizando a partir desse período. Quanto à liberação de íons cálcio, no início a solução aquosa de hidróxido de cálcio liberou maior número de íons e no final do período o Calen proporcionou a maior liberação.

LEONARDO et $a l^{53}$ (1993), observaram a penetrabilidade de curativos intra-canais na massa dentinária de dentes unirradiculados humanos. Cinqüenta incisivos centrais superiores foram instrumentados e a smear layer removida com EDTA, aplicado por 3 a 4 min. Os dentes foram divididos em 5 grupos:

$\checkmark$ Grupo 1 - paramonoclorofenol canforado 2,5:7,5;

$\checkmark$ Grupo 2 - Calen (SSWhite - Brasil);

$\checkmark$ Grupo 3 - Calen PMCC (SSWhite - Brasil); 
$\checkmark$ Grupo 4 - Calen + PMC;

$\checkmark$ Grupo 5 - Hidróxido de Cálcio em veículo aquoso.

Para avaliação da penetração dos curativos, eles receberam adição de um corante de cor violeta $[\mathrm{Zn}(\mathrm{Ne}) 2]$ tamponado em $\mathrm{pH} 10$; permanecendo 7 dias em $100 \%$ de umidade à $37^{\circ} \mathrm{C}$. Os espécimes foram seccionados no sentido longitudinal e as infiltrações do corante foram medidas em milímetros, do canal em direção à superfície radicular. As médias de infiltração foram: Grupo 1 - 0,148; Grupo 2 0,447; Grupo 3 - 0,711; Grupo 4 - 0,797; Grupo 5 - 1,038. Os resultados mostraram melhores resultados para os grupos 3, 4 e 5 sem diferença estatística entre eles e os piores resultados foram observados para o grupo 1 onde o PMCC foi aplicado nos canais com cones de papel absorvente.

NERWICH et at ${ }^{61}$ (1993), pesquisaram as alterações no pH da dentina radicular, no período de 4 semanas, após colocação de curativo de hidróxido de cálcio no interior de vinte canais radiculares. Foram feitas quatro cavidades de 1,75mm de diâmetro em cada dente: duas na porção cervical, 3 a $5 \mathrm{~mm}$ da junção amelo-cementária; uma a $1 \mathrm{~mm}$ da dentina (cervical interna), outra a $0,5 \mathrm{~mm}$ da superfície radicular (cervical externa); outras duas na porção apical 3 a $5 \mathrm{~mm}$ do ápice, uma a $1 \mathrm{~mm}$ da dentina (apical interna), outra a $0,5 \mathrm{~mm}$ da superfície radicular (apical externa). Os canais foram preparados e a smear layer removida pela aplicação de EDTA $17 \%$ no interior dos canais e nas cavidades por 3 a 4min. Dez dentes receberam injeção de hidróxido de cálcio (Calasept: Scania 
Dental, Sweden) e os $4 \mathrm{~mm}$ coronários foram selados com cimento temporário. Cada dente foi colocado em $100 \mathrm{ml}$ de solução salina isotônica à $37^{0} \mathrm{C} . \mathrm{O}$ pH foi medido nos períodos de $0,3,6,12,24,48 \mathrm{~h}$ e 7, 21 e 28 dias. A mensuração do $\mathrm{pH}$ foi feita com microeletrodo, colocado direto na cavidade confeccionada na superfície radicular. Os valores médios $\mathrm{pH}$ foram: Grupo controle, $\mathrm{pH} \mathrm{8,02}$ apical externa; 8,02 apical interna; 8,01 cervical externa; 7,83 cervical interna e 7,9 na superfície radicular. No grupo experimental os valores de $\mathrm{pH}$ 8,85 apical externa; 9,39 apical interna; 8,69 cervical externa; 10,32 cervical interna e 8,1 na superfície radicular. A velocidade de difusão dos íons na região cervical, foi bem maior que na região apical. Devido a maior permeabilidade dessa região, graças ao maior número de túbulos dentinários e maior calibre desses túbulos. Também há uma diminuição do calibre dos túbulos nas proximidades do cemento, a direção dos túbulos diverge e a concentração do soluto se dissipa com a distância, chegando poucos íons na superfície radicular. A permeabilidade dentinária ocorre especificamente por transporte de difusão (pela anatomia tubular, em sua densidade, diâmetro e comprimento) e também pelas características do soluto (tamanho da carga). Os íons hidroxila também podem ser afetados pelo efeito tampão da dentina, adsorção e carga da dentina.

DEARDORF et $a l^{15}$ (1994), pesquisaram os efeitos do tratamento endodôntico na permeabilidade dentinária. Sessenta e três dentes tiveram seus canais radiculares preparados e a superfície externa do cemento foi removida. 
Um sulco circunferencial foi realizado na superfície externa da raiz a $3 \mathrm{~mm}$ do ápice. Para limpeza final foi utilizado ácido cítrico $50 \%$ por $3 \mathrm{~min}$, neutralizado com água deionizada por 1 min. Foram realizados 4 testes: No teste 1 cada espécime foi colocado em um tubo com $2 \mathrm{ml}$ de água deionizada, fechados com parafina,incubados sob agitação a $37^{0} \mathrm{C}$, por 7 dias. Todo resíduo extra-radicular foi decantado em um tubo e renovou-se a água deionizada. A solução decantada, foi analisada por espectrofotometria de absorção atômica para cálcio. No teste 2 , os espécimes do teste 1 foram reabertos no orifício cervical, os canais secos com cones de papel, injetou-se hidróxido de cálcio no interior dos canais (TempCanal - Pulpodent) e foi realizado o mesmo teste descrito acima. No teste 3 os mesmos espécimes foram reabertos e os resíduos da pasta de hidróxido de cálcio removidos com 10ml de água destilada. Os espécimes foram colocados em banho de ultra-som, por 2 períodos de 7 minutos, e lavados em água corrente por 3 dias. Irrigados com 10ml de água deionizada no interior dos canais e estocados em água deionizada por 7 dias. Após isso os canais foram reabertos, secos com cones de papel e novamente selados e estocados da mesma maneira. Após 7 dias foi realizada outra espectrofotometria do resíduo decantado. No teste 4 os 63 espécimes foram divididos em 3 grupos:

- Grupo A - uso de ultra-som com hipoclorito de sódio 5,25\%;

- Grupo B - aplicação de EDTA $17 \%$ por 3min, e hipoclorito de sódio $5,25 \%$ 
- Grupo C - Controle hipoclorito de sódio a 2,5\% por $3 \mathrm{~min}$.

Cada espécime foi estocado individualmente como nos outros testes. E após sete dias os canais foram reabertos, secos e novamente injetado pasta de hidróxido de cálcio (TempCanal). Os canais selados e estocados do mesmo modo. Os resultados estão expressos no quadro abaixo e não apresentaram diferença estatisticamente significante.

Quadro 1 - Representa a quantidade de cálcio $\mu \mathrm{g} / \mathrm{ml}$ liberada durante o experimento:

\begin{tabular}{|c|c|c|c|c|}
\hline Grupos & Teste 1 & Teste 2 & Teste 3 & Teste 4 \\
\hline A & 42 & 305 & 139 & 259 \\
\hline B & 39 & 284 & 160 & 220 \\
\hline C & 36 & 222 & 134 & 270 \\
\hline
\end{tabular}

SIMON et $a l^{74}$ (1995), pesquisaram o efeito de quatro veículos sobre o $\mathrm{pH}$ e a liberação de íons cálcio, em pastas à base de hidróxido de cálcio. Foram utilizados neste estudo 40 premolares inferiores, preparados até o diâmetro 0,70mm, e foi aplicado EDTA $17 \%$ para remoção da smear layer. O dentes foram divididos em 4 grupos:

1. grupo 1 - hidróxido de cálcio + solução salina normal;

2. grupo 2 - hidróxido de cálcio + água destilada;

3. grupo 3 - hidróxido de cálcio + propilenoglicol;

4. grupo 4 - hidróxido de cálcio + paramonoclorofenol canforado, 3,5:6,5. 
As soluções foram colocadas nos canais com auxílio de limas e os dentes selados na porção cervical e apical. As mensurações de pH e liberação de cálcio foram feitas nos períodos de 1, 3, 5, 7, 14, a 30 dias. Os grupos 2 e 4 proporcionaram os maiores valores de $\mathrm{pH}$ em relação aos grupos 1 e 3. A liberação de íons cálcio foi mais controlada e contínua no grupo 3. Os grupo 1, 2 e 3 promoveram a maior liberação em relação ao grupo 4. Para os autores, o propilenoglicol induziu liberação iônica mais favorável.

ESBERARD et $a l^{18}$ (1996), avaliaram a alcalinização proporcionada por pastas à base de hidróxido de cálcio em diferentes veículos. Foram utilizados neste estudo, dez incisivos laterais superiores, treze caninos superiores e inferiores, doze premolares inferiores e cinco incisivos centrais superiores. Após o preparo biomecânico e remoção da smear layer com EDTA, os canais foram secos, com cones de papel e aplicadas as pastas no interior dos canais, com auxilio de brocas lentulo. Na superfície externa da raiz foram confeccionadas cavidades de $1,5 \mathrm{~mm}$ de diâmetro e $0,75 \mathrm{~mm}$ de profundidade, nos terços cervical, médio e apical. As pastas utilizadas foram:

$\checkmark$ Grupo A - Hidróxido de Cálcio em veículo aquoso;

$\checkmark$ Grupo B - Hidróxido de Cálcio com paramonoclorofenol canforado;

$\checkmark$ Grupo C - Pulpodent paste;

$\checkmark$ Grupo D - Controle sem Hidróxido de Cálcio. 
Os dentes foram totalmente impermeabilizados, com exceção da área das cavidades. E os espécimes foram colocados em frascos individuais, contendo solução salina tamponada. $\mathrm{O} \mathrm{pH}$ das cavidades foi medido com o auxílio de um microeletrodo, nos seguintes períodos: $0,3,7,14,21,28,45,60,90$ e 120 dias. Os valores obtidos foram: Grupo controle pH 7,6 e 8,0 após três dias. Esse aumento ocorreu provavelmente pela difusão do hipoclorito de sódio 2,5\% através da dentina. Já durante os 18 dias seguintes o pH decaiu gradualmente até 6,7. No terço cervical os três grupos experimentais tiveram alterações de $\mathrm{pH}$ similares: pH 7,8 no início e após três dias já estava acima de 9. O grupo B promoveu o maior aumento de $\mathrm{pH}$ entre as pastas testadas, $\mathrm{pH}$ 10,6 após 3 dias de aplicação da pasta, com diferença estatisticamente significante em relação aos grupos A e C; no terço médio os resultados foram semelhantes ao terço cervical; no terço apical os grupos A e B tiveram comportamento semelhante, com diferença estatisticamente significante em relação ao grupo C. Tendo o grupo A valores ligeiramente superiores em relação ao grupo B. Diante dos resultados os autores concluíram que a difusão do hidróxido de cálcio nos terços cervical e médio é bem mais rápida que no terço apical, provavelmente devido ao maior número e maior calibre dos túbulos dentinários.

FUSS et $a l^{28}$ (1996), pesquisaram a influencia do $\mathrm{CO}_{2}$ no $\mathrm{pH}$ de canais preenchidos com pastas de hidróxido de cálcio. Sessenta dentes foram instrumentados, o cemento foi removido com brocas na superfície vestibular e 
lingual e procedeu-se ataque ácido interno e externo nos dentes. Foram aplicados nos canais seis tipos de pastas:

1. Calxyl;

2. Hydrocalcium;

3. Hidróxido de cálcio p.a associado à água destilada;

4. Hidróxido de cálcio p.a associado ao paramonoclorofenol canforado;

5. Hidróxido de cálcio p.a associado a anestésico;

6. Hidróxido de cálcio p.a associado a solvidont.

$\mathrm{O}$ pH das pastas foi conferido antes da colocação no interior dos canais, utilizando $0,022 \mathrm{~g}$ do produto testado associado a $4 \mathrm{ml}$ de água. As pastas foram levadas ao interior dos canais com o auxilio de brocas lentulo a condensadores digitais. Após o selamento coronário os dentes foram colocados individualmente em frascos, contendo $10 \mathrm{ml}$ de água destilada. Cinco dentes de cada grupo experimental foram expostos ao ar, à temperatura ambiente, os outros cinco dentes foram mantidos em câmara de $\mathrm{CO}_{2}$ por 30 dias. Após esse período os dentes foram reabertos e as pastas cuidadosamente removidas do interior dos canais radiculares e, $0,022 \mathrm{~g}$ dos resíduos removidos dos canais, foi associado a $4 \mathrm{ml}$ de água. Com base nos dados, verificou-se que não houve diferença estatisticamente significante entre o $\mathrm{pH}$ das diferentes pastas de hidróxido de cálcio. A exposição das pastas ao $\mathrm{CO}_{2}$ promoveu uma diminuição do $\mathrm{pH}$, com diferença estatisticamente significante em relação à não exposição ao $\mathrm{CO}_{2}$. Já 
em relação as diferentes pastas não houve diferença estatisticamente significante entre elas.

GOMES et $a l^{31}$ (1996), avaliaram a difusão de hidróxido de cálcio através da dentina. Os dentes selecionados para o experimento foram instrumentados e a smear layer removida pela aplicação de ácido cítrico por 30s. O experimento foi dividido em 3 fases. A primeira fase foi considerada a fase de dissolução: os dentes não receberam hidróxido de cálcio nos canais e cada dente foi selado na porção apical e coronária, em seguida armazenados em $700 \mathrm{ml}$ de água deionizada. Até que a liberação de cálcio dos dentes fosse estabilizada, após 15 mensurações. A segunda fase foi denominada, fase de dissolução e difusão I: os canais foram preenchidos com pasta de hidróxido de cálcio e solução salina, selados como na fase anterior e retornados a solução de água deionizada. A terceira fase foi chamada fase de dissolução e difusão II: espécimes foram divididos em 3 grupos, grupo 1 (controle) contendo a pasta original; grupo 2, no qual a pasta existente foi diluída, os dentes foram selados e imersos na solução; e o grupo 3, no qual a pasta existente foi removida e uma pasta nova foi colocada nos canais e, os dentes selados e imersos na solução. Sete mensurações foram realizadas para verificação da liberação de íons cálcio, no período de 504h. A difusão foi maior no grupo 3; seguido do grupo 2 e no grupo controle a difusão de cálcio foi estatisticamente nula. Os resultados mostraram que houve 
difusão de íons cálcio nos primeiros 16 dias, em todas as situações em que havia pasta de hidróxido de cálcio no interior dos canais radiculares.

GUIGNES et $a l^{36}$ (1996), verificaram a relação entre preparações endodônticas e a permeabilidade dentinária humana medida "in situ". Foram utilizados três grupos de 10 terceiros molares, apresentando canais com mínimas curvaturas. Foram realizados preparos com limas manuais tipo Kerr e Hedströen e irrigação com hipoclorito de sódio 2,5\%; preparo ultrasônico e preparo manual com irrigação final com EDTA 17\%. Foi feita análise por microscopia eletrônica de varredura, para se verificar correlações entre permeabilidade e quantidade de smear layer e debris orgânicos, recobrindo os túbulos dentinários. A permeabilidade foi medida especificamente por um aparelho composto por uma câmara pressurizada, um sistema de fixação e um sistema da mensuração, capaz de verificar a capilaridade dentinária, após os diferentes tratamentos. Foi possível verificar que o EDTA associado ao hipoclorito de sódio proporcionou um significante aumento na permeabilidade dentinária, seguido do ultra-som levemente inferior ao EDTA.

BELTES et $a l^{7}$ (1997), observaram a liberação de íons hidroxila in vitro de 6 tipos de pastas de hidróxido de cálcio: Calasept, Calcicur, Calxyl blue, Calxyl red, Reogan rapid, Temp canal. As pastas foram espatuladas e os períodos de verificação do $\mathrm{pH}$ foram: 0,$5 ; 1,1,5 ; 1,75 ; 2,8 \mathrm{~h}$ e $1,2,3,4$ dias. Os mais 
potentes alcalinizadores nos períodos testados foram: Reogan rapid, Calxyl red e Calcicur.

GUIGAND et $a l^{35}$ (1997), estudaram in vitro a difusão intra-dentinária de íons cálcio, utilizando dentes de porcos e dois materiais: hidróxido de cálcio adicionado à água destilada e óxido de cálcio 66,7\% + óxido de zinco 33,3\% em água glicosada. Após o preparo dos canais, as pastas foram colocadas no interior dos canais radiculares e as aberturas coronárias seladas. Os espécimes foram incubados separadamente, em umidade e sob anaerobiose. Em intervalos de: 8, 15 e 21 dias. Após esses períodos os dentes foram incluídos em resina epóxica e por testes microanalíticos em microscopia eletrônica de varredura, tanto o hidróxido de cálcio como o óxido de cálcio, liberaram íons cálcio através dos túbulos dentinários.

SIQUEIRA; LOPES $^{76}$ (1997), realizaram uma revisão sobre as supostas comprovações científicas do uso do hidróxido de cálcio. Em relação à ação antinflamatória a atividade higroscópica do hidróxido de cálcio deve-se ao fato dele ser hipertônico tendo a capacidade de absorver fluidos, reduzindo a pressão hidrostática tecidual. Quanto à formação de pontes de proteinato e inibição da fosfolipase $A_{2}$, não existem comprovações científicas. A ação antimicrobiana está associada a diversos fatores: perda da integridade de membrana citoplasmática bacteriana, inativação enzimática, dano ao DNA bacteriano, neutralização de endotoxinas, todos com comprovação científica. Também tem 
propriedade de dissolver matéria orgânica, que apesar de lenta, potencializa o uso do hipoclorito de sódio. Indução de reparo por tecido mineralizado: ativação da fosfatase alcalina, $\mathrm{Ca}^{+2}-$ ATPase e pirofosfatase cálcio dependente, com mecanismos de ação ainda não completamente elucidados.

ALAÇAM et $a l^{1}$ (1998), verificaram as variações do $\mathrm{pH}$ da dentina pela a administração de dois diferentes veículos para o hidróxido de cálcio. Nesse estudo foram utilizados 140 dentes humanos extraídos com uma só raiz que receberam preparo biomecânico $1 \mathrm{~mm}$ aquém do ápice, até o instrumento tipo Kerr número 50 e foram irrigados durante todo preparo com hipoclorito de sódio 5,25\%. A smear layer foi removida com irrigação final de EDTA trissódico $17 \%$ por $4 \mathrm{~min}$. Foram feitas fenestrações de $5 \mathrm{~mm}^{2}$ nas faces distal e mesial nos terços cervicais dos dentes. Os canais e as fenestrações foram copiosamente irrigados com água destilada para a remoção do excesso de EDTA. Os canais foram secos com cones de papel absorvente e os dentes divididos em 2 grupos:

1. No grupo 1: as pastas colocadas nos canais com $0,0536 \mathrm{~g}$ de $\mathrm{Ca}(\mathrm{OH})_{2}$ adicionados a $0,0744 \mathrm{ml}$ de água destilada;

2. No grupo 2, 0,0536g de $\mathrm{Ca}(\mathrm{OH})_{2}$ adicionados a $0,445 \mathrm{ml}$ de glicerina. Nos dois grupos foram utilizadas brocas lentulo para colocação das pastas no interior dos canais. Os dentes foram totalmente impermeabilizados, com três camadas de esmalte de unhas e cera pegajosa, exceto na área da fenestração. Cada dente foi separadamente estocado em frascos tampados, contendo $5 \mathrm{ml}$ de 
água destilada, à $37^{\circ} \mathrm{C}$ e, as medições de $\mathrm{pH}$ foram realizadas nos $5 \mathrm{ml}$ de água destilada, com o auxílio de um pHmetro. Nos períodos de: 1, 4, 7 e 12 dias. Após esse período os dentes foram seccionados ao meio, no sentido longitudinal, à distância entre as fenestrações e a parede do canal foram medidas. Três parâmetros foram avaliados: material, tempo e espessura da dentina. Não houve diferença estatisticamente significante entre os grupos, tendo a água destilada e a glicerina o mesmo comportamento na modificação do pH da dentina no período de tempo de 12 dias.

ÇALT et $a l^{12}$ (1999), pesquisaram as alterações de $\mathrm{pH}$ em defeitos, com $3 \mathrm{~mm}$ de diâmetro por $1 \mathrm{~mm}$ de profundidade, criados na superfície externa da raiz de 28 dentes apresentando um único canal radicular. Os canais foram instrumentados a smear layer, foi removida com o uso de EDTA $17 \%$ e os dentes foram impermeabilizados, exceto na cavidade externa da raiz. Os dentes foram divididos em quatro grupos e os canais preenchidos com as seguintes pastas:

1. DT temporary dressing $\mathrm{Ca}(\mathrm{OH})_{2}$ (Dental Therapeutics $\mathrm{AB}$, Nacka, Sweden);

2. Hidróxido de Cálcio em pó (Merck, Germany), 1,0g + 1ml de solução salina normal;

3. TempCanal (Pulpodent Corp., Watertown, MA);

4. Pontas de Hidróxido de Cálcio (Roeko D, Langenau, Germany). 
Os dentes foram colocados separadamente em frascos contendo $10 \mathrm{ml}$ de solução salina. As concentrações de íons cálcio e hidroxila foram medidas em: 1, 3, 7, 14 e 28 dias. As pastas de hidróxido de cálcio liberaram íons cálcio gradativamente, o que não foi observado com as pontas de hidróxido de cálcio. $\mathrm{O}$ aumento de $\mathrm{pH}$ não foi observado neste trabalho, provavelmente devido ao efeito tampão da dentina; segundo os autores isso pode ocorrer quando doadores de prótons $\left(\mathrm{H}_{2} \mathrm{PO}_{4}^{-}, \mathrm{H}_{2} \mathrm{CO}_{3}\right.$ e $\left.\mathrm{HCO}_{3}^{-}\right)$presentes na camada hidratada da hidroxiapatita, fornecem prótons adicionais para manter o $\mathrm{pH}$ inalterado, funcionando como um tampão. Os íons hidroxila também podem ser absorvidos por essa camada hidratada, diminuindo sua velocidade de difusão pelos túbulos dentinários; e ainda sendo a solubilidade do hidróxido de cálcio em água muito limitada e a quantidade de íons hidroxila liberada insignificante, estes íons são neutralizados e acumulados nas paredes do canal radicular, impedindo a transferência de novos íons hidroxila.

FAVA; SAUNDERS ${ }^{25}$ (1999), realizaram uma revisão da literatura classificando e indicando as diferentes pastas à base de hidróxido de cálcio. Iniciando as pesquisas com os trabalhos de Hermann em 1920, o qual conseguiu excelentes resultados clínicos e radiográficos de reparação com a pasta idealizada por ele, denominada Calxyl. Mesmo nos dias atuais o mecanismo de ação do hidróxido de cálcio ainda não está completamente compreendido, existindo inúmeros artigos publicados descrevendo propriedades 
antimicrobianas e antinflamatórias, indução de reparação e outras ações, que normalmente estão relacionadas à dissociação dos íons cálcio e hidroxila, que permeiam através da dentina. Quanto às características químicas do hidróxido de cálcio, este material é oriundo de rochas compostas por carbonato de cálcio $\left(\mathrm{CaCO}_{3}\right)$, formado quando esta solução existente nas águas do mar e das montanhas se cristaliza. A combustão dessa rocha entre 900 e $1200^{\circ} \mathrm{C}$, leva a reação:

$\mathrm{CaCO}_{3} \rightarrow \mathrm{CaO}+\mathrm{CO}_{2}$

O óxido de cálcio formado tem capacidade corrosiva em contato com a água causando a reação:

$\mathrm{CaO}+\mathrm{H}_{2} \mathrm{O} \rightarrow \mathrm{Ca}(\mathrm{OH})_{2}$

O hidróxido de cálcio é um pó branco inodoro, de peso molecular 74,08, apresenta baixa solubilidade em água $\left(1,2 \mathrm{gL}^{-1}\right.$ à $25^{0} \mathrm{C}$ - aumenta com o aumento da temperatura) o que é favorável clinicamente, permitindo uma ação por períodos maiores. Quimicamente é classificado como uma base forte. Sua ação está relacionada à liberação dos íons cálcio e hidroxila, como já foi dito. Entretanto quando os íons cálcio $\left(\mathrm{Ca}^{+2}\right)$ se combinam com o dióxido de carbono $\left(\mathrm{CO}_{2}\right)$ nos tecidos, forma-se o composto de carbonato de cálcio $\left(\mathrm{CaCO}_{3}\right)$, reduzindo sua atividade, pelo consumo dos íons cálcio, pela ineficácia do carbonato de cálcio com agente antimicrobiano e de reparação. A associação 
hidróxido de cálcio a um veículo apropriado, origina uma pasta alcalina, que pode ter as seguintes características:

1. Compostas principalmente por hidróxido de cálcio, o qual pode ser associado a outras substâncias para melhorar suas propriedades físicoquímicas como: radiopacidade, escoamento e consistência;

2. Não possuir presa ou endurecimento;

3. Pode se tornar solúvel ou ser reabsorvida em tecidos vitais, rapidamente ou lentamente dependendo do tipo do veículo utilizado;

4. Pode ser preparada na hora ou estar disponível preparada.

5. Nos canais radiculares é utilizada como curativo temporário e não como material definitivo de preenchimento.

Ressaltam ainda quais os tipos de veículos e qual a sua importância. O veículo determina a velocidade de dissociação do hidróxido de cálcio em íons cálcio e hidroxila, determinando a capacidade de solubilização e reabsorção da pasta nos tecidos apicais. As características de um veículo ideal são:

1. Permitir a lenta e gradual liberação de íons cálcio e hidroxila;

2. Permitir baixa difusão nos tecidos com baixa solubilidade nos fluidos teciduais;

3. Não possuir efeito adverso na indução de deposição de tecido duro.

Em geral 3 tipos de veículos são utilizados: 
1. Aquoso - solúvel em água, dissociação rápida dos íons cálcio e hidroxila, possui alto grau de solubilidade em contato com os tecidos apicais e fluidos teciduais, sendo reabsorvidos por macrófagos. Tem menor tempo de ação necessitando de trocas mais freqüentes. Exemplos (água, solução salina, Solução de Ringer, Suspensão aquosa de metilcelulose ou carboximetilcelulose e solução de detergente aniônico, solução anestésica e outros). Indicações: necessidade de modificações rápidas do $\mathrm{pH}$, traumatismos, urgências.

2. Viscoso - Alguns são solúveis em água, liberam mais lentamente os íons cálcio e hidroxila, possuindo uma atividade mais duradoura necessitando menor número de trocas, isso provavelmente devido ao maior peso molecular destes veículos, que minimiza a dispersão do hidróxido de cálcio, atuando de 2 a 4 meses. Exemplos (Glicerina, propilenoglicol, polietilenoglicol). Indicações: Necessidade de liberação lenta, trocas periódicas (menor número de trocas), em lesões extensas, apicificação.

3. Óleos - Não são solúveis em água, promovendo baixa solubilidade e difusão nos tecidos, tendo seu uso clínico comprometido. Exemplos (Óleo de Oliva, Óleo de Silicone, Cânfora, Metacresilacetato e alguns ácidos gordurosos tipo Ácido Oléico, Linoléico e Isosteárico).

As principais marcas comerciais são as seguintes:

Veículos aquosos: 
$\checkmark$ Calxyl (Otto ; Co. Frankfurt, Gremany)

$\checkmark$ Pulpodent (Pulpodent Corp., Brookline, M.A. USA)

$\checkmark$ Tempcanal (Pulpodent Corp., Brookline, M.A. USA)

$\checkmark$ Calvital (Neo Dental Chemical Products Co., Tokyo, Japan)

$\checkmark$ Reogan (Vivadent, Schaan, Liechtenstein)

$\checkmark$ Calasept (Scania Dental A.B., Knvista, Sweden)

$\checkmark$ Hypocal (Ellinam Co., Hewlatt, N,Y. USA)

$\checkmark$ Calcicur (VOCO, Auxhaven, Germany)

$\checkmark$ DT Temporary Dressing (Dental Therapeutics A.B., Nacka Sweden)

$\checkmark$ Calcipulpe (Specialités Septodont, Saint-Maur, France)

$\checkmark$ Hidropulp (Lab. Zizine, France)

$\checkmark$ Serocalcium (Casa Wild, Basel, Switzerland)

$\checkmark$ Calnex (Associated Dental Products, London, UK)

$\checkmark$ Calcigel (Lab. Septodont, France)

$\checkmark$ Endocal (Lab. Biodica, France)

$\checkmark$ Hydroxine (Lab. Ato Zizine, France)

$\checkmark$ Acrical (Barnes-Hind Laboratories, USA)

Veículos Viscosos:

$\checkmark$ Calen (S.S. White - R.J., Brasil)

$\checkmark$ Calen PMCC (S.S. White - R.J., Brasil)

Veículos Oleosos: 
$\checkmark$ Endoapex (Lab, Inadon Ltda, R.S, Brasil)

$\checkmark$ L;C (Herpo Prod. Dentários Ltda., R.J. Brasil)

$\checkmark$ Vitapex (NeoDental Chemical Products Co. Tokyo, Japan)

FAVA et $a l^{24}$ (2000), realizaram uma revisão sobre as soluções de hidróxido de cálcio ressaltando suas indicações em diversas associações: água de cal, com agente hemostático ou como solução irrigadora; hidróxido de cálcio + detergente que permite o contato mais rápido e intimo da solução com os resíduos da parede dentinária; água de cal + detergente melhorando o poder antimicrobiano da solução pela diminuição da tensão superficial da água de cal e aumentando seu poder antimicrobiano, e outras diversas indicações.

LARSEN; BINDSLEV ${ }^{52}$ (2000), avaliaram in vitro a liberação de íons hidroxila de vários produtos à base de hidróxido de cálcio, em canais simulados com tubos de polietileno (com $48 \mathrm{~mm}$ de comprimento e $2 \mathrm{~mm}$ de diâmetro e volume interno de $150,9 \mu 1)$. Os produtos testados foram:

a) Pontas de guta-percha à base de hidróxido de cálcio (Roeko, Langenan, Germany)

b) Calcicur paste (Voco, Cuxhaven, Germany)

c) $5 \mathrm{~g}$ de $\mathrm{Ca}(\mathrm{OH})_{2}+3,8 \mathrm{~g}$ de água destilada (Merk, Darmtadt, Germany)

As pastas de hidróxido de cálcio tiveram valores de $\mathrm{pH}$ significantemente superiores a guta-percha contendo hidróxido de cálcio. 
MURRAY et $a l^{59}$ (2000), estudaram a influência do tamanho das partículas na liberação de íons hidroxila, de produtos à base de hidróxido de cálcio. Os cimentos Life (Kerr, Romulus, MI. USA) e Dycal (Caulk Dentsply, Melford, DE, USA) as pastas Hypocal (Elleman, New York, NY, USA) e Calasept (Scania Dental, Stockholm, Sweden), foram espatulados, colocados dentro de tubos de teflon e imersos em água destilada, para aferição do $\mathrm{pH}$, nos períodos de $1,2,3,4,6$ e 8 h e 1 vez ao dia durante 14 dias, à temperatura ambiente. Os resultados mostraram uma liberação de íons hidroxila três vezes menor nos cimentos em relação às pastas, podendo o tamanho das partículas influenciar na alteração de $\mathrm{pH}$ de produtos à base de hidróxido de cálcio.

ÖZCELIK et $a l^{63}$ (2000), compararam a tensão superficial do hidróxido de cálcio misturado com diferentes veículos. Foram utilizados quatro veículos misturados ao hidróxido de cálcio em pó, na proporção 1:2. Foi utilizada a glicerina, solução anestésica dental (citanest - octapresin 3\%; Astra, Sweden), Solução de Ringer e solução salina isotônica. A tensão superficial ou interfacial das pastas e dos veículos foi verificada utilizando um tensiometro, "Du Noüy tensiometer" (Cambridge Industrial Intruments, London, UK). Os resultados mostraram diferenças estatisticamente significantes, entre os veículos e as pastas. A solução de Ringer e a solução salina isotônica proporcionaram os maiores valores de tensão do líquido e da pasta seguido da glicerina e, a solução anestésica mostrou a menor tensão superficial entre os veículos. 
PÉCORA et al ${ }^{65}$ (2000), avaliaram a permeabilidade dentinária após instrumentação do canal radicular e aplicação de laser de Er:YAG. Vinte e cinco dentes humanos unirradiculados extraídos foram divididos em 5 grupos:

$\checkmark$ grupo 1 - instrumentação e utilização de água deionizada como solução de irrigação;

$\checkmark$ grupo 2 - instrumentação e utilização de hipoclorito de sódio $1 \%$ como solução de irrigação;

$\checkmark$ grupo 3 - instrumentação e utilização de água deionizada como solução irrigadora e aplicação de laser;

$\checkmark$ grupo 4 - instrumentação e utilização de hipoclorito de sódio $1 \%$ como solução de irrigadora e aplicação de laser;

$\checkmark$ grupo 5 - instrumentação apenas até o instrumento número 20 e aplicação laser, usando água deionizada como solução irrigadora.

O laser foi aplicado a $15 \mathrm{~Hz}, 140 \mathrm{~mJ}$, total de energia de $42 \mathrm{~J}, 300$ pulsos. Sulfato de cobre $10 \%$ foi utilizado para verificar a permeabilidade dentinária. O uso do laser de Er:YAG promoveu um aumento na permeabilidade dentinária, principalmente quando associado à água deionizada.

SAFAVI; NAKAYAMA ${ }^{67}$ (2000), pesquisaram a influência do veículo de administração do hidróxido de cálcio na dissociação da solução. Foram utilizados três veículos para realização do experimento: glicerina, propilenoglicol e água pura. Os veículos foram associados ao pó de hidróxido de 
cálcio e as pastas testadas quanto à condutividade, a temperaturas de $23,30 \mathrm{e}$ $37^{\circ} \mathrm{C}$. A condutividade dos veículos não aquosos, glicerina e propilenoglicol, foi próxima a zero e aumentou com a adição de água à pasta. Ressaltando os autores que o uso de veículos não aquosos pode impedir a efetividade do hidróxido de cálcio como medicamento intracanal.

SCHÄFER et $a l^{71}$ (2000), avaliaram as alterações no $\mathrm{pH}$ da dentina radicular após curativo intracanal com pontas de guta-percha, contendo hidróxido de cálcio. Cento e vinte dentes foram instrumentados e medicados com cones de guta-percha, contendo hidróxido de cálcio, equivalente a uma suspensão aquosa, por períodos de $24 \mathrm{~h}, 3$ ou 7 dias. Os dentes foram seccionados longitudinalmente e o $\mathrm{pH}$ medido com um microeletrodo colocado em contato com as pequenas cavidades feitas na superfície radicular. No período testado os cones de guta-percha contendo hidróxido de cálcio foram incapazes de alcalinizar a dentina.

VONGSAVAN et al ${ }^{88}$ (2000), compararam a permeabilidade dentinária in vivo e in vitro. Foram utilizados 6 pacientes com indicação de exodontia dos 2 premolares superiores, por motivos ortodônticos. Os pacientes foram anestesiados e dois procedimentos foram realizados em um dos premolares de cada paciente: 
1. Desgaste da cúspide vestibular com broca diamantada em alta rotação e, colagem de um cilindro de acrílico com cimento Lyfe. Em seguida foi aplicada solução de azul de Evans.

2. Confecção de um sulco transversal na cúspide vestibular seguida da fratura da cúspide com um cinzel e, colagem do cilindro da mesma citada acima e aplicação de azul de Evans.

Os dentes contra-laterais foram extraídos e uma hora após foi realizado o mesmo experimento descrito in vivo. Os resultados mostraram média de infiltração em milímetros: in vivo - 2,9 e in vitro - 1,9, sem diferença estatisticamente significante. Houve falha na penetração do corante em dois dentes do grupo in vitro, mostrando ainda que muitos estudos devem ser realizados para esclarecer o comportamento do fluido dentinário nas duas condições.

HOSOYA et $a t^{46}$ (2001), avaliaram a concentração de cálcio e o pH da região periapical, após a aplicação de hidróxido de cálcio no interior de canais radiculares in vitro. Cinqüenta canais simulados em resina epóxica (possuindo um orifício apical de $0,6 \mathrm{~mm}$ de diâmetro), foram divididos em 4 grupos:

$\checkmark$ Grupo 1 - receberam medicação de hidróxido de cálcio associado à água destilada em $38 \%$;

$\checkmark$ Grupo 2 - receberam medicação de hidróxido de cálcio associado à água destilada em 44\%; 
$\checkmark$ Grupo 3 - receberam medicação de hidróxido de cálcio associado à água destilada em $50 \%$;

$\checkmark$ Grupo 4 - receberam medicação de hidróxido de cálcio em pó (Próanálise);

$\checkmark$ Grupo 5 - controle sem hidróxido de cálcio.

Os corpos de prova foram imersos em $10 \mathrm{ml}$ de água destilada e incubados à $37^{\circ} \mathrm{C}$, o pH e a quantidade de cálcio liberada foram medidos aos 3 e 7 dias e semanalmente até completar 15 semanas. A quantidade de cálcio liberada foi verificada por espectrofotometria da solução que os corpos de prova estavam imersos e, o pH pela modificação da cor da água destilada para vermelho, pela reação de um corante com o hidróxido de cálcio. Os grupos 1 ao 3 proporcionaram os maiores valores de $\mathrm{pH}$ e concentrações de cálcio, no grupo 4 os maiores valores foram no sétimo dia. $\mathrm{O}$ pico de $\mathrm{pH}$ foi verificado no $14^{\circ}$ dia para os grupo de 1 a 3 e no $49^{\circ}$ dia para o hidróxido de cálcio em pó. Sugerindo os autores que um bom período para permanência do hidróxido de cálcio é de 2 semanas.

CÁRDENAS et $a l^{13}$ (2001), verificaram a influência das trocas de diferentes pastas de hidróxido de cálcio na alcalinização da superfície radicular de dentes humanos recém extraídos. Os canais foram preparados e receberam medicação com pastas de hidróxido de cálcio, com dois veículos: água bidestilada e polietilonoglicol 400 , adicionado a $0,15 \mathrm{ml}$ de paramonoclorofenol 
canforado (PMCC) ou tricresol formalina. $\mathrm{O} \mathrm{pH}$ foi verificado em diferentes períodos de tempo: 1h, 3, 7, 14, 21, 30, 60, 90, 120 dias. Em alguns dentes foram feitas trocas das pastas no final de 14, 30, 60 e 90 dias. $\mathrm{O} \mathrm{pH}$ foi medido em cavidades criadas na superfície externa das raízes na porção cervical, média e apical. Os resultados permitiram concluir que o hidróxido de cálcio difunde pelos túbulos dentinários, alcalinizando a superfície radicular. Não houve diferença estatisticamente significante entre os grupos, porém as trocas periódicas de medicação mostraram um ligeiro aumento no pH em relação aos outros grupos, sendo que as trocas realizadas próximo ao $30^{\circ}$ dia mostraram melhores resultados.

MIÑANA et $a l^{58}$ (2001), avaliaram as alterações no $\mathrm{pH}$ da superfície radicular da dentina cervical e apical, após a colocação de curativos intracanal com óxido de cálcio e hidróxido de cálcio. O efeito da exposição dos materiais ao $\mathrm{CO}_{2}$, também foi verificado neste trabalho. Trinta e seis caninos humanos extraídos foram selecionados e instrumentados. Duas cavidades com $1 \mathrm{~mm}$ de profundidade e 1,5mm de diâmetro foram confeccionadas uma na região apical e outra na cervical. Os dentes foram divididos em dois grupos e preenchidos com hidróxido de cálcio ou óxido de cálcio. $\mathrm{O}$ pH foi verificado a cada $24 \mathrm{~h}$ durante 18 dias e, após esse período foi aplicado $\mathrm{CO}_{2}$ nos frascos por $24 \mathrm{~h}$. $\mathrm{O} \mathrm{pH}$ foi medido novamente nos dias 53 e 68 . Os resultados mostraram um aumento similar do $\mathrm{pH}$ para ambos os materiais. Os valores de $\mathrm{pH}$ verificados foram: 
terceiro dia 10,3 a 10,$6 ; 18^{\circ}$ ao $48^{\circ}$ dia 9,2 a 9,5 . O valor do $\mathrm{pH}$ reduziu significantemente após a exposição dos espécimes ao $\mathrm{CO}_{2}$. Este estudo demonstrou que os íons hidroxila produzidos pelo óxido de cálcio se difundem de maneira similar aos liberados pelo hidróxido de cálcio.

SCHMALZ et $a l^{11}$ (2001) analisaram a permeabilidade da dentina humana e bovina sobre diferentes pré-tratamentos da dentina. Foram utilizados incisivos centrais bovinos, de animais entre 2 e 4 anos de idade e, terceiros molares humanos com completa formação radicular. Os dentes foram cortados em fatias de 100, 300, 500 e 700 $\mu$ m sobre irrigação em baixa rotação. Os dentes bovinos foram cortados longitudinalmente nas faces mesial e distal e, os dentes humanos foram cortados transversalmente, paralelamente à superfície oclusal. Em algumas fatias a smear layer foi removida com uso de ácido cítrico $50 \%$ e lavagem com soro fisiológico. Todas as fatias foram esterilizadas em autoclave por $25 \mathrm{~min}$ a $121^{\circ} \mathrm{C}$. Os cortes de dentina humana e bovina foram comparados quanto à condutância hidráulica $\left(\mathrm{L}_{\mathrm{p}}\right)$ e fluxo de difusão de água $\left(\mathrm{J}_{\mathrm{s}}\right)$. Os valores foram semelhantes para os dois tipos de dentina sem diferença estatisticamente significante. Já a permeabilidade aumentou com o ataque ácido. Verificou-se que a dentina bovina parece ser uma alternativa para trabalhos in vitro, devido à sua semelhança com a dentina humana quanto às características de permeabilidade transdentinária. 


\subsection{Ação antimicrobiana do hidróxido de cálcio:}

SUNDQVIST; SJÖGREN ${ }^{81}$ (1989), pesquisando a prevalência de bacterióides em infecções de canais radiculares também isolaram 91,4\% de bactérias anaeróbias nesse tipo de infecção.

BAUMGARTNER; FALKER ${ }^{6}$ (1991), pesquisaram as características das bactérias apicais em pacientes, portadores de lesões periapicais visíveis radiograficamente. Foram utilizados dez dentes de pacientes da clínica de urgência. $\mathrm{O}$ material foi colhido dos canais e avaliado quanto à aerobiose e anaerobiose; cinquienta espécies bacterianas foram identificadas, trinta e quatro delas anaeróbias (68\%), mostrando a importância da ação dos medicamentos sobre estas espécies que predominam nas alterações periapicais de longa duração.

SJÖGREN et $a l^{79}$ (1991), avaliaram os efeitos antimicrobianos do hidróxido de cálcio como curativo intracanal por curto período de aplicação. Trinta dentes unirradiculados com lesão periapical visível radiograficamente foram instrumentados, e para remoção da smear layer utilizou-se vibração ultrasônica. Dos 30 dentes 18 receberam medicação intracanal de Calasept por 1 semana, e 12 dentes receberam Calasept por 10 minutos. O medicamento foi removido do canal após esse período e colhido material para análise microbiológica. Os resultados mostraram que o uso do medicamento por 10 
minutos ou sete dias é pouco confiável para a eliminação das bactérias presentes no sistema de canais radiculares e massa dentinária.

STWART et $a l^{80}$ em 1991, compararam o efeito antimicrobiano do hidróxido de cálcio em veículo aquoso, em relação ao paramonoclorofenol e o formocresol; em canais contaminados in vitro, com Streptococcus mutans, Actinomyces viscosus e Bateroides gingivalis ou fragilis. Todos os medicamentos foram eficientes contra os microrganismos e a diferença estatística não foi significante.

BARBOSA et at (1994), associaram o hidróxido de cálcio ao detergente lauril-dietileno-glicoléter-sulfato de sódio $0,125 \%$ em água (tergentol $10 \%$ e tergentol 20\%) e, avaliaram sua ação antimicrobiana contra os seguintes microrganismos: Streptococcus faecalis, Streptococcus sanguis, Streptococcus mutans, Streptococcus salivarius, Neisseria sp., diphtheroid, Staphylococcus aureus, Lactobacillus sp., Staphylococcus epidermidis, Bacillus subtilis e Candida albicans. A solução saturada de hidróxido de cálcio foi efetiva contra 4 destes 11 microrganismos em 60min de exposição. As soluções de hidróxido de cálcio contendo detergente mataram todos os 11 microrganismos em 30min de exposição com diferença estatisticamente significante. Porém entre a associação de 10 ou $20 \%$ de tergentol a diferença não foi estatisticamente significante. Contudo a baixa tensão superficial e o alto pH da solução hidróxido de cálcio com tergentol $20 \%$ estabelecem uma solução mais efetiva. Fica caracterizado 
que a associação de detergente ao hidróxido de cálcio aumenta e acelera sua capacidade antimicrobiana.

SAFAVI; NICHOLS ${ }^{69}$ (1993), analisaram in vitro os efeitos do hidróxido de cálcio sobre os lipopolisacarídes (LPS) bacterianos, pela quantidade de ácidos gordurosos liberados após a interação do hidróxido de cálcio com os LPS. A análise foi feita por cromatografia a gás e em um espectrofotômetro de massa. Os resultados mostraram uma grande liberação de ácidos gordurosos após a reação, caracterizando uma hidrólise do lipídeo A (porção mais tóxica do LPS) proporcionada pelo hidróxido de cálcio. Sugerindo os autores que o hidróxido de cálcio degrada o LPS, mais um motivo favorável a seu uso clínico em Endodontia.

SAFAVI; NICHOLS ${ }^{68}$ (1994), considerando que o lipopolissacaríde exerce um papel importante na reabsorção óssea, e que o hidróxido de cálcio é capaz de degrada-lo, este trabalho tentou mostrar as alterações biológicas do hidróxido de cálcio sobre as propriedades químicas de LPS. Essa alteração biológica foi medida por secreção de prostaglandinas $\mathrm{E}_{2}$ de monócitos humanos. Culturas de monócitos humanos foram estimuladas por LPS ou hidróxido de cálcio tratado com LPS e a cultura sobrenadante foi analisada para prostaglandina $\mathrm{E}_{2}$, usando cromatografia a gás e em um espectrofotômetro de massa. Foram identificadas prostaglandinas $\mathrm{E}_{2}$ nas culturas sobrenadante de monócitos estimulados por LPS, e não foram identificadas nas culturas estimuladas com hidróxido de cálcio 
tratado com LPS. Concluindo que o hidróxido de cálcio pode afetar as propriedades biológicas do LPS bacteriano.

KONTAKIOTIS et $a t^{49}$ (1995), isolaram 40 tipos de microrganismos de canais radiculares infectados, destes 20 tipos anaeróbios estritos, que foram utilizados para o estudo da ação indireta do hidróxido de cálcio sobre a microflora do canal radicular. No grupo experimental os microrganismos foram incubados em câmara de anaerobiose semeados em Agar sangue e em uma placa ao lado havia $32 \mathrm{~g}$ de hidróxido de cálcio em pasta. No grupo controle não se incubou o hidróxido de cálcio junto aos microrganismos. Após 72h de incubação, as colônias foram recontadas e os resultados mostraram que no grupo experimental houve uma redução significativa no número de microrganismos em relação ao grupo controle; sugerindo os autores que: o hidróxido de cálcio provavelmente compete com os microrganismos pelo $\mathrm{CO}_{2}$, exercendo efeito bacteriostático, diminuindo o suprimento alimentar dos microrganismos.

BARBOSA et $a l^{5}$ (1997), avaliaram clinicamente e em laboratório a atividade antibacteriana do hidróxido de cálcio, clorexidina e paramonoclorofenol canforado (PMCC) como medicamento intracanal. No experimento clínico, canais que tinham cultura positiva, uma semana após o completo preparo biomecânico e curativo com PMCC, foram medicados com uma das três substâncias testadas, que permaneceram por 1 semana no interior dos canais. A inibição microbiana foi avaliada após esse período. No estudo 
laboratorial foi usado o teste de difusão em Agar. Os resultados clínicos mostraram que os medicamentos foram efetivos, reduzindo ou eliminando os microrganismos, pela verificação das culturas negativas. Não houve diferença estatisticamente significante entre os grupos. No estudo laboratorial o PMCC promoveu o maior halo de inibição no período de 7 dias sobre os microrganismos testados (A. isrelii, A.naeslundii, E. faecalis, F. nucleatum, P. endodontalis, P. gingivalis, P. acnes, P. aeruginosa, S. aureus, S. mutans.).

ESTRELA et $a l^{23}$ (1998), determinaram in vitro, o tempo necessário para o hidróxido de cálcio ter ação antimicrobiana, quando em contato direto com os microrganismos. Os microrganismos utilizados neste trabalho foram: Micrococcus luteus, Staphylococcus aureus, Fusobacterium nucleatum, Pseudomonas aeruginosa, Escherichia coli e Streptococcus sp, cultivados em BHI. Cones de papel imersos nas culturas de microrganismos foram recobertos por hidróxido de cálcio e após $0,1,2,6,12,24,48$ e 72 horas e 7 dias foram transferidas para um meio apropriado para observar o crescimento e multiplicação dos microrganismos. A incubação foi conduzida a $37^{\circ} \mathrm{C}$ por $48 \mathrm{~h}$. $\mathrm{O}$ efeito antimicrobiano do hidróxido de cálcio ocorreu após $12 \mathrm{~h}$ sobre o Micrococcus luteus e o Fusobacterium nucleatum, 24h sobre o Streptococcus sp, 48h para a Escherichia coli e 72h para o Staphylococcus aureus e Pseudomonas aeruginosa. Salientando os autores que a permeabilidade dentinária e o grau de 
calcificação influenciam a difusão dos íons pela dentina e afetam a modificação pH proporcionada pelo hidróxido de cálcio.

SIQUEIRA et $a l^{78}$ (1998), pesquisaram a capacidade de curativos à base de hidróxido de cálcio e de paramonoclorofenol canforado (PMCC) em impedir a recontaminação de canais radiculares que não tiveram suas aberturas coronárias seladas com cimento provisório. Cinqüenta e cinco dentes foram preparados e divididos em três grupos para receber a medicação intracanal:

1. PMCC - colocado na câmara pulpar (algodão embebido na solução);

2. Hidróxido de cálcio - veículo aquoso (solução salina);

3. Hidróxido de cálcio - veículo viscoso (glicerina) + PMCC.

As aberturas coronárias não foram seladas e na porção apical da raiz foi adaptada uma câmara contendo meio de cultura. Os canais foram deixados expostos à saliva até a completa contaminação. $\mathrm{O}$ curativo de $\mathrm{PMCC}$ permitiu a recontaminação dos canais radiculares em média em 6,8 dias; os canais medicados com hidróxido de cálcio em solução salina tiveram média de 14,7 dias para a recontaminação e os canais medicados com hidróxido de cálcio associado ao PMCC em glicerina se recontaminaram em 16,5 dias. Esse estudo mostrou que o hidróxido de cálcio promoveu um efetivo retardo na recontaminação dos canais radiculares.

ESTRELA et $a l^{21}$ (1999), pesquisaram os efeitos do veículo nas propriedades antimicrobianas das pastas de hidróxido de cálcio. Para realização 
do experimento, o hidróxido de cálcio foi associado a três diferentes veículos: solução salina, polietilenoglicol e solução anestésica. Esses veículos interferiram nas propriedades físicas de dissociação, difusão dos íons cálcio e hidroxila. Quando o hidróxido de cálcio é associado a veículos hidrossolúveis (água destilada e solução salina) há uma melhora no seu comportamento biológico, antimicrobiano e de indução de reparo tecidual.

ESTRELA et $a l^{22}$ (1999), avaliaram o efeito antimicrobiano do hidróxido de cálcio em túbulos dentinários infectados. Foram utilizados neste estudo 4 tipos de microrganismos: Streptococcus faecalis, Staphylococcus aureus, Bacillus subtilis e Pseudomonas aeruginosa, inoculados em meio BHI incubados à $37^{\circ} \mathrm{C}$ por $24 \mathrm{~h}$. Sessenta e três dentes humanos foram preparados e esterilizados em autoclave. Cinco grupos de 12 dentes foram contaminados por 28 dias e após esse período foi aplicado hidróxido de cálcio em solução salina no interior dos canais, nos intervalos de 0,48 e $72 \mathrm{~h}$ e 7 dias, os curativos foram removidos e os dentes imersos em $5 \mathrm{ml}$ de $\mathrm{BHI}$ e incubados por $48 \mathrm{~h}$ à $37^{\circ} \mathrm{C}$, para observar o crescimento e multiplicação dos microrganismos. Observando os resultados foi possível concluir que neste experimento, o hidróxido de cálcio não teve efeito antimicrobiano no interior dos túbulos dentinários, sobre os microrganismos testados.

SIQUEIRA; LOPES ${ }^{77}$ (1999), fizeram uma revisão crítica dos mecanismos de ação antimicrobiana do hidróxido de cálcio. A maior parte dos 
microrganismos relacionados a infecções endodônticas não sobrevive a $\mathrm{pH}$ alcalino, e a ação antimicrobiana principal do hidróxido de cálcio está relacionada à alcalinização da massa dentinária. Os íons hidroxila são altamente oxidantes de radicais livres que se mostram extremamente reativos, reagindo com muitas biomoléculas. Essa reatividade é alta e indiscriminada, então esses radicais livres raramente difundem longe dos sítios de geração. Seu efeito letal para as células bacterianas, ocorre provavelmente pelos seguintes mecanismos:

$\checkmark$ Dano à membrana citoplasmática da bactéria. Íons hidroxila induzem peroxidação lipídica resultando na destruição dos fosfolípedes da membrana, removendo átomos de hidrogênio de ácidos gordurosos insaturados, gerando radicais livres lipídicos que reagem com o oxigênio, formando um radical peróxido lipídico, que remove outro átomo de hidrogênio do segundo ácido gorduroso, gerando outro peróxido lipídico. Então os peróxidos agem como radicais livres, iniciando uma reação autocatalítica em cadeia e, resultando em futuros ácidos gordurosos insaturados e extensiva destruição da membrana bacteriana.

Desnaturação Protéica. Com a elevação do $\mathrm{pH}$ promovido pelo hidróxido de cálcio, há uma indução de quebra de adesão iônica que mantém a estrutura terciária da proteína, como consequiência à enzima permanece com sua estrutura covalente. Porém a cadeia polipeptídica toma configuração espacial irregular, com perda da atividade biológica da 
enzima e interrupção do metabolismo celular, pois esta não mais se encaixa em seu sítio de recepção. Proteínas estruturais também podem ser danificadas por íons hidroxila.

$\checkmark$ Dano ao DNA bacteriano. Os íons hidroxila reagem com o DNA bacteriano e induz o rompimento da fita dupla, genes são perdidos, como conseqüência à replicação celular é inibida e a atividade celular fica desorganizada. Os radicais livres também podem induzir mutações letais nas células.

A maioria das bactérias presentes nas infecções endodônticas sobrevive em $\mathrm{pH}$ de 8 a 9 exemplos: Escherichia coli, Proteus vulgares, Enterobacter aerogenes, Pseudomonas auriginosa e outras bactérias ocasionalmente isoladas em canais radiculares infectados. Bactérias como Enterococcus faecalis toleram pH entre 9 e 11, suportando excessivamente ambientes alcalinos. A resistência bacteriana a medicação pode ser influenciada pelos seguintes fatores:

1. Resistência intrínseca da bactéria;

2. Variações anatômicas que impedem o acesso às bactérias (túbulos dentinários, crateras de reabsorção etc...);

3. Neutralização do medicamento por componentes teciduais (efeito tampão da dentina etc..);

4. Tempo de contato insuficiente para que o medicamento tenha ação efetiva; 
5. Alteração do padrão genético da bactéria, após mudanças no meioambiente.

O veículo influencia na rapidez e efetividade da ação antimicrobiana, além do hidróxido de cálcio atuar como barreira física prevenindo a contaminação via coronária.

HAAPASALO et $a l^{37}$ (2000), estudaram a possível inativação de medicamentos utilizados na terapia intracanal pela dentina. $\mathrm{O}$ estudo consistia da obtenção de pó de dentina de terceiros molares, extraídos, limpos e esterilizados, obtendo partículas de 0,2 a $20 \mu \mathrm{m}, 28 \mathrm{mg}$ e $50 \mu 1$, pré-incubadas ou não, junto aos medicamentos à $37^{\circ} \mathrm{C}$ por $24 \mathrm{~h}$, ou $1 \mathrm{~h}$ antes de adicionar as bactérias (Enterococcus faecalis), ou simultaneamente. Os medicamentos testados foram:

1. $\mathrm{Ca}(\mathrm{OH})_{2}$ em pó saturado em água.

2. Hipoclorito de sódio $1 \%$

3. Acetato de Clorexidine 0,5 e $0,05 \%$

4. Iodine - potássio - iodine - (IKI) - 2/4\% e $0,2 / 0,4 \%$

A diluição foi feita em três partes: $50 \mu 1$ de medicamento, $50 \mu 1$ de pó de dentina e $50 \mu 1$ de bactérias. Amostras foram removidas das soluções nos períodos de 5min, $1 \mathrm{~h}$ e $24 \mathrm{~h}$ após a incubação com adição das bactérias. A dentina teve um efeito inibitório sobre os medicamentos, dependendo da concentração da solução e do tempo de pré-incubação da solução antes da adição das bactérias. Nos 
grupos sem adição de dentina as bactérias foram efetivamente mortas nos grupos experimentais. O hidróxido de cálcio perdeu totalmente o efeito sobre os microrganismos com a adição de dentina em pó. O IKI também teve seu efeito eliminado e tanto o hipoclorito como a clorexidine tiveram seus efeitos reduzidos.

LEONARDO et $a l^{54}$ (2000), avaliaram in vitro a atividade antimicrobiana de cimentos obturadores e pastas usadas em endodontia. Os cimentos utilizados foram: AH Plus, Sealapex, Ketac Endo e Fill Canal, as pastas à base de hidróxido de cálcio: Calen, Calasept e uma pasta de óxido de zinco. Os microrganismos utilizados no experimento foram: Micrococcus luteus, Staphylococcus aureus, Pseudomonas aeruginosa, Staphylococcus epidermides, Escherichia Coli e Enterococcus faecalis, e também Streptococcus mutans isolados da saliva. Os materiais foram testados pelo método de Agar difusão em pastas à base de hidróxido de cálcio e dois cimentos endodônticos. Colocados diretamente sobre os microrganismos, ou usando cones de papel absorvente. Mantidos por duas horas em temperatura ambiente, para difusão. Depois incubados por $24 \mathrm{~h}$ a $37^{\circ} \mathrm{C}$. Após isso os halos de inibição foram medidos. Todos os microrganismos foram inibidos por todos os materiais testados pelo método da colocação direta do material, já na aplicação dos materiais por cones de papel absorvente o Enterococcus faecalis não foi inibido pelo óxido de zinco, e o Pseudomonas aeruginosa não foi inibido pelo AH Plus, Fill Canal pasta de 
óxido de zinco. Contudo pode-se concluir que as pastas e cimentos testados possuem ação antimicrobiana contra os microrganismos testados.

BUCK et $a l^{8}$ (2001), pesquisaram a possibilidade da perda da toxicidade da endotoxina por irrigantes endodônticos e hidróxido de cálcio. A análise da ação do hidróxido de cálcio e dos irrigantes sobre a endotoxina foi feita por uma técnica altamente seletiva, por espectrometria/gás cromatografia monitoração iônica. Uma solução aquosa de lipopolissacarídeo (LPS; endotoxina) foi misturada a uma variedade de irrigantes endodônticos por 30min (água, EDTA, etanol, clorexidine $0,12 \%$, clorexidine +hipoclorito de sódio e hipoclorito de sódio sozinho). O hidróxido de cálcio foi também adicionado a solução de LPS pelo período de 1, 2 e 5 dias. A inativação do lipopolissacarídio foi mensurada pela quantidade de ácidos gordurosos livres liberados. A água, EDTA, etanol, clorexidine $0,12 \%$, clorexidine + hipoclorito de sódio e hipoclorito de sódio sozinho tiveram pouco efeito na inativação do LPS. O uso prolongado de hidróxido de cálcio bem como a exposição por 30min a uma mistura alcalina de clorexidine, etanol e hipoclorito de sódio, foram efetivos na neutralização das moléculas de LPS, pela hidrólise do lipídio A em ácidos gordurosos, menos tóxicos para o organismo.

ESTRELA et $a l^{20}$ (2001), determinaram a influência dos veículos associados ao hidróxido de cálcio na atividade antimicrobiana das pastas. Cones de papel foram imersos por $3 \mathrm{~min}$ em diferentes suspensões contendo 
microrganismos, em seguida os cones foram transferidos para placas de Petri e cobertos com curativos de hidróxido de cálcio em diferentes veículos: solução salina, paramonoclorofenol canforado, lauril sulfato de sódio a 3\% e otosporin; incubados por: $1 \mathrm{~min}, 48$ e $72 \mathrm{~h}$ e 7 dias. Os cones de papel foram removidos do contato com os curativos e imersos em $5 \mathrm{ml}$ de meios de cultura, novamente incubados por $48 \mathrm{~h}$, transferidos para o meio $\mathrm{BHI}$, incubados por mais $48 \mathrm{~h}$ e analisados quanto ao crescimento bacteriano. Os curativos de hidróxido de cálcio foram efetivos contra os microrganismos, logo após as primeiras $48 \mathrm{~h}$, independentemente do veículo utilizado.

HAN et $a l^{38}$ (2001), também pesquisaram a ação antimicrobiana do hidróxido de cálcio sobre o Enterococcus faecalis pelo período de 3 semanas após a remoção da smear layer. Os canais de dentes recém extraídos foram preparados, infectados com Enterococcus faecalis e divididos em quatro grupos para a colocação das medicações à base de hidróxido de cálcio:

a) hidróxido de cálcio em veículo aquoso - com remoção da smear layer

b) hidróxido de cálcio em óleo de silicone- com remoção da smear layer

c) hidróxido de cálcio em veículo aquoso - sem remoção da smear layer

d) hidróxido de cálcio em óleo de silicone- sem remoção da smear layer As pastas foram deixadas pelo período de 7 dias. Após esse período a medicação foi removida e pedaços de dentina foram coletados e incubados analisado-se o crescimento bacteriano. Todas as pastas foram efetivas em eliminar o 
Enterococcus faecalis presente nos túbulos dentinários, exceto nos canais que receberam medicação à base de hidróxido de cálcio em óleo de silicone sem remoção da smear layer.

\subsection{Capacidade de dissolução de matéria orgânica do hidróxido de cálcio:}

GORDON et $a l^{33}$ (1985), observaram os efeitos do hidróxido de cálcio sobre o tecido pulpar bovino, verificando as variações de $\mathrm{pH}$ e da concentração de cálcio. Os tecidos pulpares bovinos foram tratados com hidróxido de cálcio e hidróxido de bário saturados. Esses tecidos foram examinados quanto à atividade enzimática residual e a modificação de proteínas solúveis. No experimento in vitro os dois materiais inibiram as enzimas fosfatase alcalina e deidrogenáse láctica, porém o hidróxido de cálcio em $\mathrm{pH}$ um pouco inferior ao seu máximo, pH 10, foi significativamente menos inibitório; além de sua ação não ser excessivamente tóxica graças a sua baixa solubilidade.

HASSELGREN et $a l^{40}$ (1988), compararam os efeitos do hidróxido de cálcio e do hipoclorito de sódio na dissolução de tecido muscular necrótico de porcos. Foram cortados blocos de $2 \times 1 \times 1 \mathrm{~mm}$ do tecido muscular congelado, foi registrado o peso de todas as peças e utilizadas dez peças em cada grupo.

$\checkmark$ Grupo 1 - 20ml de hidróxido de cálcio em água $0,6 \mathrm{~g} / \mathrm{ml}$

$\checkmark$ Grupo 2 - 20ml de hipoclorito de sódio 0,5\% 
$\checkmark$ Grupo $3-20 \mathrm{ml}$ de hipoclorito de sódio $0,5 \%$, trocado a cada $30 \mathrm{~min}$ até a completa dissolução

$\checkmark$ Grupo $4-20 \mathrm{ml}$ de hidróxido de cálcio em água, transferidos para o hipoclorito de sódio $0,5 \%$, após $30 \mathrm{~min}$

$\checkmark$ Grupo $5-20 \mathrm{ml}$ de hidróxido de cálcio em água, transferidos para o hipoclorito de sódio $0,5 \%$, após $24 \mathrm{~h}$

$\checkmark$ Grupo $6-20 \mathrm{ml}$ de hidróxido de cálcio em água, transferidos para o hipoclorito de sódio $0,5 \%$, após 7 dias

$\checkmark$ Grupo 7 - (controle), 20ml de solução salina

As peças foram repesadas, 30, 60 e $90 \mathrm{~min}, 10$ e $24 \mathrm{~h}$. Os resultados quanto ao tempo levado para a dissolução completa das peças foram: Grupo 1 - 12 dias; Grupo 2 - não dissolveu; Grupo 3 - 180min, Grupo 4 - 90min, Grupo 5 60min, Grupo 6 - 60min, Grupo 7 - não dissolveu. Esse trabalho demonstrou a importância da renovação da solução do hipoclorito de sódio e o uso conjugado dessa solução com o hidróxido de cálcio, potencializando a ação da primeira, atuando em áreas onde o hipoclorito não consegue chegar. Não deixando permanecer resíduos de material orgânico, que servem de substrato bacteriano.

MARION et $a l^{56}$ (1991), estudaram por microscopia eletrônica de varredura a morfologia dos odontoblastos e o diâmetro dos túbulos dentinários ao redor da polpa em um premolar de um indivíduo de 43 anos. Foi observado que os odontoblastos diminuíam de tamanho na direção cérvico-apical assim 
como os túbulos dentinários. O diâmetro médio dos túbulos dentinários nos três terços foi de: terço cervical e médio - 1,5 a $2 \mu \mathrm{m}$, terço apical - menor que $1 \mu \mathrm{m}$. WAKABAYASHI et $a l^{11}$ (1995), pesquisaram os efeitos da pasta de hidróxido de cálcio sobre as paredes do canal radicular não instrumentada. Foram utilizados 50 dentes unirradiculados seccionados ao meio e a polpa removida com pinças, as metades foram lavadas com água destilada em ultrasom por 10 min e as raízes divididas em 3 grupos:

$\checkmark$ Grupo 1 - A raízes foram cobertas por hidróxido de cálcio $(1 \mathrm{~g} / 1 \mathrm{ml}$ solução salina) por 1 semana;

$\checkmark$ Grupo 2 - A raízes foram cobertas por hidróxido de cálcio $(1 \mathrm{~g} / 1 \mathrm{ml}$ solução salina) por 4 semanas;

$\checkmark$ Grupo 3 - (controle) as raízes não receberam tratamento.

Os espécimes foram preparados para análise por microscopia eletrônica de varredura. As imagens mostraram que no grupo 3, em muitas áreas foi possível observar a presença de células odontoblásticas, fragmentos de polpa, áreas de pré-dentina exposta e também áreas de tecido fibroso. No grupo 1, foi observada uma faixa de pré-dentina exposta com muitas aberturas nos túbulos dentinários, nas quais se podia ver os processos odontoblásticos. Células e fibras não foram encontradas, apenas debris. No grupo 2, minúsculos debris sobre a pré-dentina foram encontrados, as aberturas dos túbulos dentinários tinham aproximadamente de 5 a $10 \mu \mathrm{m}$ contra $2 \mu \mathrm{m}$ do grupo 1. Não foi possível 
visualizar os processos odontoblásticos e, a pré-dentina apresentou pequenas áreas de erosão.

WADACHI et al $l^{89}$ (1998), pesquisaram os efeitos do hidróxido de cálcio na dissolução de matéria orgânica, no tecido pulpar remanescente, nas paredes dentinárias do canal radicular. Foram utilizados para o experimento blocos de $2 \mathrm{~mm}$ da porção média da raiz de dentes bovinos, que receberam aplicação de hidróxido de cálcio (em veículo aquoso e viscoso) e hipoclorito de sódio. Os resultados mostraram que o hidróxido de cálcio tem sua maior capacidade de dissolução de matéria orgânica, em aproximadamente sete dias, enquanto o hipoclorito leva aproximadamente 60 segundos. Porém o hidróxido de cálcio pode potencializar a ação do hipoclorito de sódio, dissolvendo a matéria orgânica residual, que escapou ao preparo do canal, ou que não sofreu ação do hipoclorito de sódio devido a variações anatômicas.

\subsection{Comportamento biológico do hidróxido de cálcio.}

O comportamento biológico do hidróxido de cálcio também foi estudado por diversos autores:

HAMMARSTRÖM et $a l^{39}$ (1986), observaram os efeitos do curativo de hidróxido de cálcio no reparo periapical e na reabsorção radicular. Foram utilizados nesse estudo incisivos laterais de 10 macacos. Dois dentes de um dos 
lados de cada animal foram abertos. Todos os dentes foram extraídos, simuladas reabsorções apicais com brocas e os dentes imediatamente reimplantados. Dez dias após o reimplante, a pasta Calasept foi colocada em alguns dentes e outros deixados abertos. Nos períodos de 6, 24h e 3 dias após o tratamento os dentes foram extraídos e preparados para Microscopia eletrônica de varredura. Nos períodos de 24h, 1, 4 e 8 semanas um animal foi sacrificado e feito análise por microscopia. O reparo do ligamento periodontal foi afetado pela presença de infecção e, os dentes sem infecção tiveram reparo normal. O hidróxido de cálcio necrosou as células em contato com a dentina externa, podendo favorecer a anquilose, também induziu formação óssea e preveniu a reabsorção inflamatória.

HOLLAND et $a t^{43}$ (1998), compararam em dentes de cães, a associação de hidróxido de cálcio e corticosteróide-antibiótico, como curativos intracanal em casos de biopulpectomia. Os dentes foram sobre instrumentados e medicados com corticosteróide-antibiótico ou pasta de hidróxido de cálcio por 7 dias, antes da obturação, que foi realizada com cimentos Sealapex e óxido de zinco e eugenol (OZE). Os animais foram sacrificados 180 dias após o tratamento e os espécimes preparados para análise morfológica. Os casos obturados com Sealapex mostraram um maior número de casos com selamento biológico apical (aproximadamente 80\% dos casos), independente do curativo. Quando os canais foram obturados com OZE o preenchimento prévio com pasta de hidróxido de 
cálcio proporcionou melhores resultados, porém os resultados foram bem inferiores ao uso do Sealapex.

GUIGAND et $a l^{34}$ (1999), avaliaram a citocompatibilidade de três materiais de uso em Endodontia, o hidróxido de cálcio, óxido de cálcio e um cimento a base de óxido de zinco e eugenol. Foram realizadas análises em cultura de células (teste de citotoxicidade por clorimetria e citometria de escoamento) e microscopia eletrônica de varredura, nos períodos de 24, 72 e 168h. Os resultados confirmaram a inicial citotoxicidade do cimento à base de óxido de zinco e eugenol e mostrou que o composto à base de óxido de cálcio, teve o mesmo comportamento satisfatório de citocompatibilidade que o hidróxido de cálcio.

HOLLAND et $a l^{44}$ (1999), avaliaram as reações do tecido conjuntivo de ratos ao implante de tubos de dentina, preenchidos com agregado trióxido mineral e hidróxido de cálcio. Tubos de dentina de $7 \mathrm{~mm}$ de comprimento alargados até o instrumento número 35 foram lavados com EDTA e hipoclorito de sódio e com água destilada após autoclavagem. Os canais foram preenchidos com os materiais citados acima e implantados na região subcutânea dorsal de ratos. Os animais foram sacrificados aos 7 e 30 dias de pós-operatório. As peças foram fixadas e preparadas para microscopia por coloração de hematoxicilina eosina. Os dois materiais tiveram resultados similares exibindo alta 
birrefringência a luz polarizada, possivelmente os dois materiais têm a mesma a capacidade de induzir mineralização.

NELSON FILHO et at ${ }^{60}$ (1999), analisaram as respostas dos tecidos conjuntivos de ratos a medicamentos à base de hidróxido de cálcio. Nesse estudo foram utilizados 120 ratos fêmeas, com 68 semanas, pesando entre 12 a 20 gramas, divididos em 5 grupos:

a) grupo 1 - Calen (S. S. White 2,5g de $\mathrm{Ca}(\mathrm{OH})_{2}, 0,5 \mathrm{~g}$ de óxido de zinco, 0,05g de colofônia e $1,75 \mathrm{ml}$ de polietilenoglicol 400)

b) grupo 2 - Calen PMCC (S. S. White 2,5g de $\mathrm{Ca}(\mathrm{OH})_{2}, 0,5 \mathrm{~g}$ de óxido de zinco, $0,05 \mathrm{~g}$ de colofônia, $1,75 \mathrm{ml}$ de polietilenoglicol 400 e $0,15 \mathrm{mg}$ de PMCC - 2,5:7,5)

c) grupo 3 - Calen + PMC $(0,04 \mathrm{~g})$

d) grupo 4 - Calasept - (Scania Dental, Stockholm, Sweden)

e) grupo 5 - Controle - Solução Salina Tamponada (PBS)

Foram injetados: $0,01 \mathrm{ml}$ de cada suspensão no tecido subcutâneo dos ratos e, os períodos de sacrifício dos animais foram de: 6,12 e 24 h e 2, 3, 5, 715 dias. Todas as pastas induziram respostas inflamatórias nos diferentes períodos, com edema, hemorragia, infiltrado inflamatório leucocitário, passando a um aumento das células mononucleadas e formação de granulomas de corpo estranho e necrose da área de inoculação. Segundo os autores os dados não devem ser extrapolados para os tecidos periapicais. 
TROPE et al $l^{87}$ (1999), compararam a reparação radiográfica de dentes com periodontites apicais tratados em única sessão ou duas sessões, com ou sem uso de hidróxido de cálcio. Foram selecionados pacientes que apresentassem lesões periapicais visíveis radiograficamente e os dentes foram divididos em 3 grupos; No primeiro os dentes foram tratados em uma única sessão e não foi utilizado qualquer tipo de curativo intracanal, no grupo 2 os canais foram deixados vazios e obturados 1 semana após, no grupo 3 foi utilizado pasta de hidróxido de cálcio como curativo intracanal na primeira sessão, que foi removido na segunda sessão (1 semana após) e os canais obturados. Os casos foram acompanhados por 52 semanas e estabelecidos escores para avaliar a reparação periapical. O grupo do hidróxido de cálcio proporcionou uma reparação mais rápida e mais efetiva em relação aos demais grupos, com diferença estatisticamente significante.

DSTOMAT et $a l^{17}$ (2000), pesquisaram os efeitos do hidróxido de cálcio e o fator de crescimento tumoral beta (TGF- $\beta$ ), sobre a síntese de colágeno em subculturas I e V de osteoblastos. O TGF- $\beta$ aumentou significantemente a síntese de colágeno em ambas subculturas de odontoblastos. O hidróxido de cálcio não interferiu na síntese de colágeno, tendo resultados semelhantes ao grupo controle, em que nada foi administrado. A associação do TGF- $\beta$ ao hidróxido de cálcio aumentou a síntese de colágeno pelos odontoblastos e talvez 
no futuro possa ter aplicações clínicas. Porém necessita-se de mais estudos in vitro e in vivo.

WEIGER et $a l^{92}$ (2000), estudaram clinicamente a influência do curativo intracanal de hidróxido de cálcio por uma semana, em relação ao tratamento em sessão única, em pacientes portadores de lesões periapicais visíveis radiograficamente. Trinta e seis dentes foram tratados em sessão única e trinta e um em duas sessões com curativo de hidróxido de cálcio. A ausência de sinais e sintomas clínicos e a reparação verificada por meio de radiografias foram os critérios para o sucesso dos tratamentos. O sucesso excedeu os $90 \%$ em ambos os grupos, sendo que para os autores o tratamento em sessão única é uma alternativa para o tratamento de dentes com lesões periapicais.

HOLLAND et $a l^{45}$ (2001), observaram as reações do tecido conjuntivo de ratos ao implante de tubos de dentina preenchidos com agregado trióxido mineral, cimento tipo Portland e hidróxido de cálcio. Tubos de dentina de $7 \mathrm{~mm}$ de comprimento, alargados até o instrumento número 35 , foram lavados com EDTA e hipoclorito de sódio e com água destilada após autoclavagem. Os canais foram preenchidos com os materiais citados acima e implantados na região subcutânea dorsal de ratos. Os animais foram sacrificados após 7 e 30 dias de pós-operatório. As peças foram fixadas e preparadas para microscopia por coloração de hematoxicilina eosina. Os resultados foram bastante similares entre os grupos. Ao sétimo dia pôde-se observar uma moderada inflamação 
crônica e a presença de algumas células gigantes, no trigésimo dia o tecido conjuntivo ao redor das áreas calcificadas estava fibroso e havia algumas células gigantes e ainda uma moderada reação inflamatória crônica.

\subsection{Importância da smear layer.}

A importância da smear layer na terapia endodôntica é traduzida pelo grande número de artigos pesquisados:

FOSTER et $a l^{27}$ (1993), estudaram os efeitos da smear layer sobre a difusão do hidróxido de cálcio na dentina radicular. Foram utilizadas 40 raízes que receberam preparo biomecânico, um defeito externo de $3 \mathrm{~mm}$ de diâmetro por $1 \mathrm{~mm}$ de profundidade, foi criado na superfície externa das raízes. Foram colocadas separadamente em frascos contendo $10 \mathrm{ml}$ de saliva. O pH e o nível de cálcio liberado foram medidos após $24 \mathrm{~h}$. As paredes dentinárias receberam tratamento final de:

- Grupo 1 - 20ml de solução salina;

- Grupo 2 - 10ml de EDTA 17\% seguido de 10ml de hipoclorito de sódio $5,25 \%$

- Grupo 3 - Idem grupo 2 + Colocação de hidróxido de cálcio em veículo aquoso; 
- Grupo 4 - 20ml de hipoclorito de sódio + Colocação de hidróxido de cálcio em veículo aquoso;

$\mathrm{O}$ pH e o nível de cálcio foram marcados a 1, 3, 5 e 7 dias. Os resultados confirmaram que a remoção da smear layer facilita a difusão dos íons cálcio e hidroxila pela dentina.

SEN et $a l^{72}$ (1995), realizaram uma revisão da literatura sobre a smear layer e a caracterizaram como uma massa amorfa, irregular e granular, composta por processos odontoblásticos, restos de tecido dentinário, restos de tecido pulpar, bactérias e material inorgânico. Com partículas de 0,5 a $15 \mu \mathrm{m}$ dependendo do corte dos instrumentos utilizados e do grau de umidade da dentina. A sua penetração nos túbulos dentinários não é muito profunda, porém atrapalha na ação de medicamentos e adesão do cimento à dentina. De acordo com a maioria dos trabalhos a solução mais efetiva para remoção da smear layer é o EDTA, usado alternadamente com o hipoclorito de sódio. O EDTA é capaz de penetrar de 20 a $30 \mu \mathrm{m}$ no interior da dentina, sendo assim capaz de eliminar a smear layer.

YOSHIDA et $a l^{33}$ (1995), pesquisaram clinicamente a ação do EDTA como solução irrigadora final, na recontaminação do canal radicular. Neste estudo foram utilizados 189 dentes, com os canais infectados, de 126 pacientes. Primeiramente os canais foram abertos e coletado material, que foi semeado em 
meio de cultura. O preparo dos canais foi realizado usando hipoclorito de sódio 5\% alternado com $\mathrm{H}_{2} \mathrm{O}_{2} 3 \%$. Os dentes foram divididos em 2 grupos:

$\checkmark$ Grupo 1 - 129 dentes - Aplicação final de EDTA 15\%

$\checkmark$ Grupo 2 - 60 dentes - Aplicação final de Solução Salina.

Todos os dentes foram energizados com ultra-som por 1min e irrigados com água destilada. Outra coleta foi realizada logo após o preparo dos canais, que foram secos com cones de papel e selados temporariamente com cimento de óxido de zinco e eugenol. Após uma semana os dentes foram reabertos e novamente colhido material para análise. Os resultados mostraram que na primeira coleta, antes do preparo dos canais, todas as amostras deram resultado positivo. No grupo 1 (EDTA), na segunda coleta, logo após o preparo, $81 \%$ dos dentes tiveram resultados negativos e na coleta final em $72 \%$ dos dentes não havia contaminação. No grupo 2 (Solução Salina), na segunda coleta, logo após o preparo, $75 \%$ dos dentes tiveram resultados negativos e na coleta final em apenas 35\% dos canais não havia contaminação. Mostrando a efetividade de limpeza do EDTA, atuando mais profundamente na dentina.

BARKHORDAR et al (1997), utilizaram doxiciclina associada à solução salina e hipoclorito de sódio como material para remoção da smear layer, comparada ao EDTA 15\%. Obtiveram excelentes resultados para a doxiciclina, em análise por microscopia eletrônica de varredura. Segundo os autores, 
superior ao EDTA, na limpeza dos túbulos dentinários. Talvez pela adesão aos fibroblastos proporcionada por esse antibiótico.

CALERÓ et al (1997), analisando a quelação dos íons cálcio pelo EDTA por espectrofotometria de absorção atômica, constataram que a velocidade de reação e maior rendimento do EDTA, ocorre no primeiro minuto de aplicação. O maior poder de descalcificação ocorre nos três minutos iniciais. O maior grau de saturação ocorreu no período de 12 horas e a velocidade de reação do EDTA com o cálcio da dentina diminui com o passar do tempo.

KOULAOZIDOU et $a l^{50}$ (1999), estudaram os efeitos citotóxicos em cultura de células, de diferentes concentrações de EDTA (EDTA dissódico e EDTA tetrassódico). Segundo os autores, as maiores concentrações de ambas formulações tiveram o mesmo comportamento, sendo extremamente agressivos.

TAKEDA et $a l^{83}$ (1999), realizaram um estudo comparando a efetividade de três soluções ácidas e dois tipos de lasers na remoção da smear layer. Sessenta premolares humanos foram instrumentados e receberam irrigação final com as seguintes soluções:

$\checkmark$ Grupo 1 - EDTA 17\%, 5min;

$\checkmark$ Grupo 2 - ácido fosfórico 6\%, 5min;

$\checkmark$ Grupo 3 - ácido cítrico 6\%, 5min;

$\checkmark$ Grupo 4 - aplicação do laser de $\mathrm{CO}_{2}$

$\checkmark$ Grupo 5 - aplicação do laser de Er:YAG 
Posteriormente os dentes foram seccionados no sentido longitudinal e, analisados por microscopia eletrônica de varredura. Os resultados mostraram melhores resultados de limpeza com o laser de Er:YAG, seguido do $\mathrm{CO}_{2}$; já os ácidos não foram muito efetivos na remoção da smear layer.

O'CONNELL et at (2000), fizeram um estudo comparativo sobre a remoção da smear layer usando diferentes sais de EDTA, Os canais radiculares de 18 dentes foram instrumentados pelo sistema GT e profile 29, até o instrumento número sete taper .04 e, irrigados com hipoclorito de sódio 5,25\%, alternado com três tipos sal de EDTA: sal alcalino à 15\% (tetrassódico), sal ácido 15\% (dissódico) e sal alcalino 25\% (tetrassódico). O pH das soluções foi ajustado em 7,1 usando hidróxido de sódio e ácido clorídrico. Após as irrigações os dentes foram fraturados no sentido longitudinal e, analisados por microscopia eletrônica de varredura nos terços cervical, médio e apical. Os resultados mostraram que a irrigação alternada de EDTA e hipoclorito de sódio removeu totalmente a smear layer dos terços cervical e médio, porém foi menos efetiva no terço apical. Nenhuma das soluções foi completamente efetiva na remoção da smear layer, em qualquer nível e, o sal tetrassódico apresentou comportamento semelhante ao sal dissódico comumente usado.

TIMPAWAT et $a l^{85}$ (2001), pesquisaram os efeitos da remoção da smear layer na micro-infiltração apical. Trinta dentes foram instrumentados e divididos e 2 grupos: grupo 1 canais irrigados com hipoclorito de sódio 5,25\%, sem 
remoção da smear layer, grupo 2 canais irrigados com EDTA 15\% seguido de hipoclorito de sódio 5,25\% para remoção da smear layer. Todos os canais foram obturados com termoplastificação pelo sistema Obtura II e cimento Ketac Endo. Foram deixados em umidade $100 \%$ à $37^{\circ} \mathrm{C}$ por 2 dias, e a infiltração apical foi medida por condução hidráulica, pela movimentação capilar de um bolha de ar após a aplicação de $200 \mathrm{mmHg}$ sobre o sistema. A média de infiltração no grupo 1 e grupo 2 foi respectivamente 13 e 16,9nl/s.

\subsection{Efeitos diversos e aplicações do hidróxido de cálcio sob a terapia endodôntica.}

Alguns trabalhos esclarecem sobre o efeito do hidróxido de cálcio no selamento apical, bem como a eficiência na colocação e remoção das pastas, além de sugerir outras aplicações:

GORDON et $a l^{32}$ (1986), pesquisaram as variações de $\mathrm{pH}$ em diferentes períodos, de dois cimentos à base de hidróxido de cálcio: Sealapex e CRCS. E, um cimento à base de óxido de zinco e eugenol: Tipo Grossman. Quarenta dentes tiveram seus canais instrumentados e, em seguida obturados, pela técnica da condensação lateral ativa de cones de guta-percha. Os períodos de avaliação foram: 1, 4h, 1 e 3 dias. O Sealapex promoveu os maiores valores de $\mathrm{pH}: 8,34$ no pico de 4 h. O valor de 7,46 para o CRCS e 7,11 para o cimento tipo 
Grossman; com diferença estatisticamente significante entre o Sealapex e os demais grupos.

TAGGER et $a l^{82}$ (1988), observaram que a liberação de íons cálcio e hidroxila, de cimentos endodônticos contendo hidróxido de cálcio, colocados em corpos de prova de $7 \mathrm{~mm}$ de comprimento e $3 \mathrm{~mm}$ de diâmetro, foi insignificante para o cimento CRCS. O Sealapex, que se dissolveu com o passar do tempo, promoveu maiores valores de liberação iônica, parecendo ser a solubilidade a responsável pelo aumento da atividade de dissociação.

Em 1992, SIGURDSSON et $a l^{73}$ Também compararam técnicas de colocação de hidróxido de cálcio em canais radiculares em primeiros molares superiores curvos utilizando:

1. Lentulo - número 25 (Maillefer)

2. Seringa cartige - gauge 21

3. Lima Tipo Kerr número 25

A análise da qualidade do preenchimento foi radiográfica, mostrando para a broca lentulo os melhores escores de preenchimento.

RIVIERA; WILLIANS ${ }^{66}$ (1994), compararam a eficiência de colocação de pastas de hidróxido de cálcio, utilizando água ou glicerina como veículo, em canais simulados em blocos plásticos. As pastas foram levadas aos canais com brocas lentulo número 3. A qualidade do preenchimento foi analisada em radiografias, pela densidade apresentada nos terços cervical, médio e apical. 
Foram estabelecidos escores pelos observadores. A glicerina proporcionou um preenchimento na faixa dos $86 \%$ e a água $61 \%$.

HOLLAND et $a t^{41}$ (1995), verificaram melhor selamento apical de canais, que receberam medicação prévia de hidróxido de cálcio e foram obturados com cimento à base de óxido de zinco e eugenol, pela técnica da condensação lateral de guta-percha. Segundo os autores, é provável que isto tenha ocorrido pela expansão proporcionada no cimento de óxido de zinco pelo contato com o hidróxido de cálcio, ou pela obliteração dos túbulos dentinários pelos resíduos de hidróxido de cálcio, forçados para o interior dos túbulos, diminuindo a permeabilidade entre a obturação e as paredes do canal radicular.

SIQUEIRA; FRAGA ${ }^{75}$ também em 1995, verificaram a influência dos resíduos de medicação de hidróxido de cálcio, sobre a obturação de canais radiculares com cimento à base de hidróxido de cálcio (Sealapex). Utilizando diferentes veículos junto ao hidróxido de cálcio: Soro fisiológico, propilenoglicol e azeite de oliva. Os dentes foram submetidos a testes de infiltração por corante. Os espécimes que receberam medicação tiveram uma pequena melhora no selamento apical. Mostrando ausência de interferência, dos resíduos da medicação, no selamento final da obturação.

ESBERARD et al ${ }^{19}$ em 1996, também pesquisando alterações de $\mathrm{pH}$ proporcionadas por cimentos endodônticos, analisaram o $\mathrm{pH}$ da superfície radicular e de preparos confeccionados na superfície radicular de dentes, nos 
terços apical, médio e cervical. Nos períodos de 3, 7, 14, 21, 28, 45, 60, 90 e 120 dias; comparando os cimentos: Sealer 26, Apexit e CRCS. O pH da superfície radicular não foi alterado em nenhum grupo. Essa não alcalinização pode ser devida ao endurecimento dos cimentos, que diminui sua capacidade de dissociação dos íons cálcio e hidroxila. Entretanto, ocorreu uma pequena alteração no $\mathrm{pH}$ das cavidades nos primeiros 3 dias, provavelmente pela ação dos resíduos do hipoclorito de sódio usado no preparo dos canais.

ÇALISCAN; TÜRKÜN ${ }^{10}$ (1998), investigaram os efeitos da medicação de hidróxido de cálcio no selamento apical, utilizado glicerina ou água como veículo. Foram utilizados dois cimentos obturadores: CRCS, Diaket. Os canais foram obturados pela técnica da condensação lateral de guta-percha e o selamento apical avaliado por tese de infiltração por corante, com tinta nankin. Os menores valores de infiltração foram obtidos para os grupo que receberam medicação de hidróxido de cálcio com ambos os veículos e, foram obturados com cimento Diaket. Porém, a água como veículo foi mais efetiva em reduzir a microinfiltração apical. Entre os demais grupos não houve diferença estatisticamente significante. Em observações feitas por microscopia eletrônica de varredura, os autores verificaram que o hidróxido de cálcio não penetrou no interior dos túbulos dentinários. Os cristais estavam presentes na superfície da smear layer de ambos os grupos que foram medicados com hidróxido de cálcio. 
ÇALT; SERPER ${ }^{11}$ (1999), verificaram os efeitos da medicação de hidróxido de cálcio, na penetração intratubular de cimentos endodônticos. Sessenta dentes foram preparados e divididos em dois grupos: no grupo 1 os canais foram preenchidos com pasta de hidróxido de cálcio, no grupo 2 com pasta TempCanal e ambos incubados por 7 dias. Os canais dos dois grupos foram reabertos e irrigados com hipoclorito de sódio e EDTA, para a remoção do hidróxido de cálcio. Os canais foram obturados com CRCS, AH26 e Ketac Endo pela técnica da condensação lateral ativa de guta-percha e incubados por mais 7 dias. A microscopia eletrônica de varredura revelou que o hidróxido de cálcio não é completamente removido das superfícies do canal radicular, quando o hipoclorito de sódio foi utilizado sozinho. Porém, quando o EDTA foi utilizado seguido de irrigação de hipoclorito de sódio o hidróxido de cálcio foi completamente removido e os cimentos endodônticos penetraram nos túbulos dentinários.

LAMBRIANIDIS et $a l^{51}$ (1999), analisaram a eficiência, de diferentes procedimentos, na remoção de pastas de hidróxido de cálcio do interior de canais radiculares: Calxyl, Pulpodent e $\mathrm{Ca}(\mathrm{OH})_{2}$ + água destilada.Em um primeiro procedimento a remoção foi feita com irrigação de solução salina, lima número 25 e irrigação final com solução salina. Em outro procedimento usou-se hipoclorito de sódio, lima número 25 e irrigação final de hipoclorito de sódio, e por último usou-se hipoclorito de sódio, lima número 25 e irrigação final de 
EDTA tetrassódico. Os dentes foram seccionados e fotografados para processamento das imagens e verificação da quantidade de resíduos de hidróxido de cálcio. Nenhum dos métodos promoveu a completa remoção do hidróxido de cálcio dos canais, a pasta utilizada teve um pequeno efeito nos métodos de remoção, não havendo diferença estatisticamente significante entre os grupos.

DEVEAUX et $a l^{16}$ (2000), testaram cinco métodos de colocação do hidróxido de cálcio no interior de canais radiculares de 50 premolares superiores, preparados mecanicamente $1 \mathrm{~mm}$ aquém do forame apical. A pasta de hidróxido de cálcio composta de: duas partes de $\mathrm{Ca}(\mathrm{OH})_{2}$, uma parte de $\mathrm{BaSO}_{4} \mathrm{e}$ água destilada, e colocada no interior dos canais radiculares com:

b) Grupo 1 - Gutta condensors (Maillefer)

c) Grupo 2 - MecaShaper file (Micromega)

d) Grupo 3 - Lima tipo K acionada por Ultrason

e) Grupo 4 - Lentulo número 2 paste Carrier (Maillefer)

f) Grupo 5 - Plastic número 40 paste carrier (Micromega)

As avaliações foram feitas em radiografias digitais, realizadas nos dois sentidos, analisadas por um programa de computação que determina a densidade da imagem em pixels (Sens-A-Ray image analyser). Os resultados apontaram os melhores resultados para os grupo 4 e 5, sendo de escolha para aplicação de pastas à base de hidróxido de cálcio. 


\section{PROPOSIÇÃO}

Levando em consideração a enorme diversibilidade de aplicação clínic a do hidróxido de cálcio, nos propomos:

- Avaliar, in vitro, as alterações do pH e a liberação de íons cálcio, após a utilização intracanal de pastas de hidróxido de cálcio com diferentes veículos;

- Verificar se existe diferença de comportamento entre dentes humanos e bovinos em relação à premissa anterior;

- Avaliar se o tempo de aplicação do medicamento poderia alterar seu mecanismo de ação. 


\section{MATERIAL E MÉTODOS}

Para realização deste estudo foram utilizados 92 dentes, humanos e bovinos. Foram selecionados 23 premolares superiores humanos apresentando duas raízes e dois canais e 23 premolares inferiores unirradiculados humanos, todos extraídos por motivos ortodônticos e, 46 incisivos laterais inferiores bovinos. Os dentes foram mantidos em solução de formalina $10 \%$ por 24 horas para fixação da matéria orgânica em seguida foram transferidos para solução salina fisiológica estéril. Para facilitar o preparo biomecânico os espécimes tiveram suas coroas removidas próximo a junção amelocementária (Figura 1), mantendo um comprimento de $15 \mathrm{~mm}$ para cada raíz. O comprimento de trabalho foi determinado pela passagem de uma lima tipo Kerr número 10 pelo forame apical, reduzindo-se $1 \mathrm{~mm}$ desse comprimento. Os canais foram sobre instrumentados até o instrumento tipo kerr número 30, até o comprimento da raiz. $\mathrm{O}$ batente apical foi padronizado com o instrumento tipo kerr número 40 para os canais dos premolares superiores e inferiores e instrumento tipo kerr número 80 para os incisivos bovinos. Os canais foram preparados pela técnica escalonada com o auxílio de brocas de Gates Glidden números 1 e 2 nos dentes humanos e, a entrada dos canais regularizada com a ponta diamantada 2082 (KG Sorensen) em alta rotação, para padronização dos espécimes. Durante todo preparo biomecânico os canais foram irrigados com hipoclorito de sódio 2,5\% e, 
a irrigação final realizada com solução de EDTA trissódico por 3min, neutralizada com solução salina fisiológica.

Para neutralizar a alcalinidade do hipoclorito de sódio as raízes foram colocadas em um frasco contendo solução salina fisiológica estéril, trocada a cada 48 horas, por 14 dias.

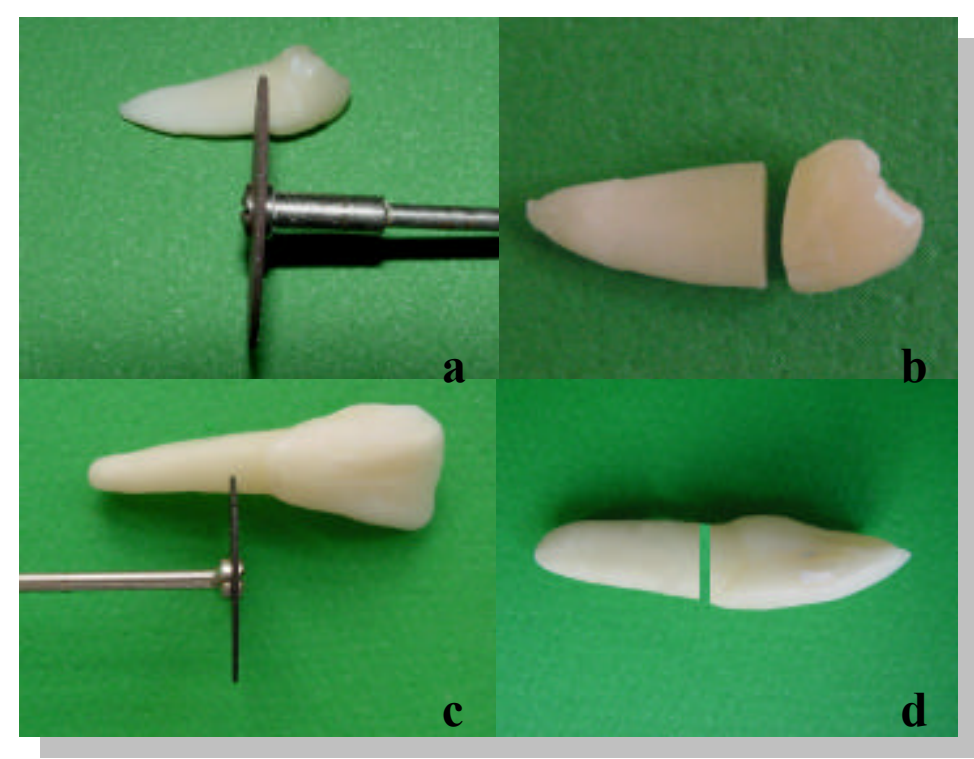

Figura 1 - a) secção da coroa (dente humano);

b) premolar inferior humano seccionado;

c) secção da coroa (dente bovino);

d) incisivo lateral inferior bovino seccionado.

As raízes dos dentes humanos e bovinos foram divididas em 4 subgrupos de maneira que os subgrupos ficassem homogêneos entre si; para tanto foram utilizadas as imagens radiográficas dos dentes para dividi-los de maneira uniforme entre os subgrupos, quanto ao volume do canal radicular. 
Os subgrupos humanos ficaram com 5 premolares superiores, 5 premolares inferiores cada.

Os subgrupos bovinos ficaram com 10 raízes cada.

No terço médio da face vestibular de cada espécime foi realizado um preparo retangular com $4 \mathrm{~mm}$ no sentido longitudinal por $2 \mathrm{~mm}$ no sentido transversal e 1mm de profundidade (Figura 2), realizados com ponta diamantada cilíndrica de $2 \mathrm{~mm}$ de diâmetro n⿳0 2094 (KG Sorensen) em alta-rotação. Para padronização, utilizou-se um microscópio modificado acoplado a um micrômetro de precisão, posicionando a raiz e a turbina de alta rotação (Figura 3).

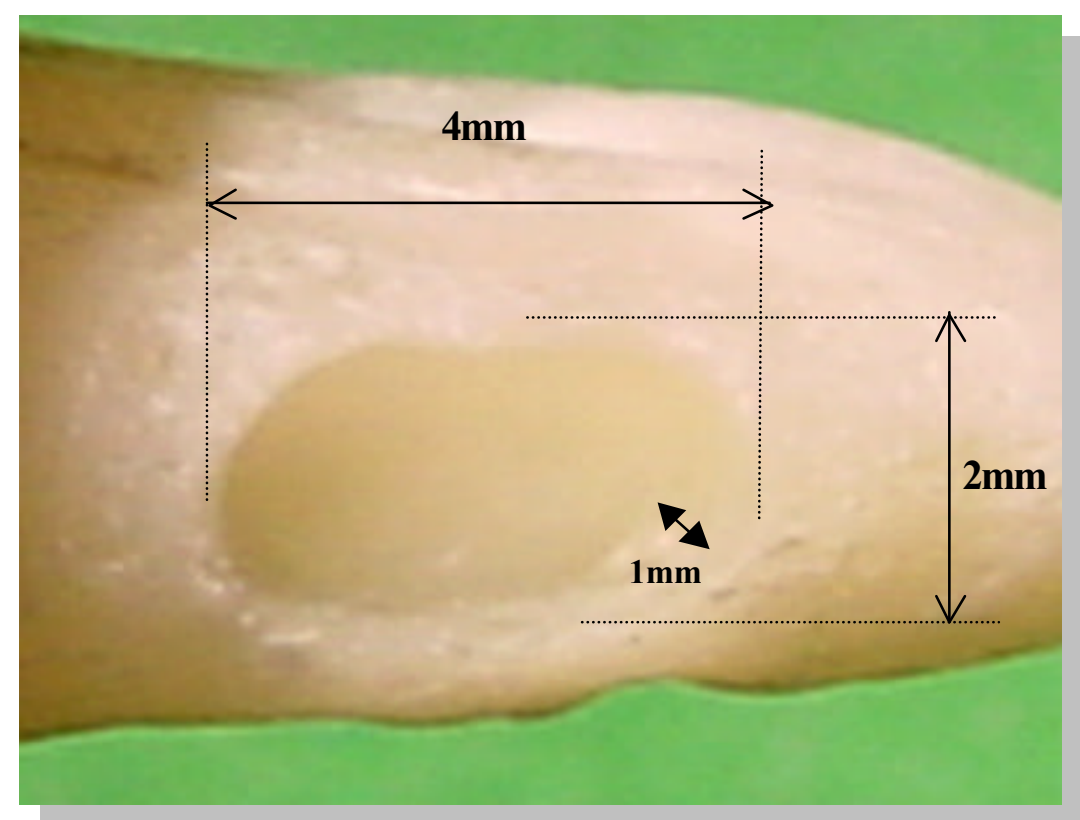

Figura 2 - dimensões do preparo na face vestibular da raiz. 


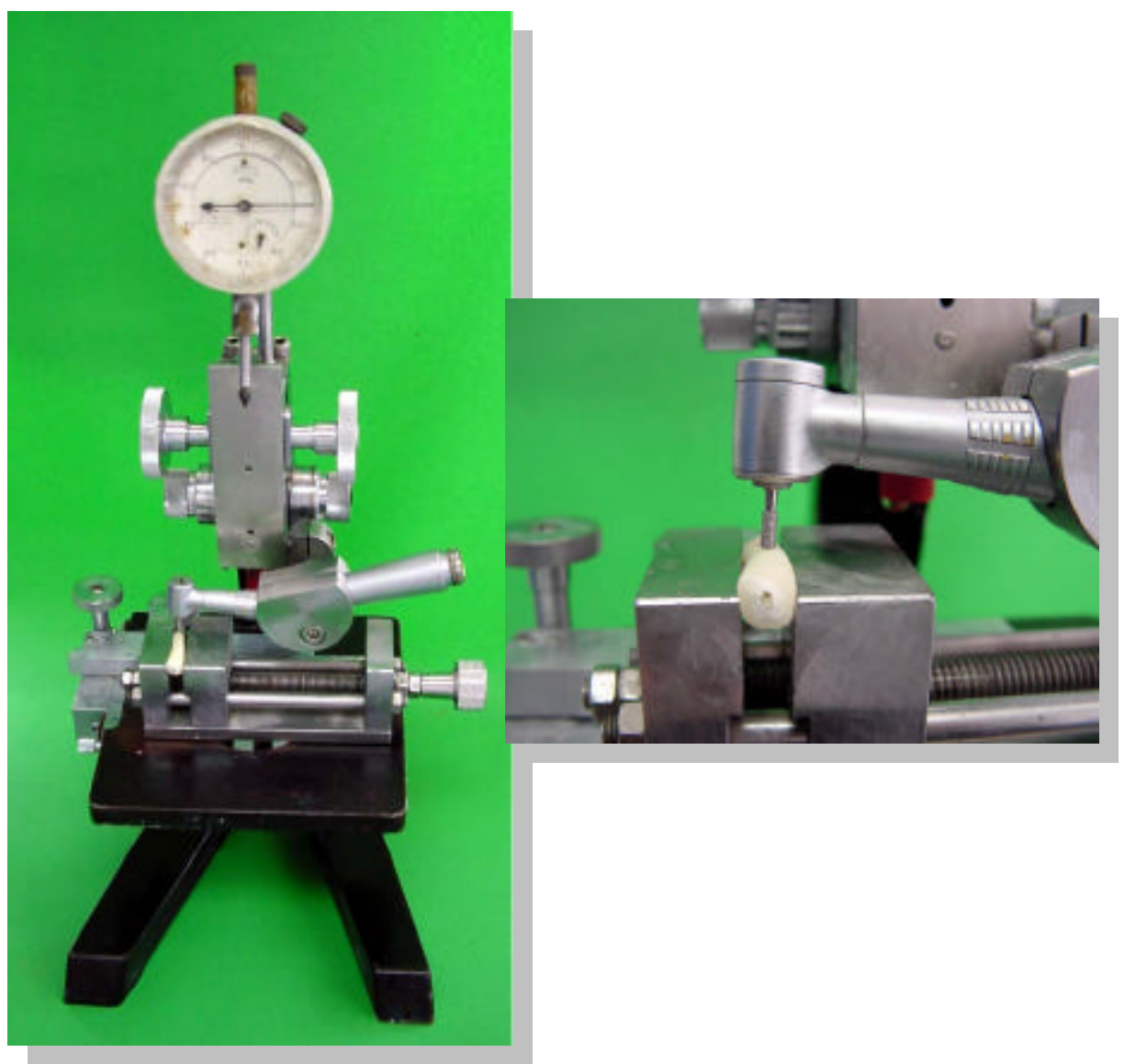

Figura 3 - Microscópio modificado para acoplar a turbina de alta rotação, em conjunto a um micrometro de precisão.

Após o preparo os canais foram preenchidos com pastas à base de hidróxido de cálcio e, as raízes foram divididas em subgrupos de acordo com o veículo da pasta de hidróxido de cálcio:

Subgrupo 1 (D) - Foi utilizada pasta de hidróxido de cálcio p.a (Terapêutica Farmácia de manipulação - São José dos Campos SP) associado ao veículo aquoso (Detergente aniônico - Lauril Sulfato de Sódio veiculado em Metil Parabeno -Tergestesin - Degussa - Catanduva SP) na proporção, 1g para 1ml. 
Subgrupo 2 (S) - Foi utilizada pasta de hidróxido de cálcio p.a. (Terapêutica Farmácia de manipulação - São José dos Campos SP) em veículo aquoso (solução salina fisiológica estéril) na proporção $1 \mathrm{~g}$ para $1 \mathrm{ml}$.

Subgrupo 3 (C) - Foi utilizada pasta de hidróxido de cálcio associado ao paramonoclorofenol Canforado PMCC (paramonoclorofenol PMC - 25\% para 75\% de cânfora) em veículo viscoso Polietilenoglicol 400 (Calen PMCC SSWhite - Rio de Janeiro RJ).

Subgrupo 4 (F) - Foi utilizada pasta de hidróxido de cálcio associado a paramonoclorofenol Furacinado PMCF (5g de paramonoclorofenol para 28ml de Furacin Oto-Solução) em veículo viscoso Polietilenoglicol 400, na proporção $1 \mathrm{~g}$ de hidróxido de cálcio para 0,36ml de PMCF e 0,64ml de polietilenoglicol 400. (Terapêutica - Farmácia de manipulação - São José dos Campos, SP).

Dois premolares inferiores humanos e dois incisivos laterais inferiores bovinos foram usados como controle positivo 1, sendo preenchidos com hidróxido de cálcio em solução salina e não receberam impermeabilização, outros dois premolares inferiores humanos e dois incisivos laterais inferiores bovinos foram usados como controle positivo 2, não sendo preenchidos com hidróxido de cálcio e receberam impermeabilização, exceto na área de preparo cavitário e, outros dois premolares inferiores humanos e dois incisivos laterais iferiores bovinos foram utilizados como controles negativos, recebendo medicação de hidróxido de cálcio em solução salina e em seguida foram 
totalmente impermeabilizados. A divisão dos dentes foi ilustrada no esquema, Um tubo foi preenchido com $4 \mathrm{ml}$ de solução salina fisiológica estéril e usado como controle.

ESQUEMA 1:

Esquema 1 - Divisão dos grupos de dentes humanos e bovinos entre os subgrupos e os períodos de avaliação utilizados

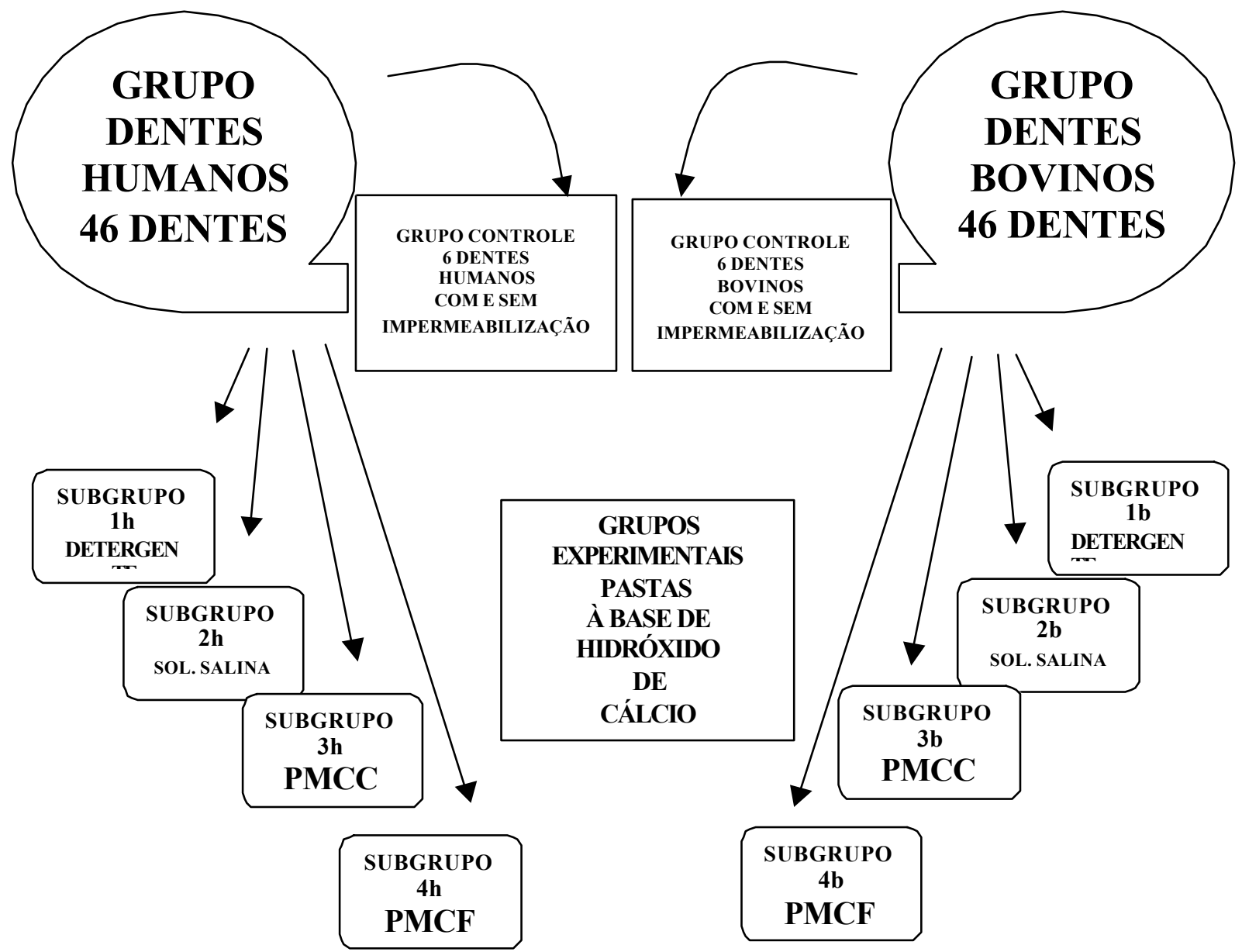

AVALIAÇÀO DO pH E LIBERAÇÃO DE ÍONS CÁLCIO AOS 7 E 14 DIAS 
As pastas de hidróxido de cálcio foram espatuladas e, levadas ao interior dos canais radiculares por meio de brocas "lentulo" (Maillefer - Suíça) até o extravasamento apical das mesmas (Figura 3a). A abertura coronária e a superfície externa das raízes foram impermeabilizadas com uma camada de esmalte de unhas (Figura 3b) e uma camada de cera pegajosa (Figura 3c), exceto na área de preparo. Cada espécime foi imerso em $4 \mathrm{ml}$ de solução salina fisiológica estéril em frascos plásticos individuais, previamente lavados em ácido clorídrico a $25 \%$ e enxaguados em água deionizada e, mantidos a $37^{\circ} \mathrm{C}$.

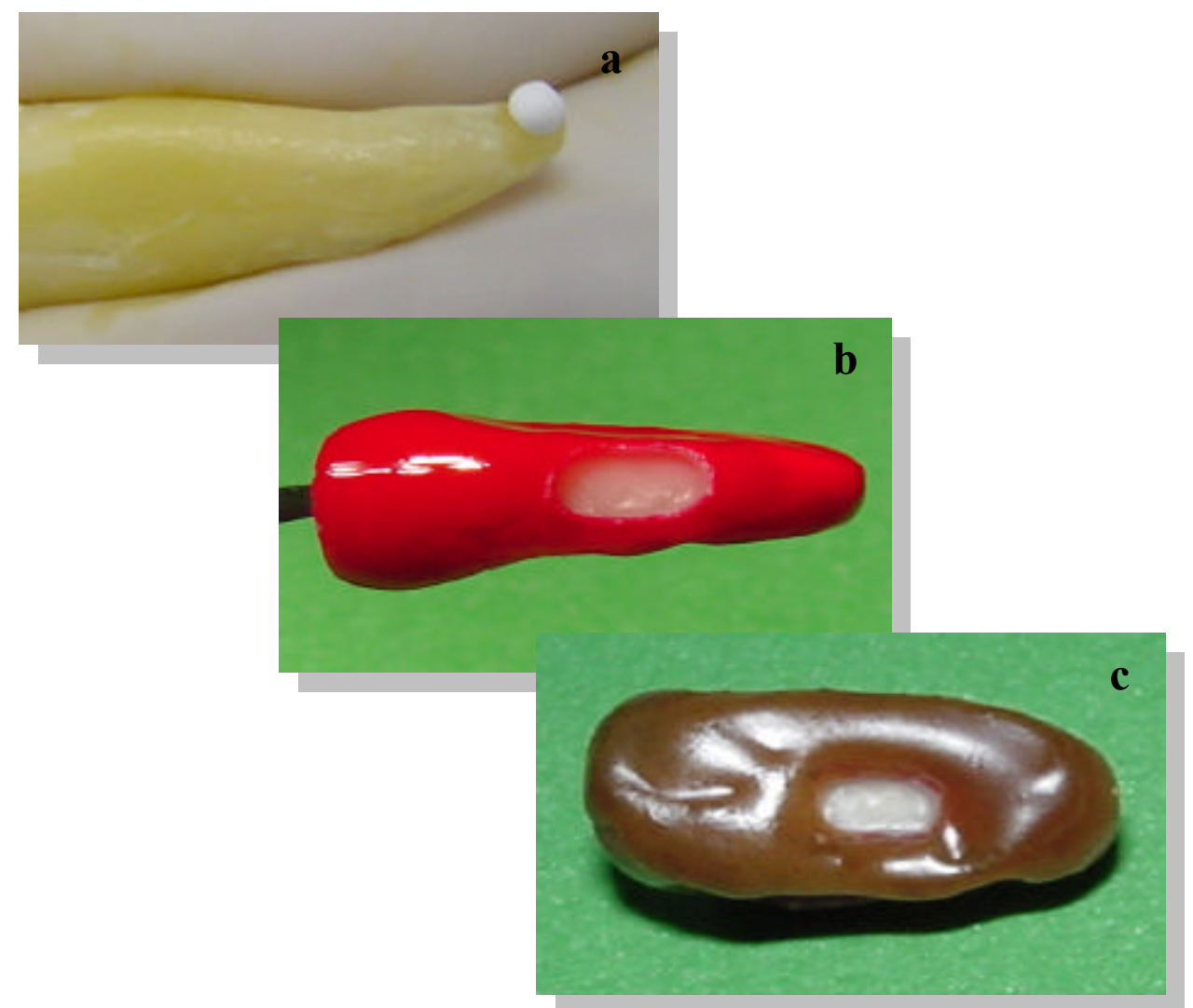

Figura 4 - a) extravasamento da pasta de $\mathrm{Ca}(\mathrm{OH})_{2}$ após a colocação

b) impermeabilização com esmalte de unhas;

c) impermeabilização com cera pegajosa. 
A mensuração do $\mathrm{pH}$ foi realizada com um pHmetro de precisão (Hanna modelo HI 9224) frascos (Figura 5a), acoplado a um eletrodo convencional (Mettler Toledo), que possui a sua membrana de aferição da solução no vértice do eletrodo (seta) (Figura 5b). Permitindo a colocação de um pequeno volume de solução nos frascos, o pHmetro foi devidamente calibrado e colocado na solução salina fisiológica, a qual cada espécime estava imerso, nos períodos de 7 e 14dias.

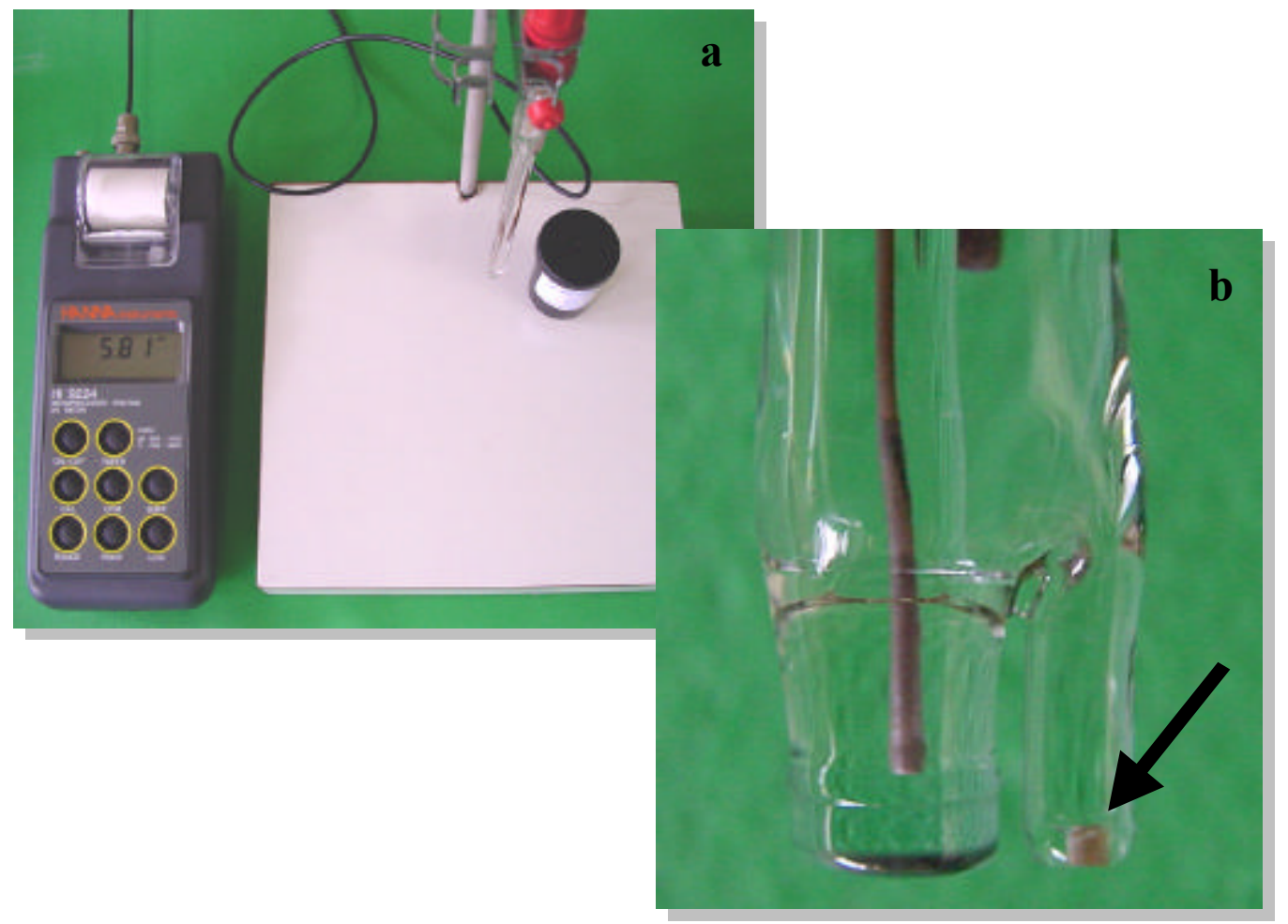

Figura 5 - a) conjunto: pHmetro e eletrodo;

b) ponta do eletrodo, evidenciando a posição da membrana (seta).

Após a mensuração do pH, 0,040ml da solução salina foram removidos de cada frasco e colocados em tubos de ensaio contendo $2 \mathrm{ml}$ de solução 
evidenciadora de cálcio liquiform (Figura 5 c) (Labtest Diagnóstica - São Paulo SP) (Figura 6a), ocorrendo à alteração de cor da solução de evidenciação da presença de íons cálcio (Figura 6d), fazendo análise duplicada para cada espécime, em seguida as soluções foram transferidas para uma cubeta específica para leitura no espectrofotômetro (Figura 6 e; f). Para análise em espectrofotometria UV para íons cálcio foi utilizado um comprimento de onda de 570nm, com um Espectrofotômetro (Shimatzu 1203) (Figura 6b).

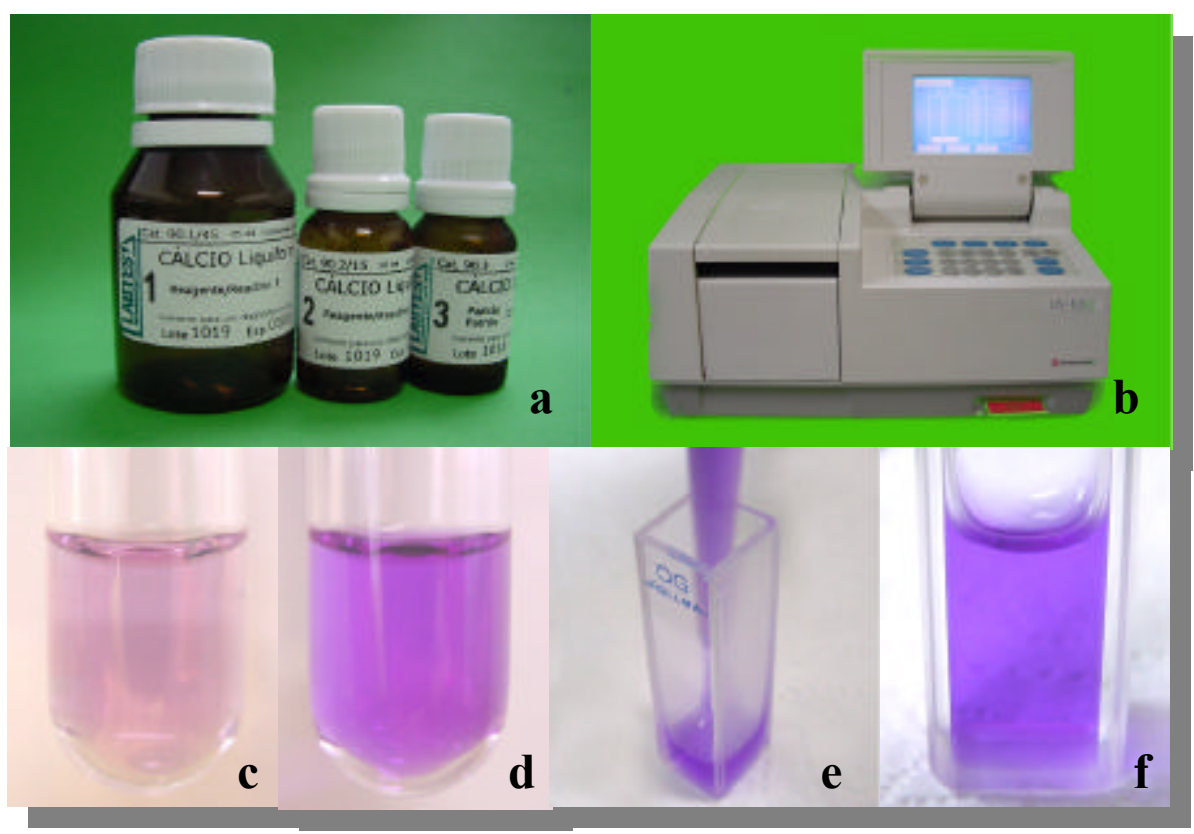

Figura 6 a) Kit de cálcio Liquiform;

b) Espectrofotômetro UV;

c) Solução de cálcio liquiform;

d) Solução misturada à solução salina dos espécimes;

e) Solução sendo pipetada na cubeta;

f) Solução pronta para ser lida no espectrofotômetro. 
Os dados obtidos para a espectrofotometria foram estabelecidos em absorbância e para serem transformados em miligramas de cálcio por decilitros de solução salina, foi necessário fazer uma conversão baseada nos dados de uma solução padrão $(\mathrm{Fc})$.
$\frac{\text { Concentração da Amostra (x) }}{\text { Concentração do Padrão }}=\frac{\text { Absorbância da Amostra }}{\text { Absorbância do Padrão }}$ $10 \mathrm{mg} / \mathrm{dl} \mathrm{de} \mathrm{Ca}^{++}$

\begin{abstract}
Absorbância da Amostra = Valor medido - Absorbância do Padrão
$X=\underline{10 x \text { Absorbância da Amostra }}$

Absorbância do Padrão

$\mathrm{Fc}=\frac{10}{\text { Absorbância do Padrão }}$

$\mathrm{X}=$ Fc x Absorbância da amostra
\end{abstract}

Os dados de pH e liberação de cálcio obtidos foram registrados, analisados e submetidos à análise estatística (ANOVA 2) eao teste de Tukey ao nível de significância de 5\%. 


\section{RESULTADOS}

Os resultados de alteração de pH para os espécimes humanos e bovinos estão expressos nas Tabelas 1 e 2 e, os resultados da liberação de íons cálcio estão expressos na tabelas 3 e 4.

Tabela 1 - Valores de $\mathrm{pH}$ para as raízes de dentes humanos para os subgrupos 1(D), 2(S), 3(C) e 4(F) aos 7 e 14 dias

\begin{tabular}{|c|c|c|c|c|c|c|c|c|}
\hline \multirow{2}{*}{ Espécime } & \multicolumn{2}{|c|}{ 1(D) } & \multicolumn{2}{|c|}{ 2(S) } & \multicolumn{2}{|c|}{$3(C)$} & \multicolumn{2}{|c|}{$4(F)$} \\
\hline & 7 dias & 14 dias & 7 dias & 14 dias & 7 dias & 14 dias & 7 dias & 14 dias \\
\hline 1 & 6,90 & 8,20 & 9,57 & 8,32 & 9,55 & 8,31 & 8,01 & 7,63 \\
\hline 2 & 6,25 & 6,80 & 7,49 & 7,88 & 7,73 & 7,93 & 9,70 & 9,35 \\
\hline 3 & 6,52 & 6,60 & 9,08 & 8,41 & 7,72 & 8,08 & 8,99 & 8,47 \\
\hline 4 & 7,71 & 8,21 & 7,05 & 7,58 & 8,32 & 9,11 & 8,08 & 8,10 \\
\hline 5 & 7,90 & 8,02 & 6,62 & 7,36 & 9,27 & 9,61 & 8,60 & 8,85 \\
\hline 6 & 7,62 & 7,97 & 8,12 & 8,54 & 10,10 & 10,79 & 8,24 & 8,51 \\
\hline 7 & 7,16 & 8,92 & 7,05 & 7,30 & 8,10 & 8,89 & 8,51 & 8,23 \\
\hline 8 & 6,81 & 7,27 & 7,22 & 7,73 & 7,81 & 8,36 & 7,53 & 7,27 \\
\hline 9 & 7,65 & 8,68 & 7,93 & 8,46 & 8,23 & 8,67 & 7,65 & 7,06 \\
\hline 10 & 7,18 & 7,95 & 7,12 & 7,88 & 8,45 & 9,13 & 7,82 & 7,11 \\
\hline MÉDIA & 7,17 & 7,86 & 7,72 & 7,94 & 8,53 & 8,89 & 8,31 & 8,05 \\
\hline
\end{tabular}


Tabela 2 - Valores de $\mathrm{pH}$ para as raízes de dentes bovinos para os subgrupos 1(D), 2(S), 3(C) e 4(F) aos 7 e 14 dias

\begin{tabular}{|c|c|c|c|c|c|c|c|c|}
\hline \multirow{2}{*}{\multicolumn{3}{|c|}{$\begin{array}{c}1(\mathrm{D}) \\
\text { Espécime }_{7 \text { dias } 14 \text { dias }}\end{array}$}} & \multicolumn{2}{|c|}{$2(S)$} & \multicolumn{2}{|c|}{$3(C)$} & \multicolumn{2}{|c|}{$4(F)$} \\
\hline & & & 7 dias & 14 dias & 7 dias & 14 dias & 7 dias & 14 dias \\
\hline 1 & 7,45 & 7.80 & 7,71 & 7,87 & 9,02 & 9,34 & 8,47 & 7,49 \\
\hline 2 & 7,55 & 8,92 & 7,15 & 8,56 & 7,98 & 9,16 & 8,55 & 7,60 \\
\hline 3 & 7,05 & 7,86 & 7,75 & 8,21 & 9,06 & 8,57 & 8,38 & 8,36 \\
\hline 4 & 6,98 & 8,01 & 7,78 & 9,03 & 8,54 & 8,18 & 9,21 & 8,94 \\
\hline 5 & 6,87 & 7,98 & 7,00 & 8,49 & 7,59 & 8,81 & 8,13 & 8,02 \\
\hline 6 & 6,87 & 7,77 & 6,82 & 7,76 & 10,01 & 10,34 & 8,21 & 7,92 \\
\hline 7 & 7,59 & 8,37 & 7,23 & 8,56 & 7,58 & 9,01 & 7,57 & 7,98 \\
\hline 8 & 6,81 & 7,42 & 7,01 & 7,81 & 8,06 & 8,59 & 7,38 & 8,36 \\
\hline 9 & 6,97 & 7,82 & 7,87 & 9,35 & 7,94 & 8,68 & 9,27 & 8,96 \\
\hline 10 & 7,16 & 8,14 & 7,12 & 8,63 & 7,09 & 8,31 & 7,62 & 7,95 \\
\hline MÉDIA & 7,13 & 8,00 & 7,34 & 8,43 & 8,28 & 8,90 & 8,27 & 8,15 \\
\hline
\end{tabular}


Tabela 3 - Valores de miligramas de cálcio por decilitro para os subgrupos de raízes de dentes humanos 1(D), 2(S), 3(C) e 4(F) aos 7 e 14 dias

\begin{tabular}{|c|c|c|c|c|c|c|c|c|}
\hline & & (D) & & (S) & & C) & $4(1$ & F) \\
\hline Espécime & 7 dias & 14 dias & 7 dias & 14 dias & 7 dias & 14 dias & 7 dias & 14 dias \\
\hline 1 & 5,05 & 8,98 & 7,10 & 13,11 & 10,69 & 16,72 & 3,09 & 6,41 \\
\hline 2 & 7,32 & 8,11 & 5,89 & 9,31 & 7,88 & 12,14 & 11,51 & 12,25 \\
\hline 3 & 4,25 & 8,33 & 8,16 & 12,57 & 8,76 & 11,47 & 7,36 & 11,82 \\
\hline 4 & 4,76 & 12,13 & 5,62 & 9,27 & 12,56 & 16,72 & 7,96 & 12,94 \\
\hline 5 & 7,76 & 11,24 & 3,70 & 10,91 & 10,10 & 15,99 & 7,96 & 8,92 \\
\hline 6 & 5,77 & 9,49 & 7,17 & 10,82 & 11,06 & 15,38 & 7,01 & 12,25 \\
\hline 7 & 5,09 & 11,39 & 4,69 & 7,77 & 11,99 & 13,33 & 7,94 & 10,64 \\
\hline 8 & 4,38 & 9,68 & 8,21 & 12,18 & 10,38 & 15,47 & 8,13 & 9,36 \\
\hline 9 & 9,29 & 12,02 & 9,23 & 11,76 & 9,25 & 11,22 & 9,28 & 11,31 \\
\hline 10 & 9,69 & 11,91 & 9,21 & 12,08 & 10,31 & 15,65 & 8,31 & 11,78 \\
\hline MÉDIA & 6,33 & 10,32 & 6,90 & 10,97 & 10,29 & 14,40 & 7,85 & 10,77 \\
\hline
\end{tabular}


Tabela 4 - Valores de miligramas de cálcio por decilitro para os subgrupos de raízes de dentes bovinos 1(D), 2(S), 3(C) e 4(F) aos 7 e 14 dias.

\begin{tabular}{|c|c|c|c|c|c|c|c|c|}
\hline & & (D) & & S) & & C) & & (F) \\
\hline Espécime & 7 dias & 14 dias & 7 dias & 14 dias & 7 dias & 14 dias & 7 dias & 14 dias \\
\hline 1 & 4,35 & 9,08 & 8,41 & 12,01 & 12,38 & 14,47 & 8,10 & 9,60 \\
\hline 2 & 7,09 & 11,59 & 9,62 & 16,06 & 12,52 & 15,01 & 10,28 & 12,35 \\
\hline 3 & 9,38 & 11,51 & 9,21 & 16,18 & 14,91 & 17,55 & 12,31 & 15,86 \\
\hline 4 & 9,59 & 16,32 & 10,83 & 15,01 & 9,01 & 16,47 & 12,37 & 15,58 \\
\hline 5 & 6,61 & 10,92 & 2,67 & 15,73 & 9,93 & 15,37 & 10,25 & 13,21 \\
\hline 6 & 4,65 & 8,19 & 7,10 & 13,21 & 10,69 & 16,72 & 3,09 & 6,41 \\
\hline 7 & 7,23 & 8,01 & 7,77 & 11,33 & 10,88 & 12,14 & 11,51 & 12,25 \\
\hline 8 & 6,23 & 9,33 & 9,16 & 12,57 & 8,76 & 11,47 & 8,36 & 11,82 \\
\hline 9 & 7,75 & 10,33 & 7,62 & 9,62 & 12,56 & 16,72 & 10,66 & 12,94 \\
\hline 10 & 4,62 & 11,24 & 8,71 & 10,92 & 10,10 & 15,99 & 9,96 & 11,92 \\
\hline MÉDIA & 6,75 & 10,65 & 8,11 & 13,26 & 11,17 & 15,19 & 9,68 & 12,19 \\
\hline
\end{tabular}


Os valores de $\mathrm{pH}$ dos controles foram os seguintes:

Controle positivo 1; sem impermeabilização, com pasta no interior dos canais radiculares:

- Dente bovino, 7 dias - 11,26; 14 dias - 10,25;

- Dente humano, 7 dias - 11,55; 14 dias - 9,42;

Controle positivo 2; impermeabilização total exceto na área do preparo, sem pasta no interior dos canais radiculares:

- Dente bovino, 7 dias -6,70; 14 dias - 6,82;

- Dente humano, 7 dias $-6,63 ; 14$ dias $-6,79$

Controle negativo; impermeabilização total, com pasta no interior dos canais radiculares:

- Dente bovino, 7 dias - 6,10; 14 dias - 7,02;

- Dente humano, 7 dias - 6,15; 14 dias - 7,03;

Controle da Solução Salina Fisiológica estéril

- $\quad 7$ dias $-7,14 ; 14$ dias $-7,02$ 
Os valores de liberação de cálcio em mg/dl dos grupos controle foram os seguintes:

Controle positivo 1; sem impermeabilização, com pasta no interior dos canais radiculares:

- Dente bovino, 7 dias - 20,37; 14 dias - 20,39;

- Dente humano, 7 dias - 20,22; 14 dias - 20,37

Controle positivo 2; impermeabilização total exceto na área do preparo, sem pasta no interior dos canais radiculares:

- Dente bovino, 7 dias -1,0; 14 dias - 1,2;

- Dente humano, 7 dias - 0,08; 14 dias - 0,12

Controle negativo; impermeabilização total, com pasta no interior dos canais radiculares:

- Dente bovino, 7 dias - 0,07; 14 dias - 0,10;

- Dente humano, 7 dias - 0,05; 14 dias - 0,08; 
Foram amostrados um conjunto de 184 dados, subdivididos em 8 subgrupos, e dois grupos de dentes (humanos e bovinos). Estes subgrupos foram avaliados a 7 e 14 dias. Conforme o teorema do limite central, existe uma exigência estatística de que o conjunto total amostrado deve ser superior a 30 dados, para a hipótese de normalidade e continuidade entre os dados seja utilizada.

Neste caso, pode-se utilizar como método de comparação de variabilidade entre os grupos o teste ANOVA - Análise de Variância. Foi adotado como nível de significância o valor de 5\% para a rejeição sobre a hipótese de desigualdade entre os grupos. Isto equivale a afirmar que quando o p-nível (probabilidade de igualdade entre grupos) for menor que 5\% pode-se rejeitar a hipótese básica de igualdade. A probabilidade de erro nas afirmações concluídas pela inferência foi de $5 \%$ também, o que garantia uma confiança de $95 \%$ na conclusão final.

Nas páginas seguintes seguem as análises de pH e liberação de cálcio. Nas Figuras $7,8,9,10,11$ e 12 pode-se verificar o padrão de alteração do pH e liberação de cálcio dos dentes humanos e bovinos, nos dois períodos: 7 e 14 dias. A figuras 9 e 12 mostram as interações tempo $\mathrm{X}$ pasta $\mathrm{X}$ pH ou liberação de cálcio. As Tabelas 5 e 6 representam os testes ANOVA e os quadros 2, 3, 4 e 5 representam os testes de TuKey. 


\section{Análise Estatística dos Dados de pH:}

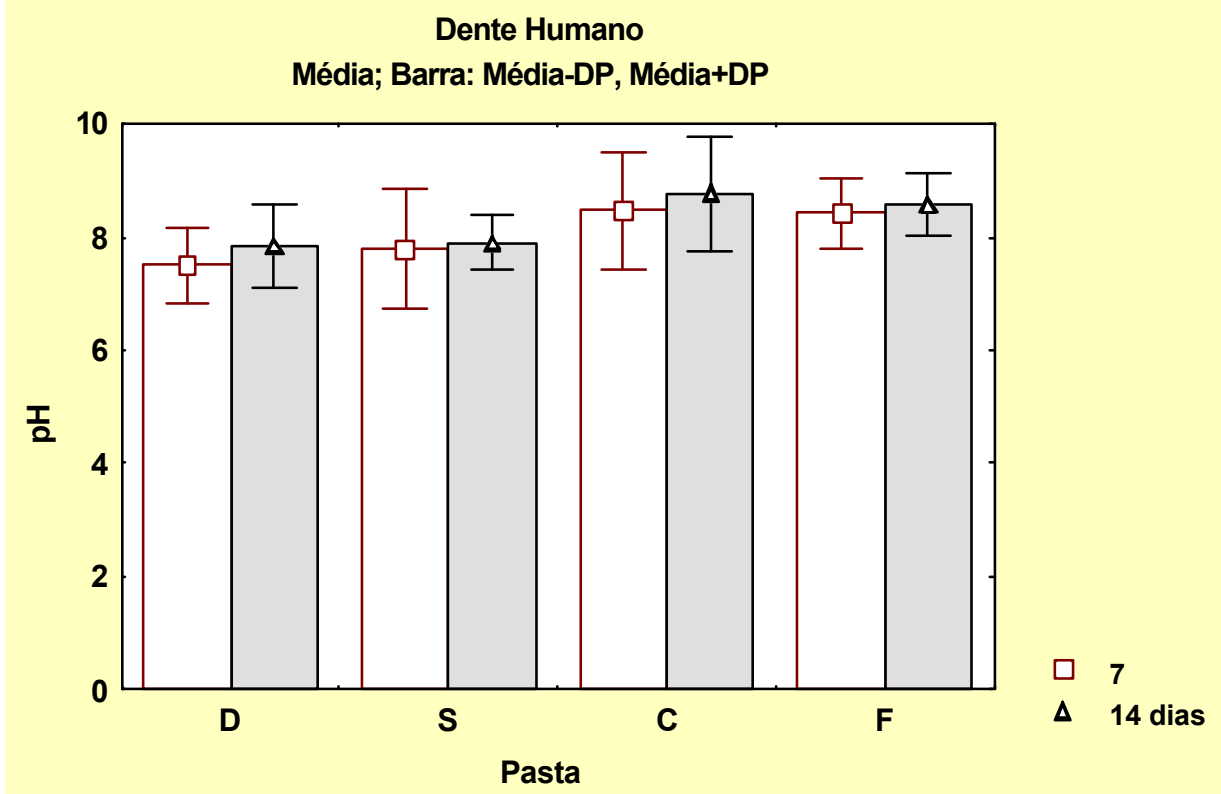

Figura 7 - Valores médios de $\mathrm{pH}$ aos 7 e 14 dias para os dentes humanos; subgrupo 1 - D, subgrupo $2-\mathrm{S}$, subgrupo 3 - C e subgrupo $4-\mathrm{F}$.

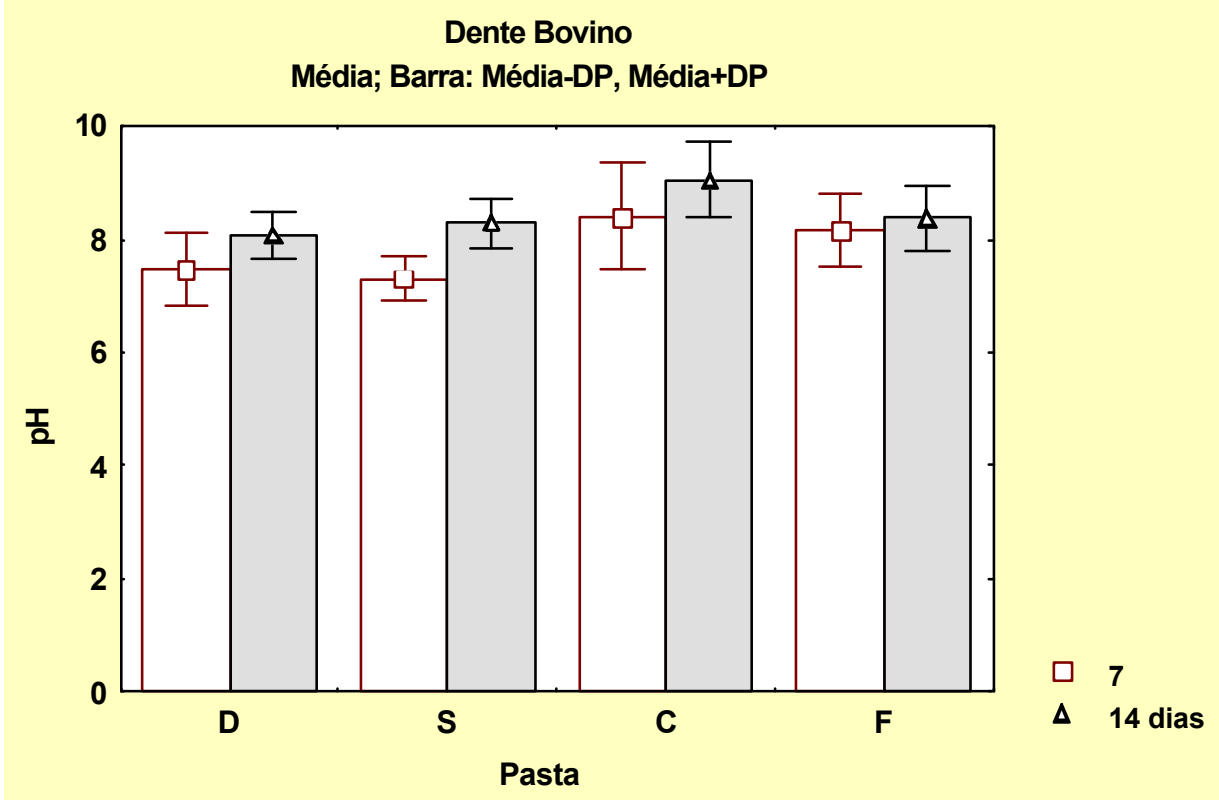

Figura 8 - Valores médios de pH 7 e 14 dias para os dentes bovinos; subgrupo $1-D$, subgrupo $2-S$, subgrupo 3 - C e subgrupo $4-F$. 


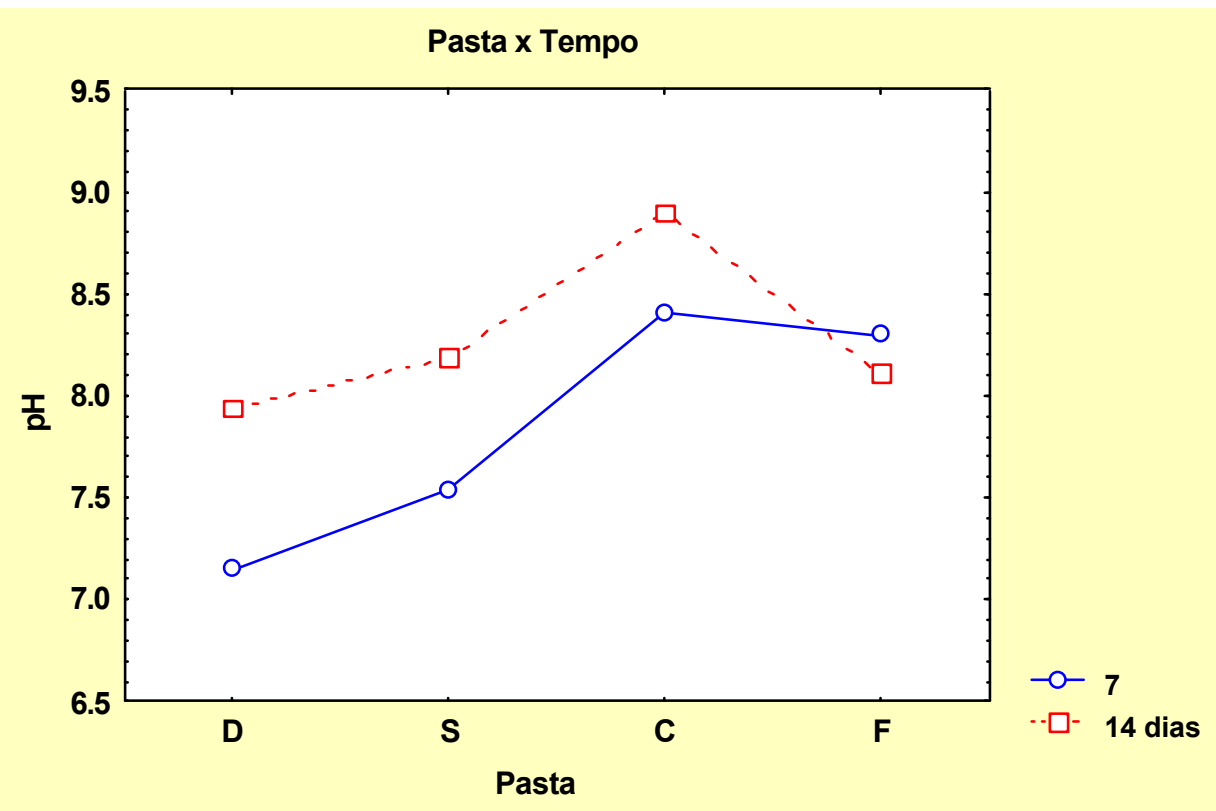

Figura 9 - alteração do pH em função do tipo de pasta (subgrupo 1 - D, subgrupo 2 - S, subgrupo 3 - C e subgrupo $4-F$ ) e o tempo (7 e 14 dias).

Tabela 5 - Análise de variância ANOVA

\begin{tabular}{ccccccc}
\hline & \multicolumn{7}{c}{ 1-PASTA, 2-DENTE, 3-TEMPO } \\
& Efeito & Efeito & Erro & Erro & F & p-nível \\
\hline 1 & 3 & 6.180984 & 40 & 0.765403 & 8.07546 & 0.0000 \\
2 & 1 & 0.040421 & 40 & 0.765403 & 0.052811 & 0.9675 \\
3 & 1 & 2.566031 & 40 & 0.184592 & 13.90111 & 0.0000 \\
12 & 3 & 0.20487 & 40 & 0.765403 & 0.267662 & 0.9652 \\
13 & 3 & 1.270054 & 40 & 0.184592 & 6.880336 & 0.0007 \\
23 & 1 & 0.319293 & 40 & 0.184592 & 1.729724 & 0.1959 \\
123 & 3 & 0.372832 & 40 & 0.184592 & 2.019767 & 0.1265 \\
\hline
\end{tabular}

Quadros pintados de amarelo, interação significante.

Quadro 2 - Conjuntos de mesmo desempenho após o teste de comparação múltipla de Tukey (5\%).

\begin{tabular}{|c|c|c|c|c|}
\hline Pasta & $\mathrm{pH}$ (médio) & \multicolumn{3}{|c|}{ Conjuntos* $^{*}$} \\
\hline $\mathrm{D}$ & 7.5428 & $\mathrm{~A}$ & & \\
\hline $\mathrm{S}$ & 7.8608 & $\mathrm{~A}$ & $\mathrm{~B}$ & \\
\hline $\mathrm{F}$ & 8.2020 & & $\mathrm{~B}$ & $\mathrm{C}$ \\
\hline $\mathrm{C}$ & 8.6505 & & & $\mathrm{C}$ \\
\hline
\end{tabular}

* letras iguais na mesma coluna indicam que as médias não diferem estatisticamente 
Quadro 3 - Interação: Pasta x Tempo. (subgrupo 1 (D), subgrupo 2 (S), subgrupo 3 (C) e subgrupo 4 (F)), nos períodos de 7 e 14 dias Conjuntos de mesmo desempenho após o teste de comparação múltipla de Tukey (5\%)

\begin{tabular}{|l|c|c|c|c|c|c|}
\hline \multicolumn{1}{|c|}{ Interações } & $\mathrm{pH}$ (médio) & \multicolumn{5}{c|}{ Conjuntos* } \\
\hline $\mathrm{D} / 7 \mathrm{~d}$ & 7.1500 & $\mathrm{~A}$ & & & & \\
\hline $\mathrm{S} / 7 \mathrm{~d}$ & 7.5350 & & $\mathrm{~B}$ & & & \\
\hline $\mathrm{D} / 14 \mathrm{~d}$ & 7.9355 & & & $\mathrm{C}$ & & \\
\hline $\mathrm{S} / 14 \mathrm{~d}$ & 8.1865 & & & $\mathrm{C}$ & $\mathrm{D}$ & \\
\hline $\mathrm{F} / 14 \mathrm{~d}$ & 8.1080 & & & $\mathrm{C}$ & $\mathrm{D}$ & \\
\hline $\mathrm{F} / 7 \mathrm{~d}$ & 8.2960 & & & $\mathrm{C}$ & $\mathrm{D}$ & \\
\hline $\mathrm{C} / 7 \mathrm{~d}$ & 8.4075 & & & & $\mathrm{D}$ & \\
\hline $\mathrm{C} / 14 \mathrm{~d}$ & 8.8935 & & & & & $\mathrm{E}$ \\
\hline
\end{tabular}

* letras iguais na mesma coluna indicam que as médias não diferem estatisticamente 


\section{Análise Estatística dos Dados de liberação de íons cálcio}

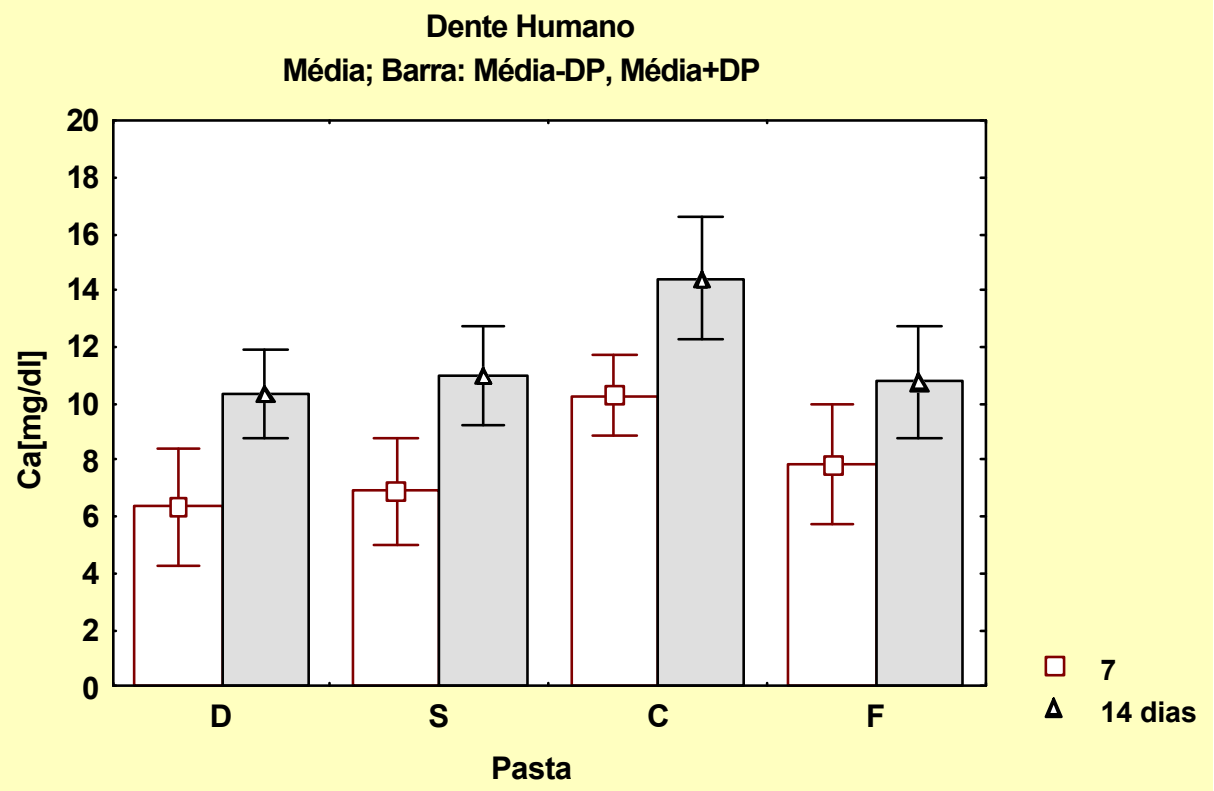

Figura 10 - Valores médios de liberação de cálcio aos 7 e 14 dias para os dentes humanos; subgrupo $1-\mathrm{D}$, subgrupo $2-\mathrm{S}$, subgrupo 3 - C e subgrupo $4-\mathrm{F}$.

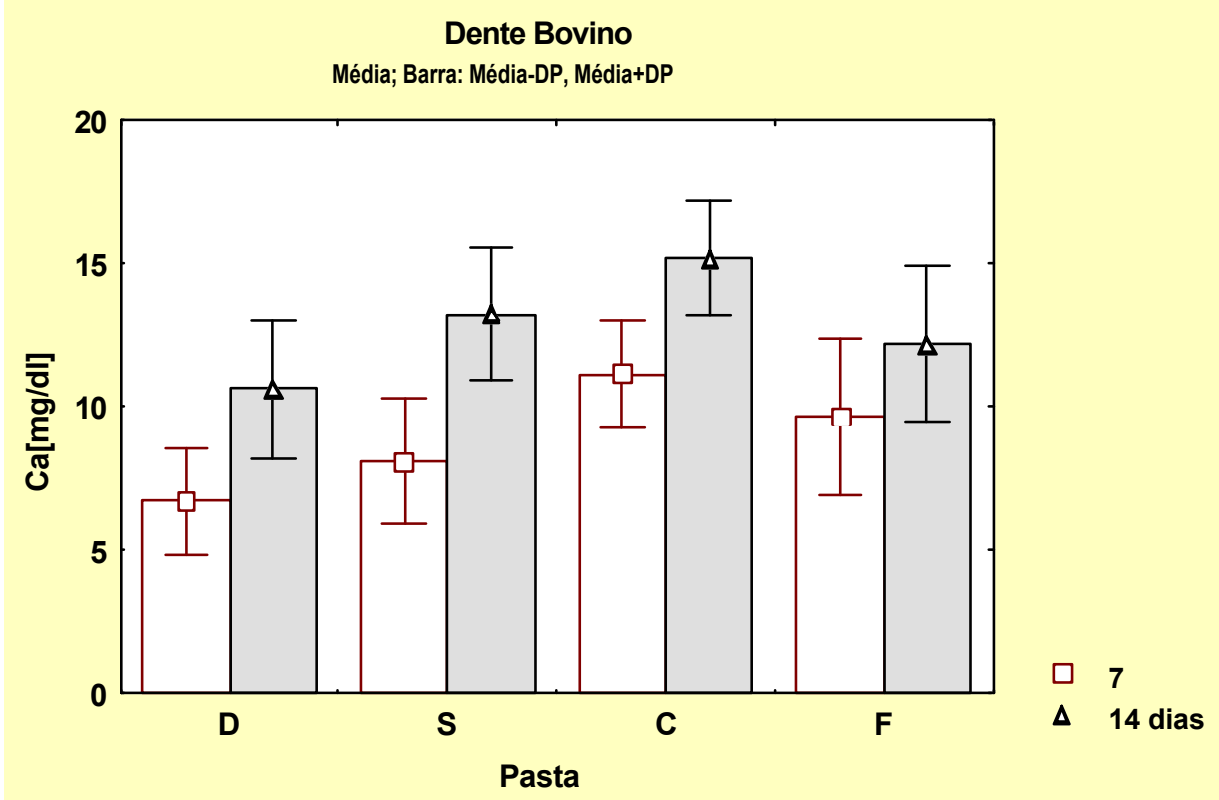

Figura 11 - Valores médios de liberação de cálcio aos 7 e 14 dias para os dentes bovinos; subgrupo 1 - D, subgrupo $2-\mathrm{S}$, subgrupo 3 - C e subgrupo $4-\mathrm{F}$. 


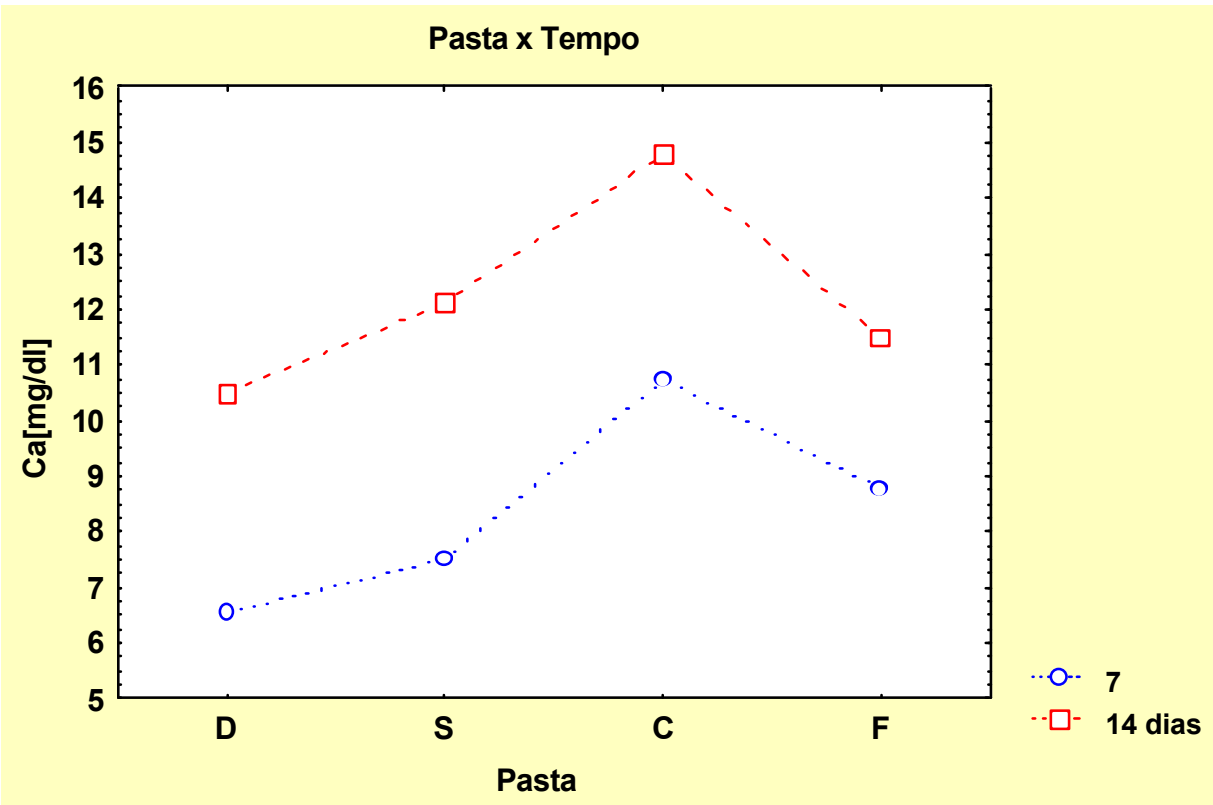

Figura 12 - liberação de cálcio em função do tipo de pasta (subgrupo 1 - D, subgrupo 2 - S, subgrupo 3 - C e subgrupo $4-F$ ) e o tempo (7 e 14 dias).

Tabela 6 - Análise de variância ANOVA

\begin{tabular}{lcccccc}
\hline \multicolumn{7}{c}{-PASTA, 2-DENTE, 3-TEMPO } \\
\hline & Efeito & Efeito & Erro & Erro & F & p-nível \\
1Pasta & 3 & 105.6676 & 40 & 7.533484 & 14.02639 & 0.0000 \\
2Dente & 1 & 97.88416 & 40 & 7.533484 & 12.99321 & 0.0073 \\
3Tempo & 1 & 489.4417 & 40 & 1.998642 & 244.8871 & 0.0000 \\
12 & 3 & 8.5617 & 40 & 7.533484 & 1.136486 & 0.5965 \\
13 & 3 & 9.969276 & 40 & 1.998642 & 4.988024 & 0.0228 \\
23 & 1 & 5.399225 & 40 & 1.998642 & 2.701446 & 0.7840 \\
123 & 3 & 3.527607 & 40 & 1.998642 & 1.765001 & 0.6460 \\
\hline
\end{tabular}

Quadros pintados de amarelo, interação significante.

Quadro 4 - Conjuntos de mesmo desempenho após o teste de comparação múltipla de Tukey (5\%).

\begin{tabular}{|c|c|c|c|c|}
\hline Pasta & $\begin{array}{c}\text { Cálcio } \\
\text { (médio) }\end{array}$ & \multicolumn{3}{|c|}{ Conjuntos* } \\
\hline D & 8.5165 & A & & \\
\hline S & 9.8125 & A & B & \\
\hline F & 10.127 & & B & C \\
\hline C & 12.768 & & & C \\
\hline
\end{tabular}

* letras iguais na mesma coluna indicam que as médias não diferem estatisticamente 
Quadro 5 - Interação: Pasta x Tempo. (subgrupo 1 (D), subgrupo 2 (S), subgrupo 3 (C) e subgrupo 4 (F)), nos períodos de 7 e 14 dias. Conjuntos de mesmo desempenho após o teste de comparação múltipla de Tukey (5\%)

\begin{tabular}{|l|c|c|c|c|c|c|}
\hline \multicolumn{1}{|c|}{ Interações } & $\begin{array}{c}\text { Cálcio mg/dl } \\
\text { (médias) }\end{array}$ & \multicolumn{5}{c|}{ Conjuntos } \\
\hline $\mathrm{D} / 7 \mathrm{~d}$ & 6.5430 & $\mathrm{~A}$ & & & & \\
\hline $\mathrm{S} / 7 \mathrm{~d}$ & 7.5040 & & $\mathrm{~B}$ & & & \\
\hline $\mathrm{F} / 7 \mathrm{~d}$ & 8.7720 & & $\mathrm{~B}$ & & & \\
\hline $\mathrm{D} / 14 \mathrm{~d}$ & 10.490 & & & $\mathrm{C}$ & & \\
\hline $\mathrm{C} / 7 \mathrm{~d}$ & 10.736 & & & $\mathrm{C}$ & & \\
\hline $\mathrm{F} / 14$ & 11.481 & & & $\mathrm{C}$ & $\mathrm{F}$ & \\
\hline $\mathrm{S} / 14 \mathrm{~d}$ & 12.121 & & & & $\mathrm{~F}$ & \\
\hline $\mathrm{C} / 14 \mathrm{~d}$ & 14.800 & & & & & $\mathrm{E}$ \\
\hline
\end{tabular}

* letras iguais na mesma coluna indicam que as médias não diferem estatisticamente 


\section{DISCUSSÃO}

Diversas metodologias podem ser empregadas para estudos sobre permeabilidade dentinária e pesquisas relativas à difusão de íons cálcio e hidroxila através da dentina radicular.

Os métodos mais comuns para verificação da difusão de íons hidroxila são: 1) utilização de evidenciadores de alteração no pH (ALAÇAM et al ${ }^{1}, 1998$; TRONSTAD et $\left.a l^{86}, 1981\right)$, como papel de tornasol, que indicam a alteração de pH pela mudança de cor; 2) uso de corantes associados às pastas (LEONARDO et $\left.a l^{53}, 1993\right) .3$ ) medidor de $\mathrm{pH}$ com eletrodo convencional (ANTHONY et $a l^{2}$, 1982; BELTES et al ${ }^{7}, 1997$; ÇALT et al ${ }^{12}$, 1999; FOSTER et $a l^{27}, 1993$; FUSS et $a l^{28}, 1996$; FUSS et $a l^{29} 1989$; HOSOYA et $a l^{46}, 2001$; SIMON et $\left.a l^{74}, 1995\right)$;

4) medidor de $\mathrm{pH}$ com eletrodo mais sofisticado e de tamanho reduzido (CÁRDENAS et $a l^{13}, 2001$; ESBERARD et $a l^{18}, 1996$; NERWICH et al ${ }^{61}$, 1993).

A utilização de evidenciadores dificulta a graduação exata do $\mathrm{pH}$ e a diferenciação entre os grupos. $\mathrm{O}$ uso de eletrodos convencionais acoplados a medidores de $\mathrm{pH}$, não retratam com fidelidade o $\mathrm{pH}$ da superfície dentinária, pois existe uma diluição dos íons hidroxila pela solução na qual o espécime ficou imerso e, quanto maior a diluição menor a fidelidade do teste. $\mathrm{O}$ melhor método para avaliação do pH é o uso de eletrodos de tamanho reduzido, que 
podem ser introduzidos na cavidade criada na superfície externa da raiz. Esse eletrodo permite verificar o $\mathrm{pH}$ diretamente na superfície radicular e nos terços apical, médio e cervical da raiz. Tem como inconvenientes o custo e a dificuldade de aquisição, além da fragilidade do material. Por isso adotamos o volume de $4 \mathrm{ml}$ de solução salina fisiológica como padrão para cada espécime; porém, para o efeito de comparação entre diferentes pastas, esse método é extremamente valioso, pois submete os espécimes à mesma condição, e fornece subsídios para comparação efetiva do comportamento de cada pasta. Além de ter custo relativamente baixo e ser de fácil aquisição;

Para a conservação dos dentes anterior a sua utilização, vários métodos podem ser empregados com essa finalidade. Neste estudo os dentes foram mantidos em solução aquosa de formol $10 \%$, para se preservar a estrutura colágena dos túbulos dentinários, seguido da imersão em solução salina (CÁRDENAS et $a l^{13}, 2001$; ESBERARD et $a l^{18}, 1996$; FUSS et $\left.a l^{29} 1989\right)$ até o momento de sua utilização. Para facilitar o preparo biomecânico e padronizar os espécimes, as coroas dos dentes foram removidas próximo à junção amelocementária, mantendo um comprimento de $15 \mathrm{~mm}$ para as raízes.

O preparo das cavidades foi realizado na superfície da face vestibular por ser a área de maior espessura das paredes dentinárias, pois as áreas proximais, por apresentarem paredes radiculares mais delgadas, as cavidades ficariam muito próximas à luz dos canais radiculares. O tamanho e a localização das 
cavidades foram baseados nos trabalhos de ALAÇAM et al ${ }^{1}$, (1998) e ÇALT et $a l^{12}$, (1999). A dimensão de $4 \mathrm{~mm}$ de comprimento por $2 \mathrm{~mm}$ de largura, foi escolhido por abranger os terços médio e apical. As pastas foram levadas ao interior dos canais radiculares com o auxílio de brocas Lentulo, considerando que estas proporcionam um melhor preenchimento do canal radicular (DEVEAUX et $a l^{16} 1992$ e SIGURDSSON et al ${ }^{73}$ 2000).

O EDTA foi utilizado para remoção da smear layer por ser a substância com maior comprovação científica de sua eficiência e segurança em sua aplicação (ALAÇAM et al ${ }^{1}$, 1998; CALERÓ et al, 1997 ; ÇALT et $a l^{12}, 1999$; CÁRDENAS et $a l^{13}, 2001$; ESBERARD et $a l^{18}$, 1996; FOSTER et al ${ }^{27}, 1993$; GUIGNES $e t a l^{36}, 1996$; LEONARDO et $a l^{53}, 1993$; NERWICH et at $t^{61}, 1993$; PÉCORA et $a l^{65}, 2000 ;$ SIMON et $\left.a l^{74}, 1995\right)$. O uso do EDTA promove uma eficiente desobstrução dos túbulos dentinários melhorando a limpeza do sistema de canais radiculares e da massa dentinária, diminuindo o número de bactérias, YOSHIDA et $a l^{3}$ (1995) e, principalmente facilitando a difusão iônica do hidróxido de cálcio através da dentina, FOSTER et $a l^{27}$ (1993). É grande o número de trabalhos recentes utilizando novas soluções (BARKHORDAR et al ${ }^{5}$, 1997; HOTTEL et $a l^{47}, 1999$ ), aplicação de lasers (PÉCORA et at ${ }^{65}, 2000$; TAKEDA et $\left.a l^{83}, 1999\right)$ para remoção da smear layer; estes novos materiais e aparelhos necessitam de mais estudos para sua aplicação clínica. 
A impermeabilização externa dos espécimes foi feita com uma camada de esmalte para unhas e uma camada de cera pegajosa, exceto na área do preparo na superfície radicular, para que a passagem de íons se desse exclusivamente pela área do preparo, não havendo interferência da abertura cervical, forame apical, delta apical e outras áreas anatômicas da raiz (ANTHONY et $a l^{2}$, 1982; ÇALT et $a l^{12}, 1999$; FOSTER et $a l^{27}, 1993$; HOSOYA et $a l^{46}, 2001$; SIMON et $a l^{74}$, 1995).

Os métodos mais comuns para verificação da liberação de íons cálcio através da dentina são realizados por espectrofotometria, que pode ser por absorção atômica (GOMES et $a l^{31}, 1996$; LEONARDO et $a l^{55}$, 1992) ou por luz (HOSOYA et $a l^{46}$, 2001) e como outra opção, pode-se utilizar microprocessadores para análise de íons (SIMON et $a l^{74}$, 1995). O teste considerado de maior precisão é o de espectrofotometria de absorção atômica, porém, o custo da aparelhagem é alto. O processamento por espectrofotometria à luz utilizado no presente estudo, também leva a resultados confiáveis. No entanto, durante o experimento é necessário precisão no ato de pipetar as soluções, uma vez que as alterações no volume destas soluções, alteram a concentração de íons cálcio e conseqüentemente a absorbância, podendo gerar leituras incoerentes nos resultados. Este experimento foi conduzido em espectrofotometria de luz UV e realizado em duplicata para cada espécime, por 
um profissional com bastante experiência na diluição das soluções, gerando resultados confiáveis.

A escolha da proposta do presente estudo deu-se devido à importância da alcalinização promovida pela aplicação intracanal de pastas à base de hidróxido de cálcio no sucesso do tratamento endodôntico, especialmente nas necropulpectomias com presença de lesões periapicais visíveis radiograficamente. Entretanto HAAPASALO et $a l^{37}$ (2000), relatam que a ação antimicrobiana de alguns medicamentos intracanal pode ser inativada pela dentina. ESTRELA et $a l^{22}$ (1999), verificaram que pastas à base de hidróxido de cálcio não tiveram efeito antimicrobiano in vitro, no interior dos túbulos dentinários, contra $S$. faecalis, $P$. aeruginosa, B. subtilis e $S$. aureus. Segundo os autores, a quantidade de íons hidroxila liberados no período de sete dias, não foi suficiente para alterar a integridade da membrana citoplasmática destes microrganismos. Autores como WANG; $\mathrm{HUME}^{90}$ (1988); FUSS et al ${ }^{29}$ (1988) e ÇALT et $a l^{12}$ (1999), acreditam que o efeito tampão da dentina pode impedir a penetração mais profunda de íons, no interior da mesma. Segundo os autores isso pode ocorrer quando doadores de prótons $\left(\mathrm{H}_{2} \mathrm{PO}_{4}^{-}, \mathrm{H}_{2} \mathrm{CO}_{3}\right.$ e $\left.\mathrm{HCO}_{3}{ }^{-}\right)$ presentes na camada hidratada da hidroxiapatita fornecem prótons adicionais para manter o pH inalterado, funcionando como um tampão. Os íons hidroxila também podem ser absorvidos por essa camada hidratada, diminuindo sua velocidade de difusão pelos túbulos dentinários. Ainda, sendo a solubilidade do 
hidróxido de cálcio em água, muito limitada, e a quantidade de íons hidroxila liberada insignificante, estes íons são neutralizados e acumulados nas paredes do canal radicular, impedindo a transferência de novos íons hidroxila. Porém, o que se vê na maioria dos trabalhos que avaliam as variações de pH, após o uso de hidróxido de cálcio, é que este medicamento é capaz de alcalinizar a massa dentinária radicular (ALAÇAM et al $1^{1}$, 1998; ANTHONY et al ${ }^{2}$, 1982; BELTES et $a l^{7}, 1997$; CÁRDENAS et $a l^{13}, 2001$; ESBERARD et $a l^{18}$, 1996; FOSTER et $a l^{27}, 1993$; FUSS et $a l^{28}, 1996$; FUSS et $a l^{29} 1989$; HOSOYA et $a l^{46}, 2001$; LEONARDO et $a t^{53}, 1993$; MIÑAMA et $a l^{58}, 2001$, NERWICH et at $t^{61}, 1993$; SIMON et $a l^{74}, 1995$; TRONSTAD et $\left.a l^{86}, 1981\right)$.

A opção por dentes bovinos, comparando os resultados com aqueles obtidos com dentes humanos, deu-se devido às limitações observadas na obtenção de dentes humanos para pesquisa na atualidade. Na presente pesquisa foram utilizados dentes bovinos e humanos, e constatou-se que para o fator $\mathrm{pH}$ não houve diferença estatisticamente significante entre os valores obtidos nos grupos bovinos e humanos. Porém na análise de liberação de íons cálcio os dentes bovinos apresentaram maior liberação de íons em relação aos dentes humanos (Tabelas 5 e 6). Isto ocorreu provavelmente devido ao maior calibre dos túbulos dentinários dos incisivos inferiores bovinos em relação aos premolares humanos. SCHMALZ et $a l^{71}$ (2001), analisando as características da permeabilidade dentinária de dentes humanos e bovinos in vitro, constataram 
que os dois tipos de dentes podem ser considerados similares. Estes resultados foram concordantes com o presente estudo quando se avaliou o $\mathrm{pH}$. Entretanto, em relação aos íons cálcio, is to não pôde ser verificado, provavelmente em função do maior calibre dos túbulos dentinários, apresentado pelos dentes bovinos. Os resultados observados em relação aos dentes bovinos mostram, especialmente para valores de $\mathrm{pH}$, que é possível utilizá-los na prática diária, viabilizando as pesquisas laboratoriais.

Avaliando as Tabelas 1, 2, 3 e 4, verificou-se que, tanto para os dentes humanos quanto bovinos, as médias de $\mathrm{pH}$ e liberação de íons cálcio foram maiores, quando utilizou-se o PMCC associado ao polietilenoglicol 400, como veículo do hidróxido de cálcio. As diferenças foram estatisticamente significantes quando comparadas aos subgrupos em que se utilizou detergente (grupo 1) e solução salina fisiológica (grupo 2). Estes resultados estão de acordo com ANTHONY et $a l^{2}$ (1982), que compararam os valores de $\mathrm{pH}$ de três veículos adicionados ao hidróxido de cálcio (cresatina, solução salina e PMCC), verificando maiores valores para o PMCC, provavelmente pela formação do sal paraclorofenolato de cálcio; SIMON et $a l^{74}$ (1995) que pesquisaram os efeitos no pH e na liberação de íons cálcio de quatro veículos adicionados ao hidróxido de cálcio (água destilada, solução salina, PMCC e propilenoglicol), também encontrando maiores valores para o PMCC; LEONARDO et $a t^{53}$ (1992), pesquisaram a capacidade de difusão de cinco curativos intracanal (PMCC sem 
hidróxido de cálcio, Pastas Calen, Calen PMCC e Calen + PMC e, Pasta aquosa) não encontrando diferenças estatísticas entre as pastas à base de hidróxido de cálcio, porém o PMCC sozinho, apresentou os piores resultados; ESBERARD et $a l^{18}$ (1996), compararam as alterações no $\mathrm{pH}$ radicular proporcionado por diferentes curativos à base de hidróxido de cálcio (hidróxido de cálcio + PMCC, hidróxido de cálcio + veículo aquoso e pasta Pulpodent) encontrando melhores resultados para o PMCC; FUSS et $a l^{28}$ (1996), avaliaram o $\mathrm{pH}$ de diferentes veículos associados ao hidróxido de cálcio (água, PMCC, Solvidont e as pastas Calxyl, Hydrocalcium) não encontrando diferenças entre os materiais e, CÁRDENAS et al ${ }^{13}$ (2001), que verificaram o $\mathrm{pH}$ radicular proporcionado por veículos associados ao hidróxido de cálcio (PMCC, tricresol formalina e água destilada), sem diferenças estatisticamente significantes entre os grupos. Porém, LEONARDO et $a l^{53}$ (1992) e FUSS et $a l^{28}$, (1996) encontraram valores de $\mathrm{pH}$ ligeiramente maiores para o veículo aquoso, em relação ao PMCC, mas sem diferenças estatisticamente significantes, além do que o método utilizado por esses autores foi o da penetração do corante associado à pasta, não diretamente relacionado a valores de $\mathrm{pH}$. LEONARDO et a $f^{55}$ (1992) verificaram que os valores de $\mathrm{pH}$ de diferentes pastas à base de hidróxido de cálcio (Calasept, Hidróxido de Cálcio associado a veículo aquoso, Calen e Calen PMCC), em diversos períodos de tempo, eram extremamente semelhantes. Porém, quanto à liberação de íons cálcio, a pasta Calen foi superior aos demais subgrupos. 
ALAÇAM et al ${ }^{1}$ (1998) encontraram resultados semelhantes para as alterações de $\mathrm{pH}$ entre pastas, à base de hidróxido de cálcio, veiculadas em água destilada e glicerina, no período de 12 dias. Segundo MURRAY et al $l^{59}$ (2000) outro fator que pode influenciar na dissociação iônica do hidróxido de cálcio é o tamanho da partícula que, quanto maior, menor será a dissociação.

Esperava-se, ao menos nos primeiros sete dias, um maior valor de $\mathrm{pH}$ e liberação de íons cálcio para a solução salina fisiológica em relação ao polietilenoglicol 400, por se tratar de um veículo aquoso e, teoricamente, proporcionar uma dissociação iônica mais rápida, tanto para os íons cálcio como para os íons hidroxila. O melhor comportamento do Calen PMCC pode ser explicado pelo melhor escoamento proporcionado pelos veículos viscosos, resultando em um melhor contato entre as paredes dentinárias e a pasta, gerando um melhor preenchimento do canal e conseqüentemente maior liberação iônica. Esse fato também poderia ser explicado pelo efeito tampão mais lento sofrido pelos veículos viscosos em relação aos veículos aquosos (LEONARDO et a ${ }^{53}$, 1993). Além disso, no presente trabalho, pôde-se observar que os veículos aquosos, principalmente a solução salina, secavam mais rápido, em relação aos veículos viscosos. Provavelmente devido à menor tensão superficial dos mesmos. Tal fato pode ser verificado no trabalho de HOSOYA et $a t^{46}$ (2001), no qual o aumento na proporção de água na pasta levava a uma maior liberação iônica. Confirmado pelas observações de ÖZCELIK et at $t^{63}$ (2000), que 
verificaram uma menor tensão superficial para os veículos aquosos (solução salina isotônica), em relação aos viscosos (glicerina). Também SAFAVI; NAKAYAMA $^{67}$ (2000) realizando um trabalho sobre a condutividade de diferentes veículos, ressaltam que os veículos aquosos proporcionam maior condutividade, em relação aos veículos viscosos.

VONGSAVAN et $a l^{88}$ (2000) relatam existir dificuldade na experimentação sobre permeabilidade dentinária, pois parece que o fluido dentinário in vitro, não tem o mesmo comportamento que in vivo, necessitanto mais estudos para se aproximar as duas situações.

Ainda com relação ao Calen PMCC, a formação de um composto chamado paraclorofenolato de cálcio, um sal formado pela combinação dos componentes da pasta, torna sua ação mais prolongada e mais estável (ANTHONY et $a l^{2}$, 1982; LEONARDO et $\left.a f^{53}, 1993\right)$.

O comportamento do grupo 4 (PMCF) foi aquém do esperado, considerando que o furacin, que é hidrossolúvel, quando adicionado ao paramonoclorofenol deveria apresentar melhores resultados, em relação à cânfora que não é hidrossolúvel. Esse melhor comportamento do Calen PMCC pode ter sido favorecido pela presença de óxido de zinco e colofônia em sua composição, pelo fato desses componentes melhorarem a consistência do medicamento. Constatou-se uma diminuição do pH do grupo 4 (F) dos sete para os 14 dias, ocorrência única em relação aos demais subgrupos. É possível que 
tenha ocorrido uma exaustão dos íons hidroxila após o período de 14 dias, fato esperado para os veículos aquosos, devido à rápida dissociação iônica proporcionada por estes.

Quanto aos períodos de avaliação (7 e 14 dias), em todos os subgrupos com exceção do grupo 4 (PMCF), os valores de pH e liberação de cálcio aumentaram do sétimo para o décimo quarto dia, mostrando que as pastas ainda tinham atividade de dissociação iônica. Isso pode ser comprovado pelos trabalhos de CÁRDENAS et $a l^{13}$ (2001) que verificaram que as trocas das pastas de hidróxido de cálcio, próximo ao trigésimo dia, proporcionaram uma melhor manutenção do pH elevado por longos períodos, e GOMES et al ${ }^{31}$ (1996) que verificaram que a troca das pastas de hidróxido de cálcio leva a uma maior liberação de íons cálcio.

A rápida liberação dos íons cálcio e hidroxila, proporcionada pela pastas veiculadas em polietilenoglicol 400, foi favorecida pela remoção da smear layer pelo uso do EDTA, que deixa a superfície radicular mais permeável, com menor número de resíduos e com os túbulos dentinários abertos e favorecendo a penetração e difusão dos íons no interior da massa dentinária. O fato foi comprovado, cientificamente, por FOSTER et $a l^{27}$ (1993), e GUIGNES et a ${ }^{36}$ (1996) que verificaram um aumento na permeabilidade dentinária após o uso do EDTA, superior ao uso do Ultra-som. Também ÇALT; SERPER ${ }^{11}$ (1999), verificaram que o EDTA foi à solução que permitiu a mais efetiva remoção dos 
resíduos de hidróxido de cálcio, do interior dos canais radiculares. Contudo, DEARDORF et $a l^{15}$ (1994) não verificaram influência da remoção da smear layer na difusão de íons cálcio através da dentina.

Os resultados deste trabalho mostram que o Calen PMCC pode ser a melhor opção para os casos de necrose pulpar com lesão periapical, com período de permanência de no mínimo 14 dias. Uma vez que para que a medicação chegue à superfície radicular, é necessário maior tempo devido à diminuição do calibre dos túbulos dentinários e da luz do canal em direção à superfície radicular (GARBEROGLIO; BRANNSTROM $^{30}, \quad$ 1976; TIDMARSH; ARROWSMITH $^{84}, 1989$; HOSOYA et $\left.a l^{46}, 2001\right)$. Também, deve-se levar em consideração o fato que as pastas ainda apresentavam atividade de dissociação iônica, ao final dos 14 dias. E segundo SJÖGREN et al (1991), o tempo inferior a 14 dias é insuficiente para que o hidróxido de cálcio tenha uma ação antimicrobiana efetiva, no interior dos túbulos dentinários. Além disso, este trabalho foi realizado no terço médio da raiz, e deve-se levar em consideração que o terço apical tem menor número de túbulos dentinários e menor calibre desses túbulos (CARRIGAN et $\left.a l^{14}, 1984\right)$, o que poderia dificultar neste terço, considerado o mais crítico, especialmente nos casos de haver reabsorção cementária apical. 
Também no grupo 1, utilizou-se um veículo aquoso, detergente laurilsulfato de sódio veiculado em metilparabeno, e a semelhança da solução salina, a difusão iônica foi menor quando comparado ao PMCC e PMCF.

Estes resultados são contrários ao esperado, pois o detergente tem baixa tensão superficial que poderia levar à melhor difusão do hidróxido de cálcio na massa dentinária que, de acordo com BARBOSA et al $t^{4}$, (1994) proporciona uma ação antimicrobiana mais rápida. Observa-se pelos resultados desta pesquisa que os veículos aquosos levaram à alcalinização menor do que os veículos viscosos, ação esta diferente do esperado, pois os veículos aquosos segundo LEONARDO et $a t^{53}$ (1993) permitem liberação iônica mais rápida. Isto mostra que mais estudos devem ser conduzidos, com o intuito de esclarecer o comportamento físico das pastas de hidróxido de cálcio, aliada às diferentes ações, especialmente antimicrobiana. 


\section{CONCLUSÕES}

Diante do que se propôs a examinar e de acordo com a metodologia aplicada, podemos concluir que:

- A pasta de hidróxido de cálcio associada ao PMCC (Calen PMCC) foi a que proporcionou estatisticamente os maiores valores de $\mathrm{pH}$ e de liberação de íons cálcio. Tanto para as raízes humanas quanto bovinas, seguido pelo PMCF e Solução Salina que se equivaleram e, finalizando pelo Detergente que foi estatisticamente inferior aos demais.

- As raízes humanas e bovinas tiveram o mesmo comportamento em relação aos diversos grupos; as alterações de $\mathrm{pH}$ foram semelhantes nas raízes humanas e bovinas; quanto à liberação de cálcio as raízes bovinas proporcionaram maiores valores, com diferença estatisticamente significante.

- Quanto ao período de permanência das pastas no interior do canal radicular, o período de 14 dias se mostrou mais promissor. 


\section{REFERÊNCIAS BIBLIOGRÁFICAS}

1. ALAÇAM, T., YOLDAS, O., GÜLEN, O. Dentin penetration of 2 calcium hydroxide combinations. Oral Surg. Oral Med. Oral Radiol. Endod., v.86, p.469-472, 1998.

2. ANTHONY, D.R., GORDON, T.M., DEL RIO, C.E. The Effect of three vehicles on the $\mathrm{pH}$ of calcium hydroxide. Oral Surg., v.54, n.5, p.560-565, Nov, 1982.

3. BARBOSA, C.A.M. et al. Evaluation of the antibacterial activities of calcium hydroxide, chlorexidine, and camphorated paramonochlorophenol as intracanal medicament. A clinical and laboratory study. J. Endod., v.23, n.5, p.297-300, May, 1997.

4. BARBOSA SV, SPANGBERG LS, ALMEIDA D. Low surface tension calcium hydroxide solution is an effective antiseptic. Int Endod J, v.27, n.1, p.6-10, Jan, 1994.

5. BARKHORDAR, R.A, et al. Removal of intracanal smear by doxycycline in vitro. Oral Surg. Oral Med. Oral Radiol. Endod., v.84, n.4, p.420-423, 1997.

6. BAUMGARTNER, J.C., FALKER, W.A. Bacteria in the apical $5 \mathrm{~mm}$ of infected root canals. J. Endod., v.17, n.8, p.380-383, Aug, 1991. 
7. BELTES, P.G, et al. In vitro release of hydroxyl ions from six types of calcium hydroxide no setting pastes. J. Endod., v.23, n.7, p.413-415, Jul, 1997.

8. BUCK, R. et al. Detoxification of endotoxin by endodontic irrigants and calcium hydroxide. J. Endod., v.27, n.5, p.325-27, May, 2001.

9. CALERÓ, F.D.S, et al. Ação química do EDTA sobre a dentina do canal radicular - análise com espectrofotometria de absorção atômica. Rev. FOB. v.5, n.3/4, p.65-68, jul./dez. 1997.

10. ÇALISKAN, M.K., TÜRKÜN, M., TÜRKÜN, L.S. Effect of calcium hydroxide as an intracanal dressing on apical leakage. Int. Endod. J., v.31, n.3, p.173-77, May, 1998.

11. ÇALT, S., SERPER, A. Dentinal tubule penetration of root canal sealers after root canal dressing with calcium hydroxide. J. Endod., v.25, n.6, p.431-33, Jun, 1999.

12. ÇALT, $\mathrm{S}$, et al. $\mathrm{pH}$ changes and calcium ion diffusion from calcium hydroxide dressing materials through root dentin. J. Endod., v.25, n.5, p.329-331, May, 1999.

13. CÁRDENAS, P.M.C., ESBERARD, R.M., SILVA, R.S.F. Influência das trocas de diferentes pastas de hidróxido de cálcio na alcalinização da superfície radicular de dentes humanos recém extraídos. J.B.E., v.1, n.4, p.47-53, jan/mar, 2001. 
14. CARRIGAN, P.J, et al. A scanning electron microscopic evaluation of human dentinal tubules according to age and location. J. Endod., v.10, n.8, p.359-363, Aug, 1984.

15. DEARDORF, K.A, et al. Effect of root canal treatments on dentin permeability. J. Endod., v.20, n.1, p.1-5, Jan, 1994.

16. DEVEAUX, E., DUFOUR, D., BONIFACE, B. Five methods of calcium hydroxide intracanal placement. Oral Surg. Oral Med. Oral Radiol. Endod., v.89, n.3, p.349-55, 2000.

17. DSTOMAT, A.J. et al. Effects of calcium hydroxide and tumor growth factor on collagen synthesis in subcultures I and V of osteoblasts. J. Endod., v.26, n.9, p.494-99, Sep, 2000.

18. ESBERARD, R.M., CARNES JR, D.L., DEL RIO, C.E. Changes in $\mathrm{pH}$ at the dentin surface in roots obturated with calcium hydroxide pastes. $\mathbf{J}$. Endod., v.22, n.8, p.402-405, Aug, 1996.

19. ESBERARD, R.M., CARNES JR, D.L., DEL RIO, C.E. pH Changes at the surface of root dentin when using root canal sealers containing calcium hydroxide. J. Endod., v.22, n.8, p.399-401, Aug, 1996.

20. ESTRELA, C. et al. Control of microorganisms in vitro by calcium hydroxide pastes. Int. Endod. J., v.34, n.5, p.341-45, Jul, 2001. 
21. ESTRELA, C. et al. Effect of the vehicle on the antimicrobial properties of the calcium hydroxide pastes. Braz. Dent. J., v.10, n.2, p.63-72, 1999.

22. ESTRELA, C. et al. Antimicrobial evaluation of calcium hydroxide in infected dentinal tubules. J. Endod., v.25, n.6; p.416-18, 1999.

23. ESTRELA, C. et al. In vitro determination of direct antimicrobial effect of calcium hydroxide. J. Endod., v.24, n.1; p.15-17, Jan, 1998.

24. FAVA, L.R.G. et al. Soluções de hidróxido de cálcio. J.B.E., v.1, n.3, p.66-70, out/nov/dez, 2000.

25. FAVA, L.R.G., SAUNDERS, W.P. Calcium hydroxide pastes:

classifications and clinical indications. Int. Endo. J., v.32, n.4, p.25782, Aug, 1999.

26. FOREMAN, P.C., BARNES, I.E. A review of calcium hydroxide. Int. Endod. J., v.23, p.283-297, 1990.

27. FOSTER, K.H., KULILD, J.C., WELLER, R.N. Effect of smear layer removal on the diffusion of calcium hydroxide through radicular dentin. J. Endod., v .19, n.3, p.136-140, Mar, 1993.

28. FUSS, Z, et al. Intracanal $\mathrm{pH}$ changes of calcium hydroxide pastes exposed to carbon dioxide in vitro. J. Endod., v.22, n.7, p.362-364, July, 1996. 
29. FUSS, Z., SZAJKIS, S., TAGGER, M. Tubular permeability to calcium hydroxide and to bleaching agents. J. Endod., v.15, n.8, p.362-364, Aug, 1989.

30. GARBEROGLIO, R., BRANNSTROM, M. Scanning electron microscopic investigation of human dentinal tubules. Arch. Oral Biol., v.21, n.6, p.355-63, 1976.

31. GOMES, I.C., et al. Diffusion of calcium through dentin. J. Endod., v.22, n.11, p.590-595, Nov, 1996.

32. GORDON, T.M., ALEXANDER, J.B. Influence on pH level of two calcium hydroxide root canal sealers in vitro. Oral Surg. Oral Med. Oral Radiol. Endod., v.61, p.624-628, 1986.

33. GORDON, T.M., RANLY, D.M., BOYAN, B.D. The effects of calcium hydroxide on bovine pulp tissue: variations in $\mathrm{pH}$ and calcium concentration. J. Endod., v.11, n.4, p.156-160, Apr, 1985.

34. GUIGAND, M, et al. Evaluation of the cytocompatibility of three endodontic materials. J. Endod., v.25, n.6, p.419-23, Jun, 1999.

35. GUIGAND, $\mathrm{M}$, et al. In vitro study of intradentinal calcium diffusion induced by two endodontics biomaterials. J. Endod., v.23, n.6, p.387-390, June, 1997. 
36. GUIGNES, P., FAURE, J., MAURETTE, A. Relationship between endodontic preparations and human dentin permeability measured in situ. J. Endod., v.22, n.2, p.60-67, Feb, 1996.

37. HAAPASALO, H.K. et al. Inactivation of local root canal medicaments by dentine: an in vitro study. Int. Endod. J., v.33, p.126-31, Mar, 2000.

38. HAN, G.Y., PARK, S.H., YOON, T.C. Antimicrobial activity of $\mathrm{Ca}(\mathrm{OH})_{2}$ containing pastes with Enterococcus faecalis in vitro. J. Endod., v.27, n.5, p.328-32, May, 2001.

39. HAMMARSTRÖM, L.E., et al. Effect of calcium hydroxide treatment on periodontal repair and root resorption. Endod. Dent. Traumatol., v.2, p.184-189, 1986.

40. HASSELGREN, G., OLSSON, B., CVEC, M. Effects of calcium hydroxide and sodium hypoclorite on the dissolution of necrotic porcine muscle tissue. J. Endod., v.14, n.3, p.125-127, Mar, 1988.

41. HOLLAND, R, et al. Apical leakage following root canal dressing with calcium hydroxide. Endod. Dent. Traumatol., v.11, p.261-263, 1995.

42. HOLLAND, R, et al. Endodontia: manual de Endodontia da Faculdade de Odontologia de Araçatuba. Araçatuba, Faculdade de Odontologia, 1979. 
43. HOLLAND, R. et al. Calcium hydroxide and corticosteroid-antibiotic association as dressings in cases of biopulpectomy. A comparative study in dogs'teeth. Braz. Dent. J., v.9, n.2, p.67-76, 1998.

44. HOLLAND, R. et al. Reaction of rat connective tissue to implanted dentin tube filled with mineral trioxide aggregate or calcium hydroxide. $\mathbf{J}$. Endod., v.25, n.3, p.161-65, Mar, 1999.

45. HOLLAND, R. et al. Reaction of rat connective tissue to implanted dentin tube filled with mineral trioxide aggregate, Portland cement or calcium hydroxide. Braz. Dent. J., v.12, n.1, p.3-8. 2001.

46. HOSOYA, N. et al. Calcium concentration and $\mathrm{pH}$ of the periapical environment after applying calcium hydroxide into root canals in vitro. J. Endod., v.27, n.5, p.343-46, May, 2001.

47. HOTTEL, T. L., EL-REFAI, N.Y., JONES, J.J. A comparison of the effects of three chelating agents on the root canals of extracted human teeth. J. Endod., v.25, n.11, p.716-717, Nov, 1999.

48. KEHOE, J.C. pH reversal following in vitro bleaching of pulpless teeth. J. Endod., v.13, n.1, p.6-9, Jan, 1987.

49. KONTAKIOTIS, E., NAKOU, M., GEORGOPOULOU, M. In vitro study of indirect action of calcium hydroxide on the anaerobic flora of the root canal. Int. Endod. J., v.28, p.285-289, 1995. 
50. KOULAOUZIDOU, E.A, et al. Cytotoxic effects of different concentrations of neutral and alkaline EDTA solutions used as root canal irrigants. J. Endod., v.25, n.1, p.21-23, Jan, 1999.

51. LAMBRIANIDIS, T., MARGELOS, J., BELTES, P. Removal efficiency of calcium hydroxide dressing from the root canal. J. Endod., v.25, n.2, p.85-88, Feb, 1999.

52. LARSEN, M.J., BINDSLEV, P.H., A laboratory study evaluating the release of hydroxyl ions from various calcium hydroxide products in narrow root canal-like tubes. Int. Endod. J., v.33, n.3, p.238-42, May, 2000.

53. LEONARDO, M.R, et al. Penetrabilidade do curativo de demora. R.G.O., v.41, n.4, p.199-203, jul/ago., 1993.

54. LEONARDO, M.R. et al. In vitro evaluation of antimicrobial activity of sealers and pastes used in endodontics. J. Endod., v.26, n.7, p.391-94, Jul, 2000.

55. LEONARDO, M.R, et al. Avaliação da alteração do pH e da liberação de íons de cálcio em produtos endodônticos a base de hidróxido de cálcio. R.G.O., v.40, n.1, p.69-72, jan/fev., 1992.

56. MARION, D, et al. Scanning electron microscopic study of odontoblasts and circumpulpal dentin in a human tooth. Oral Surg. Oral Med. Oral Radiol. Endod., v.72, p.473-78, 1991. 
57. McCORMICK, J.E., WEINE, F.S., MAGGIO, J.D. Tissue pH of developing periapical lesions in dogs. J. Endod., v.9, n.2, p.47-51, Feb, 1983.

58. MIÑANA, M., CARNES, D.L., WALKER, W.A. pH changes at the surface of root dentin after intracanal dressing with calcium oxide and calcium hydroxide. J. Endod., v.27, n.1, p.43-45, Jan, 2001.

59. MURRAY, P.E, et al. The influence of sample dimensions on hydroxil ion release from calcium hydroxide products. Endod. Dent. Traumatol., v.16, n.6, p.251-57, Dec, 2000.

60. NELSON FILHO, P, et al. Connective tissue responses to calcium hydroxide based root canal medicaments. Int. Endod. J., v.32, n.4, p.303-11, Aug, 1999.

61. NERWICH, A., FIGDOR, D., MESSER, H.H. pH changes in root dentin over a 4-week period following root canal dressing with calcium hydroxide. J. Endod., v.19, n.6, p.302-306, June, 1993.

62. O'CONNELL, M.S. et al. A comparative study of smear layer removal using different salts of EDTA. J. Endod., v.26, n.12, p.739-743, Dec, 2000.

63. ÖZCELIK, B., TASMAN, F., OGAN, C. A comparison of the surface tension of calcium hydroxide mixed with different vehicles. $\mathbf{J}$. Endod., v.26, n.9, p.500-02, Sep, 2000. 
64. PASHLEY, D.H, et al. Effects of the degree of tubule occluion on the permeability of human dentine in vitro. Arch. Oral. Biol., v.23, p.1127-1133, 1978.

65. PECORA, J.D. et al. Evaluation of dentin root canal permeability after instrumentation and Er:YAG laser application. Lasers in Surg. And Med., v.26, n.3, p.277-81, 2000.

66. RIVIERA, E.M., WILLIAMS, K. Placement of calcium hydroxide in simulated canals: comparison of glycerin versus water. J. Endod., v.20, n.9, p.445-448, Sep, 1994.

67. SAFAVI, K.E., NAKAYAMA, T.A. Influence of mixing vehicle on dissociation of calcium hydroxide in solution. J. Endod., v.26, n.11, p.649-51, Nov, 2000.

68. SAFAVI, K. E., NICHOLS, F.C. Alteration of biological properties of bacterial lipopolysaccharide by calcium hydroxide treatment. $\mathbf{J}$. Endod., v.20, n.3, p.127-29, Mar, 1994.

69. SAFAVI, K. E., NICHOLS, F.C. Effect of calcium hydroxide on bacterial lipopolysaccharide. J. Endod., v.19, n.2, p.76-78, Feb, 1993.

70. SCHÄFER, E., BEHAISSI, A.A. pH changes in root dentin after root canal dressing with gutta-percha points containing calcium hydroxide. J. Endod., v.26, n.11, p.665-67, Nov, 2000. 
71. SCHMALZ, G. et al. Permeability characteristics of bovine and human dentin under different pretratament conditions. J. Endod., v.27, n.1, p.23-30, Jan, 2001.

72. SEN, B.H., WESSELINK, P.R., TÜRKÜN, M. The smear layer: a phenomenon in root canal therapy. Int. Endod. J., v.28, p.14-148, 1995.

73. SIGURDSSON, A., STANCILL, R., MADISON, S. Intracanal placement of $\mathrm{Ca}(\mathrm{OH})_{2}$ : a comparison of techniques. J. Endod., v.18, n.8, p.367370, Aug, 1992.

74. SIMON, S.T., BHAT, K.S., FRANCIS, R. Effect of four vehicles on the $\mathrm{pH}$ of calcium hydroxide and release of calcium ion. Oral Surg. Oral Med. Oral Radiol. Endod., v.80, p.459-464, 1995.

75. SIQUEIRA, J.F., FRAGA, R.C. Influência da medicação intracanal com pastas à base de $\mathrm{Ca}(\mathrm{OH})_{2}$ no selamento apical - efeito do veículo. Rev. Bras. Odontol., v.52, n.4, p.46-8, jul./ago. 1995.

76. SIQUEIRA, J.F., LOPES, H.P. Hidróxido de cálcio em endodontia. Suposições X comprovação científica. R.B.O., v.54, n.4, p.186-93, jul/ago, 1997.

77. SIQUEIRA, J.F., LOPES, H.P. Mechanisms of antimicrobial activity of calcium hydroxide: a critical review. Int. Endod. J., v.32, n.5, p.36169, Sep, 1999. 
78. SIQUEIRA, J.F., LOPES, H.P., UZEDA, M. Recontamination of coronally unsealed root canals medicated with camphorated paramonochlorophenol or calcium hydroxide pastes after saliva challenge. J. Endod., v.24, n.1, p.11-14, Jan, 1998.

79. SJÖGREN, U, et al. The antimicrobial effect of calcium hydroxide as a sort-tem intracanal dressing. Int. Endod. J., v.24, p.119-125, 1991.

80. STUART, K.G, et al. The comparative antimicrobial effect of calcium hydroxide. Oral Surg. Oral Med. Oral Radiol. Endod., v.72, p.101104, 1991.

81. SUNDQVIST, G., JOHANSSON, E., SJÖGREN, U. Prevalence of blackpigmented bacteroides species in root canal infections. J. Endod., v.15, n.1, p.13-19, Jan, 1989.

82. TAGGER, M., TAGGER, E., KFIR, A. Release of calcium and hydroxyl ions from set endodontic sealers containing calcium hydroxide. $\mathbf{J}$. Endod., v.14, n.12, p.588-591, Dec, 1988.

83. TAKEDA, F.H, et al. A comparative study of the removal of smear layer by endodontic irrigants and two types of laser. Int. Endod. J., v.32, n.1, p.32-39, Jan, 1999.

84. TIDMARSH, B.G., ARROWSMITH, M.G. dentinal tubules at the root ends of apicected teeth: a scanning electron microscopic study. Int. Endod. J., v.22, p.184-189, 1989. 
85. TIMPAWAT, S., VONGSAVAN, N., MESSER, H.H. Effect of removal of the smear layer on apical microleakage. J. Endod., v.27, n.5, p.351-53, 2001.

86. TRONSTAD, L, et al. pH changes in dental tissues after root canal filling with calcium hydroxide. J. Endod., v.7, n.1, p.17-21, Jan, 1981.

87. TROPE, M., DELANO, O., ORSTAVIK, D. Endodontic treatment of teeth with apical periodontitis: single vs. multivisit treatment. J. Endod., v.25, n.5, p.345-50, May, 1999.

88. VONGSAVAN, N., MATTHEWS, R.W., MATTHEWS, B. The permeability of human dentine in vitro and in vivo. Arch. Oral. Biol., v.45, n.11, p.931-35, Nov, 2000.

89. WADACHI, R., ARAKI, K., SUDA, H. Effect of calcium hydroxide on the dissolution of soft tissue on the root canal wall. J. Endod., v.24, n.5, p.326-330, May, 1998.

90. WANG, J.D., HUME, W.R. Diffusion of hydrogen ion and hydroxyl ion from various sources through dentine. Int. Endod. J., v.21, p.1726, 1988.

91. WAKABAYASHI, $\mathrm{H}$, et al. Effect of calcium hydroxide paste dressing on uninstrumented root canal wall. J. Endod., v.21, n.11, p.543-545, 1995. 
92. WEIGER, R., ROSENDAHL, R., LÖST, C. Influence of calcium hydroxide intracanal dressings on the prognosis of teeth with endodontically induced periapical lesions. Int. Endod. J., v.33, n.3, p.219-26, May, 2000.

93. YOSHIDA, T, et al. Clinical evaluation of the efficacy of EDTA solution as an endodontic irrigant. J. Endod., v.21, n.12, p.592-593, Dec,1995. 


\section{ABSTRACT}

The purpose of this study was to do an " in vitro " evaluating the alterations of the $\mathrm{pH}$ and the liberation of calcium ions, after the intracanal use of calcium hydroxide pastes with different vehicles. In this study 92 single-rooted human and bovine teeth were used. The crowns of the teeth were removed a de root preparation was made in $1 \mathrm{~mm}$ short the foramen. Sodium hypochlorite 2,5\%, was used to irrigation, followed by final irrigation EDTA. In the medium third of each specimen, in the buccal surface, a external cavity was accomplished with $4 \mathrm{~mm}$ of length X $2 \mathrm{~mm}$ of width and $1 \mathrm{~mm}$ of depth. The roots were divided in two groups: 46 human and 46 bovine. Each group was subdivided in 4 subgroups in agreement with the vehicle to be used, subgroup 1: detergent; subgroup 2: saline; subgroup 3: polyetilenoglicol $400+$ camphorated paramonochlorophenol (Calen PMCC) and I group 4: polyetilenoglicol $400+$ furacin paramonochlorophenol (PMCF). To roots they were waterproof externally, except in the cavity. Each specimen was immersed in an individual vials containing $4 \mathrm{ml}$ of physiologic saline solution, maintained to $37^{\circ} \mathrm{C}$. The measurements of the $\mathrm{pH}$ and calcium liberation were made to the 7 and 14 days. The human and bovine roots allowed a similar behavior for the $\mathrm{pH}$ analysis and of the liberation of calcium. Calen PMCC had statistically better in all analyses, followed for PMCF and saline that was equal and last the detergent that was statistically worst. The period of 14 days was shown more appropriate, showing increase in the ionic liberation. 


\section{CERTIFICADO}

CERTIFICAMOS, que o protocolo $n^{\circ}$ 003/2002-PH/CEP, sobre "Avaliação da difusão dentinária de pastas de hidróxido de cálcio, com diferentes veículos, por meio de alterações no pH radicular e liberação de cálcio, em dentes humanos e bovinos", sob a responsabilidade de Carlos Henrique Ribeiro Camargo, está de acordo com os Princípios Éticos, seguindo diretrizes e normas regulamentadoras de pesquisa, envolvendo seres humanos, conforme Resoluçăo $n^{\circ}$ 196/96 do Conselho Nacional de Saúde e foi aprovado pelo Comitê de Ética em Pesquisa.

São José dos Campos, 19 de março de 2002.

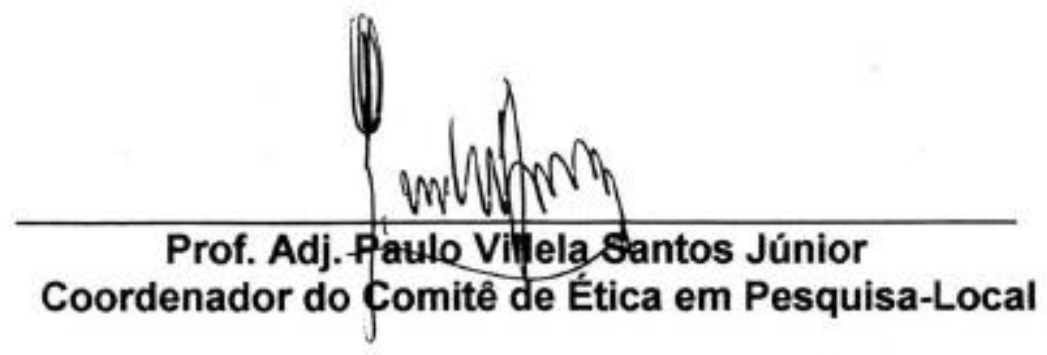

